\title{
28. RADIOLARIAN STRATIGRAPHY: LEG 16, DEEP SEA DRILLING PROJECT
}

\author{
Menno G. Dinkelman, School of Oceanography, Oregon State University, Corvallis, Oregon
}

\section{INTRODUCTION}

Radiolarians were found at all nine drilling sites of Leg 16 of the Deep Sea Drilling Project (Figure 1). Except for sediments of Paleocene and Lower Eocene age, the entire Cenozoic section was cored and sampled. In addition, at DSDP 163, sediment containing Upper Cretaceous radiolarians was recovered from the lower part of the hole. All sites were continuously cored except for DSDP 155.

Ten years ago stratigraphic correlation by means of radiolarians was virtually nonexistent. The past few years, however, have seen publication of several major papers on the subject (Riedel and Sanfilippo, 1970, 1971; Moore, 1971; Hays, 1965, 1971), and at present the use of radiolarians in stratigraphy, especially for the Cenozoic, has become a standard procedure. Figure 2 shows a generalized range chart for the radiolarian species studied in this report and the resulting zonation. This chart is a synthesis of the data obtained from all nine holes of DSDP Leg 16. For those parts of the Cenozoic section from which little sediment was recovered (particularly the Lower to Middle Miocene), reliance is placed on the work of Riedel and Sanfilippo (1970, 1971) and Moore (1971). The Leg 16 results show that the Upper Eocene "Thyrsocyrtis tetracantha" Zone cannot be maintained and should be eliminated. The earliest appearance of Thyrocyrtis bromia occurs before the first appearance of Thyrocyrtis tetracantha. This was also observed by Foreman (in press) in the
DSDP Leg 10 material. Thus the Thyrocyrtis bromia Zone now includes the former Thyrocyrtis tetracantha Zone, and the definition of the Thyrocyrtis bromia Zone is modified to accommodate this change. The Cannartus laticonus Zone of the Middle Miocene, eliminated by Riedel and Sanfilippo (1971) and resurrected by Moore (1971), is maintained in this report, since the data herein do not indicate that the upper part of the Dorcadospyris alata Zone overlaps the earliest occurrence of Cannartus (?) petterssoni. For the Quarternary, the zonation recently proposed by Nigrini (1971) has been adopted.

\section{DEFINITION OF CENOZOIC RADIOLARIAN ZONATION}

\section{Theocampe mongolfieri Zone}

Base: Earliest evolutionary appearance of Theocampe mongolfieri.

Top: Coincident with the base of the Thyrsocyrtis triacantha Zone.

Latest occurrences included: Podocyrtis aphorma, Theocotyle cryptocephala (?) nigriniae, Lithochytris archea, and Lamptonium (?) fabaeforme fabaeforme.

Earliest appearances included: Podocyrtis diamesa and Cycladophora hispida.

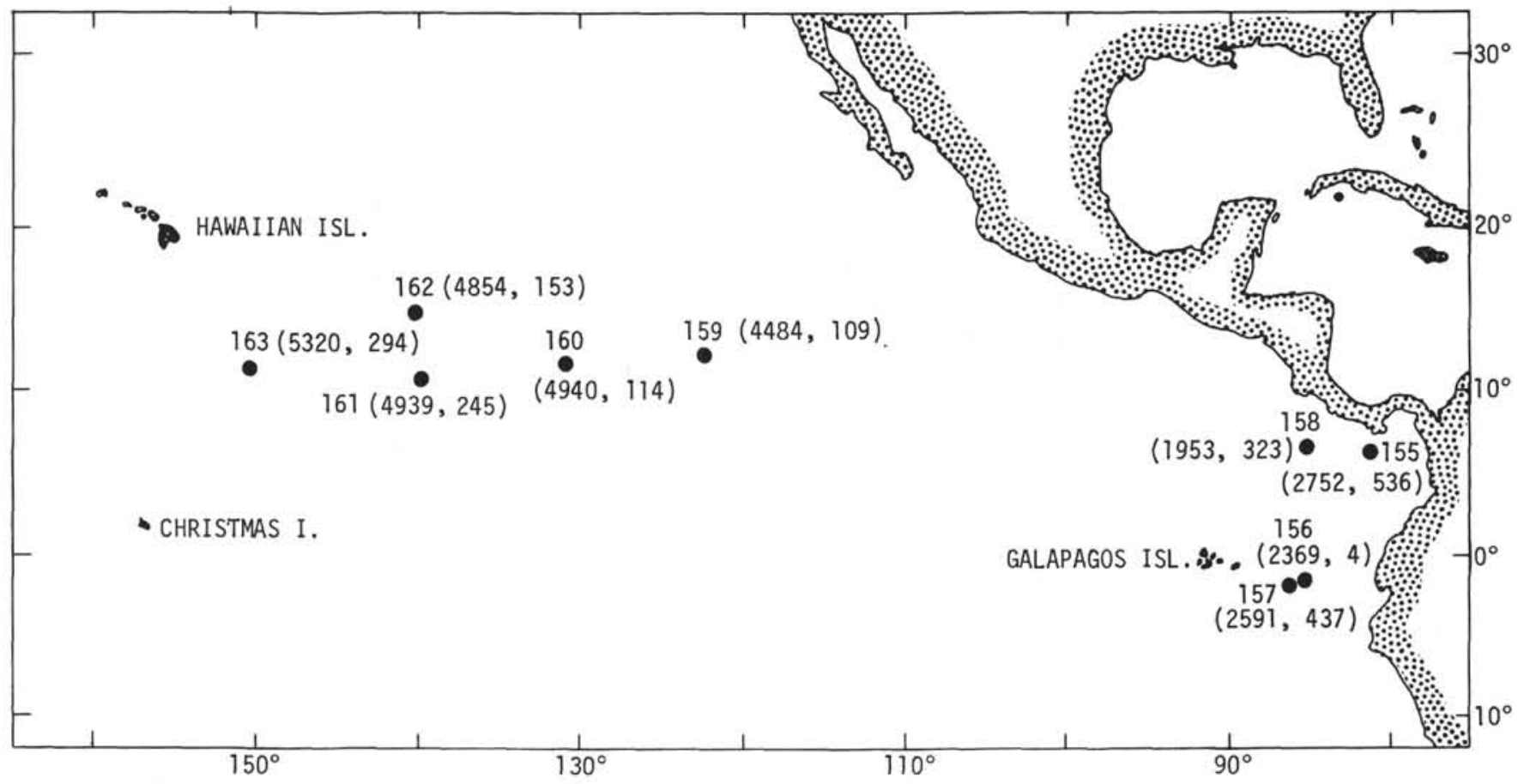

Figure 1. Location of drilling sites, Leg 16, Deep Sea Drilling Project. Site numbers are followed (in parentheses) by water depth and deepest drilling penetration (in meters). 


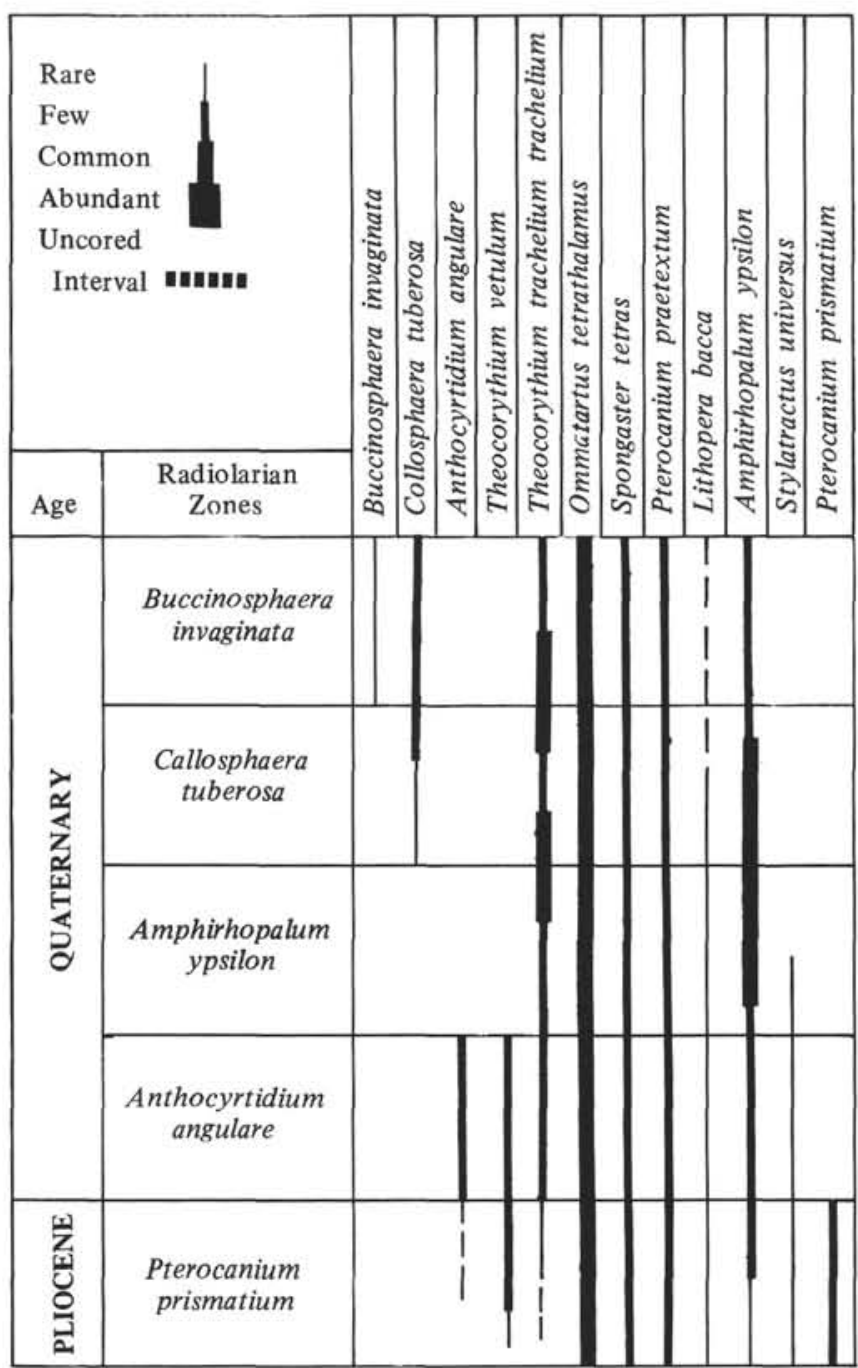

Figure 2. Generalized radiolarian range chart and zonation for DSDP Leg 16.

\section{Thyrsocyrtis triacantha Zone}

Base: Earliest appearance of Thyrsocyrtis triacantha, which is approximately synchronous with the earliest appearance of Eusyringium lagena (?) and latest occurrences of Triactis tripyramis tripyramis and Lamptonium fabaeforme (?) chaunothorax.

Top: Coincident with the base of the Podocyrtis ampla Zone.

Latest occurrences included: Lamptonium fabaeforme (?) constrictum, Theocorys anaclasta, Theocotyle cryptocephala cryptocephala (?), Thyrsocyrtis hirsuta robusta, and Phormocyrtis striata.

Earliest appearance included: Lithapium (?) anoectum.

\section{Podocyrtis ampla Zone}

Base: Earliest evolutionary appearance of Podocyrtis ampla which is approximately synchronous with the latest occurrence of Triactis tripyramis triangula. Zone.

Top: Coincident with the base of the Podocyrtis mitra
Latest occurrence included: Theocotyle venezuelensis, Podocyrtis diamesa, and Thyrsocyrtis hirsuta hirsuta.

Earliest appearance included: Eusyringium fistuligerum.

\section{Podocyrtis mitra Zone}

Base: Earliest evolutionary appearance of Podocyrtis mitra.

Top: Coincident with the base of the Podocyrtis chalara Zone.

Latest occurrences included: Podocyrtis sinuosa (?), $\mathrm{Li}$ thapium (?) plegmacantha, Eusyringium lagena (?), Lithapium (?) anoectum, and Podocyrtis ampla.

Earliest appearances included: Sethochytris triconiscus (?) and Lithapium(?) mitra(?).

Total range included: Podocyrtis trachodes.

\section{Podocyrtis chalara Zone}

Base: Earliest evolutionary appearance of Podocyrtis chalara.

Top: Coincident with the base of the Podocyrtis goetheana Zone.

\section{Podocyrtis goetheana Zone}

Base: Earliest evolutionary appearance of Podocyrtis goetheana, which is approximately synchronous with the latest occurrence of Sethochytris triconiscus (?).

Top: Coincident with the base of the Thyrsocyrtis bromia Zone.

Latest occurrence included: Lithochytris vespertilio and Theocorys anapographa.

Earliest appearances included: Lithocyclia aristotelis group and Cycladophora turris.

Thyrsocyrtis bromia Zone

Base: Earliest evolutionary appearance of Thyrsocyrtis bromia, which is approximately synchronous with the latest occurrence of Podocyrtis goetheana.

Top: Coincident with the base of the Theocyrtis tuberosa Zone.

Latest occurrence included: Podocyrtis papalis, Thyrsocyrtis bromia, Cycladophora turris, Thyrsocyrtis triacantha, Thyrsocyrtis rhizodon, Theocampe mongolfieri, Lithocyclia ocellus group, Sethochytris babylonis group, Podocyrtis mitra, Podocyrtis chalara, Theocotyle (?) ficus, Eusyringium fistuligerum, Lithapium (?) mitra, and $\mathrm{Cy}$ cladophora hispida.

Earliest appearances included: Artophormis gracilis, Theocyrtis tuberosa, Cyclampterium (?) milowi, and Dorcadospyris triceros.

Total range included: Thyrsocyrtis tetracantha and Lophocyrtis (?) jacchia.

\section{Theocyrtis tuberosa Zone}

Base: Earliest appearance of Lithocyclia angustum.

Top: Coincident with the base of the Theocyrtis annosa Zone.

Total ranges included: Dorcadospyris pseudopapilio, Centrobotrys gravida, Lithocyclia crux, Dorcadospyris spinosa, and Dorcadospyris quadripes. 


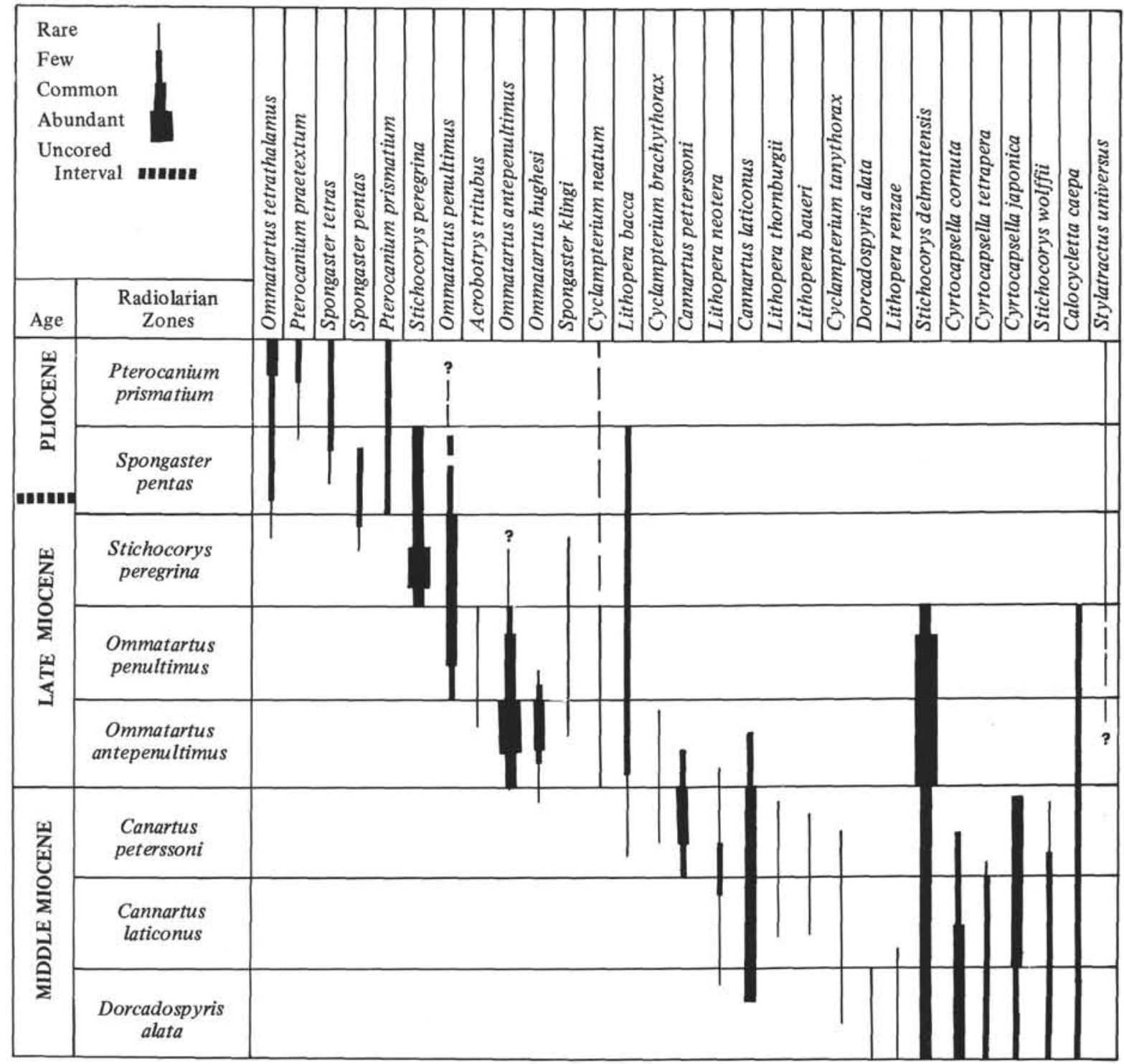

Figure 2. Continued.

\section{Theocyrtis annosa Zone}

Base: Earliest appearance of Theocyrtis annosa, which is approximately synchronous with the last occurrence of Theocyrtis tuberosa and with the earliest appearances of Dorcadospyris circulus, Dorcadospyris ateuchus, and Cannartus prismaticus.

Top: Coincident with the base of the Dorcadospyris papilio Zone.

Latest occurrences included: Dorcadospyris triceros, Lithocyclia angustum, and Cyclampterium (?) milowi.

Earliest appearances included: Cyclampterium pegetrum and Calocycletta parva.

\section{Dorcadospyris papilio Zone}

Base: Earliest appearance of Dorcadospyris papilio, which is approximately synchronous with the earliest appearance of $D$. riedeli.

Top: Coincident with the base of the Lychnocanoma bipes Zone.
Latest occurrences included: Dorcadospyris riedeli, Dorcadospyris circulus and Calocycletta parva.

Earliest appearances included: Dorcadospyris praeforcipata and Calocycletta robusta.

\section{Lychnocanoma bipes Zone}

Base: Earliest appearance of Lychnocanoma bipes.

Top: Coincident with the base of the Calocycletta virginis Zone.

Latest occurrences included: Dorcadospyris papilio and Artophormis gracilis.

Earliest appearances included: Cannartus tubarius, Cannartus sp. A. and Cyrtocapsella cornuta.

\section{Calocycletta virginis Zone}

Base: Earliest appearance of Calocycletta virginis, which is approximately synchronous with the earliest appearance of Cyrtocapsella tetrapera and Calocycletta serrata. 


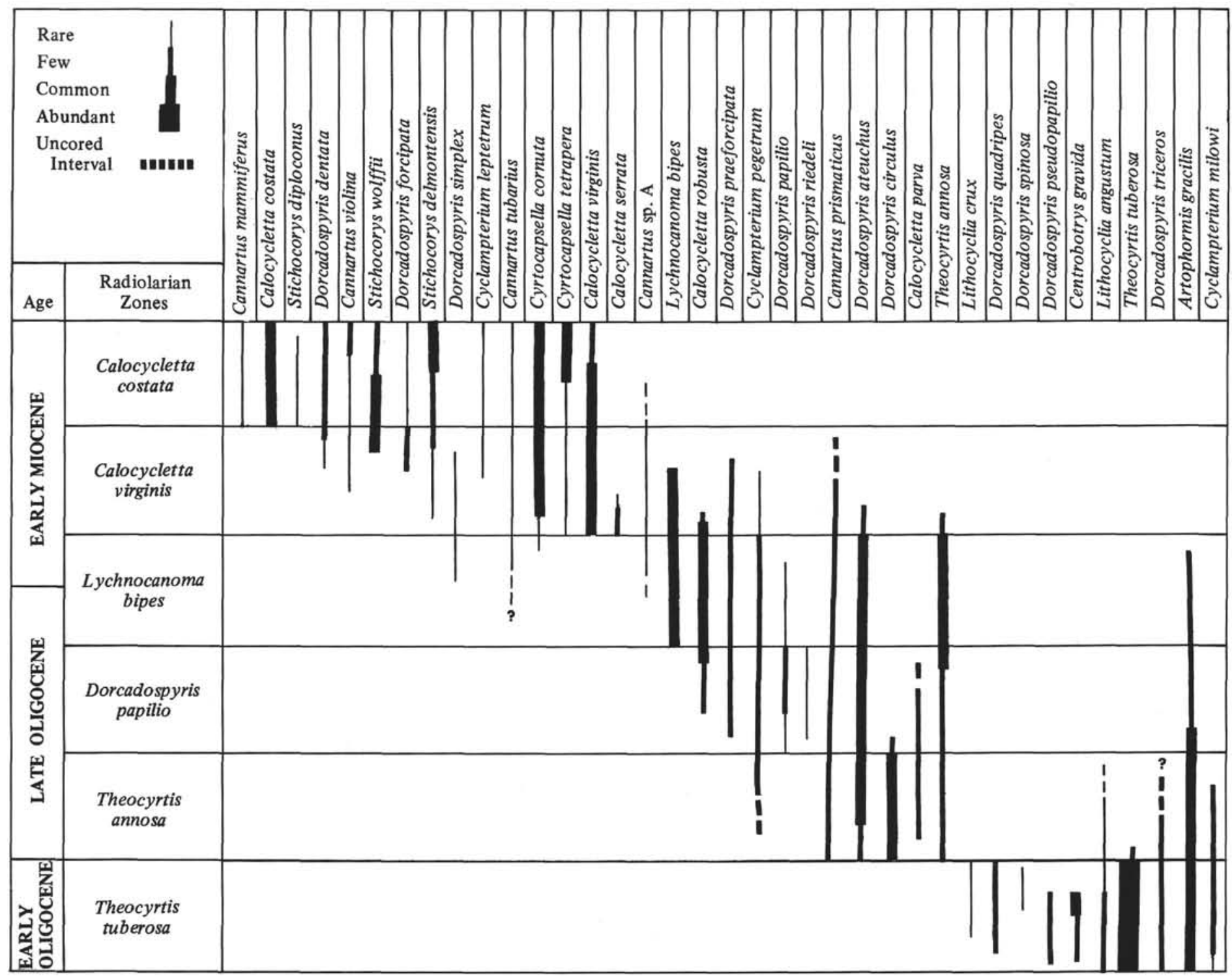

Figure 2. Continued.

Top: Coincident with the base of the Calocycletta costata Zone.

Latest occurrences included: Theocyrtis annosa, Dorcadospyris ateuchus, D. praeforcipata, Lychnocanoma bipes, Calocycletta robusta, and Cyclampterium (?) pegetrum.

Earliest appearances included: Dorcadospyris forcipata, D. dentata, Stichocorys delmontensis, $S$. wolffii, $C y$ clampterium (?) leptetrum, and Cannartus violina.

Total range included: Dorcadospyris simplex, Calocycletta serrata.

\section{Calocycletta costata Zone}

Base: Earliest evolutionary appearance of Calocycletta costata.

Top: Coincident with the base of the Dorcadospyris alata Zone.

Latest occurrence included: Cannartus prismaticus, Cannartus sp. A.
Earliest appearance included: perhaps Cannartus mammiferus.

Total range included: Stichocorys diploconus.

\section{Dorcadospyris alata Zone}

Base: Earliest evolutionary appearance of Dorcadospyris alata, which is approximately synchronous with the latest occurrence of $D$. forcipata, and with the earliest occurrence of Lithopera renzae.

Top: Coincident with the base of the Cannartus laticonus Zone.

Latest occurrence included: Dorcadospyris dentata, Cannartus mammiferus, Calocycletta virginis, C.costata, and Cyclampterium (?) leptetrum.

Earliest occurrences included: Cannartus laticonus, Calocycletta caepa, Cyclampterium (?) tanythorax, and $\mathrm{Li}$ thopera neotera.

Total range included: Dorcadospyris alata. 


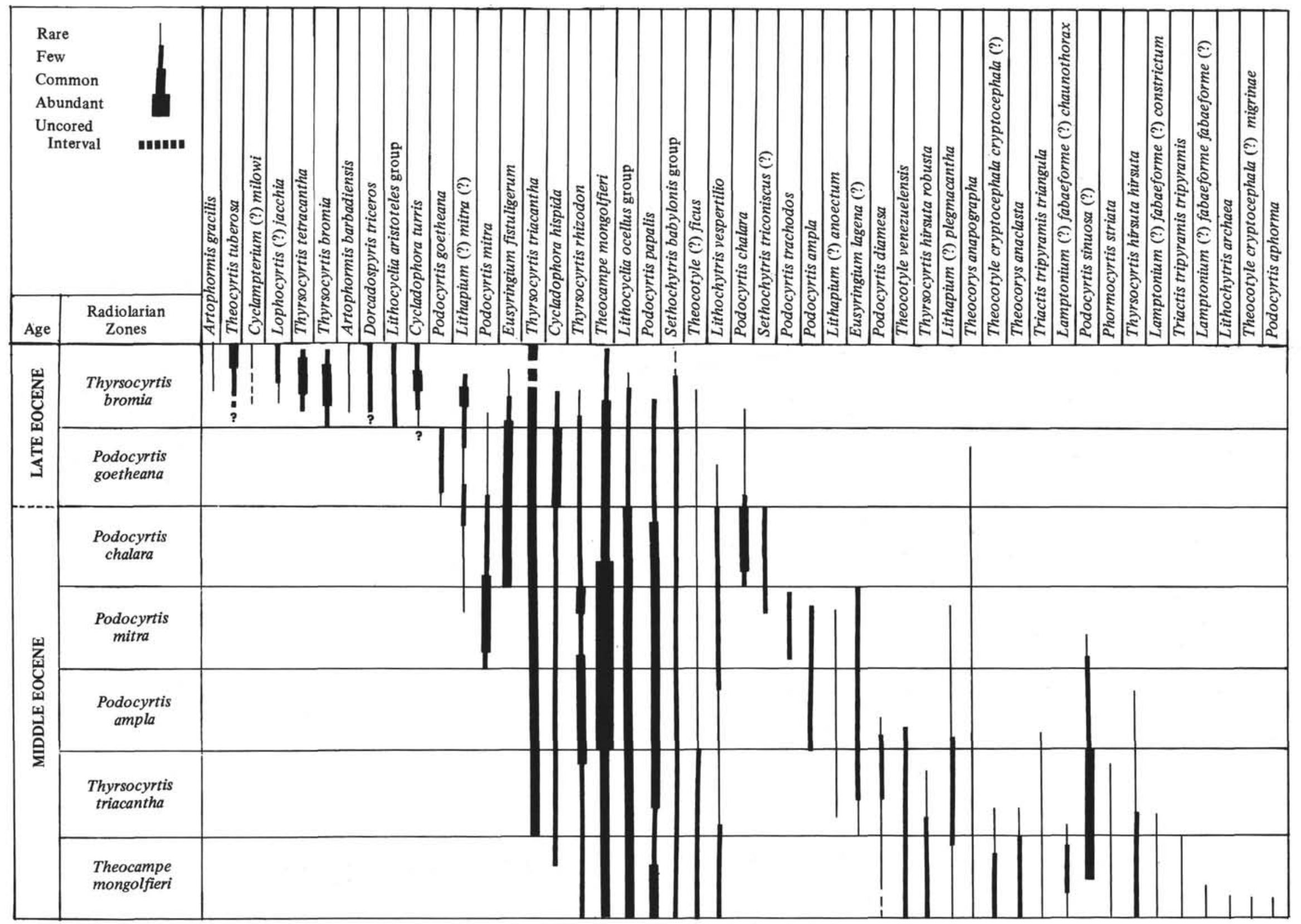




\section{Cannartus laticonus Zone}

Base: Latest occurrence of Dorcadospyris alata.

Top: Coincident with the base of the Cannartus (?) petterssoni Zone, which is approximately synchronous with the latest occurrence of Cyrtocapsella tetrapera.

Latest occurrence included: Lithopera renzae.

Earliest occurrence included: Lithopera thornburgii and Lithopera baueri.

\section{Cannartus (?) petterssoni Zone}

Base: Earliest evolutionary appearance of Cannartus petterssoni.

Top: Coincident with the base of the Ommatartus antepenultimus Zone.

Earliest appearances included: Cyclampterium (?) brachythorax, Lithopera bacca.

Latest occurrence included: Lithopera thornburgii, $L$. baueri, Stichocorys wolfii, Cyrtocapsella cornuta, C. japonica, Cyclampterium (?) tanythorax.

\section{Ommatartus antepenultimus Zone}

Base: Earliest evolutionary appearance of Ommatartus antepenultimus, which is approximately synchronous with the earliest occurrence of Ommatartus hughesi

Top: Coincident with the base of the Ommatartus penultimus Zone.

Latest occurrences included: Cannartus petterssoni, $C$. laticonus, Lithopera neotera, and Cyclampterium (?) brachythorax.

Earliest appearances included: Acrobotrys tritubus, Spongaster klingi, and Cyclampterium (?) neatum.

\section{Ommatartus penultimus Zone}

Base: Earliest evolutionary appearance of Ommatartus penultimus.

Top: Coincident with the base of the Stichocorys peregrina Zone.

Latest occurrence included: Ommatartus hughesi.

\section{Stichocorys peregrina Zone}

Base: Earliest evolutionary appearance of Stichocorys peregrina, which is approximately synchronous with the latest occurrences of $S$. delmontensis, Acrobotrys tritubus, and Calocycletta caepa. Zone.

Top: Coincident with the base of the Spongaster pentas

Latest occurrence included: Spongaster klingi, Ommatartus antepenultimus.

Earliest appearance included: Spongaster pentas, Stylatractus universus.

\section{Spongaster pentas Zone}

Base: Earliest appearance of Pterocanium prismatium.

Top: Coincident with the base of the Pterocanium prismatium Zone.

Latest occurrences included: Spongaster pentas and Ommatartus penultimus.

Earliest appearances included: Spongaster tetras, Pterocanium praetextum, and Ommatartus tetrathalamus.

\section{Pterocanium prismatium Zone}

Base: Latest occurrence of Stichocorys peregrina.

Top: Latest occurrence of Pterocanium prismatium.

Earliest appearances included: Theocorythium trachelium trachelium, Theocorythium vetulum, Anthocyrtidium angulare, and Amphirhopalum ypsilon.

Anthocyrtidium angulare Zone

Base: Latest occurrence of Pterocanium prismatium.

Top: Latest occurrence of Anthocyrtidium angulare, which is approximately synchronous with the latest occurrence of Theocorythium vetulum.

Amphirhopalum ypsilon Zone

Base: Latest occurrance of Anthocyrtidium cyrtidium angulare.

Top: Earliest appearance of Collosphaera tuberosa.

\section{Collosphaera tuberosa Zone}

Base: Earliest appearance of Collosphaera tuberosa.

Top: Earliest appearance of Buccinosphaera invaginata.

Buccinosphaera invaginata Zone (not sampled on Leg 16)

Base: Earliest appearance of Buccinosphaera invaginata.

\section{BIOSTRATIGRAPHY}

\section{DSDP $155\left(06^{\circ} 07.4^{\prime} \mathrm{N}, 8^{\circ} 02.6^{\prime} \mathrm{W}\right)$ - Figure 3}

Radiolaria are few in number and poorly preserved. They occur from about 434 meters to about 506 meters below the sea floor as well as in samples from 285, 371, and 384 meters.

In the top (bit) sample the presence of Amphirhopalum ypsilon, Theocorythium trachelium trachelium, Lamprocyclas maritales, in addition to Ommatartus tetrathalamus, Pterocanium praetextum, and Spongaster tetras indicate a Quaternary age. This is the only sample with poor to moderate preservation. The Spongaster pentas Zone is present in Samples 15(CC) and 14(CC) (285 and $371 \mathrm{~m}$ ). The Stichocorys peregrina Zone is present in sample $13(\mathrm{CC})(384 \mathrm{~m})$. The base of this zone lies at about 440 meters (between 155-1-3 and 155-1-5). The base of the Ommatartus penultimus Zone cannot be established with certainty but must lie at about 447 meters (between 155 1-5 and 155-2-5). The sediment from this interval consists of dolomitic limestone without significant siliceous biogenic debris. The alkaline nature of this environment may be responsible for the dissolution of all siliceous microfossils. Below 470 meters (at 155-4, CC) dissolution of the siliceous microfossils is so extensive that no reliable species identification can be made. A few samples from above this depth contain a moderately corroded assemblage of Ommatartus antepenultimus, Ommatartus hughesi, Stichocorys delmontenses, and Cannartus (?) petterssoni, indicating that the interval between 451 and 470 meters can be placed in the Ommatartus antepenultimus Zone. 


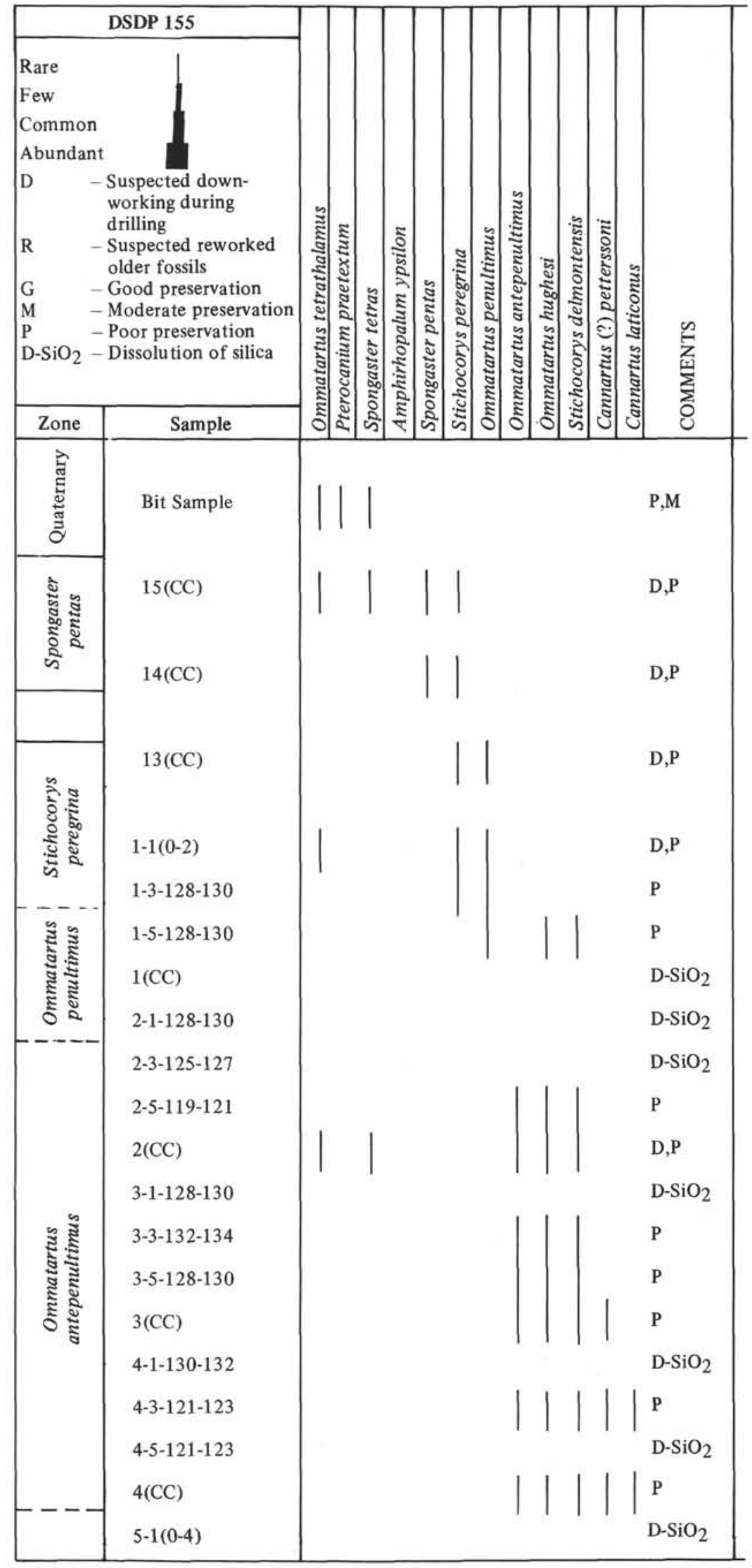

Figure 3. Radiolaria at DSDP 155. 
Contamination with Quaternary material has occurred in a few older samples. This is indicated by rare specimens of Lamprocyclas maritales, Anthocyrtidium ophirense, Theocorythium trachelium, and others, all of which are moderately well preserved. No evidence was found for older reworked material in any of the samples studied.

\section{DSDP $156\left(01^{\circ} 40.8^{\prime} \mathrm{S}, 8^{\circ} 24.1^{\prime} \mathrm{W}\right)$ - Figure 4}

Late Pleistocene radiolarians occur in all four samples examined from the single core retrieved at this site. The assemblages are diverse and well preserved. The common occurrences of Collosphaeridae, as well as of other members of the low latitude fauna, Ommatartus tetrathalamus, Pterocanium praetextum, Spongaster tetras, Amphirhopalum ypsilon, and Theocorythium trachelium trachelium, indicate a tropical environment.

The presence of Collosphaera tuberosa in all samples places the single core section in the Collosphaera tuberosa Zone of the upper Quaternary. Although reworked Upper Miocene and Pliocene nannoplankton species occur in the samples, no evidence of older reworked radiolarians was found. Diatoms are common in all samples from this core.

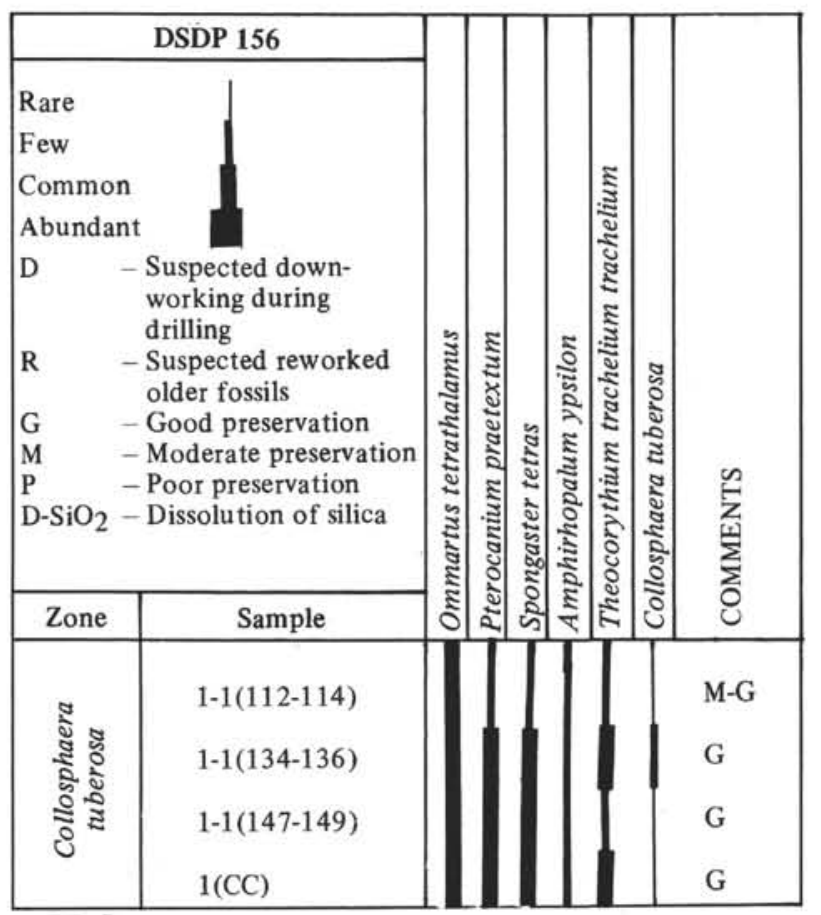

Figure 4. Radiolaria at DSDP 156.

\section{DSDP $157\left(01^{\circ} 45.7^{\prime} \mathrm{S}, 8^{\circ} 54.2^{\prime} \mathrm{W}\right)$ - Figure 5}

Radiolaria of rich, well-preserved, and diversified assemblages are found to a depth of 324 meters $(35, \mathrm{CC})$ below the sea floor. From 324 to 345 meters (between 36-1 and $38, \mathrm{CC}$ ) their numbers and the diversity decrease as the preservation declines. No siliceous microfossils are preserved in the cherty interval between 345 meters and the basement at 437 meters (from $38, \mathrm{CC}$ to $48, \mathrm{CC}$ ). The outlines of two radiolarians were recognized in the limestone associated with the chert in a thin section from the catcher sample of Core 44.
A complete late Tertiary and Pleistocene section was recovered at this site. Except for the uppermost Quaternary, all of the Pleistocene, Pliocene, and uppermost Miocene biostratigraphic zones described by Nigrini (1971) and Riedel and Sanfilippo (1970) were recognized. Reworking of Pliocene and late Miocene radiolarians is common throughout the section. It is especially pronounced in the Pliocene and Lower Pleistocene sections (from 6, CC to about $24, \mathrm{CC}$ ). This mixing leads to some uncertainty in the definition of zone boundaries in this interval.

Pterocanium prismatium and Spongaster pentas are always rare and occur only intermittently throughout their ranges. The base of the Spongaster pentas Zone is defined by the first appearance of Pterocanium prismatium. The erratic and rare occurrence of this species creates difficulties in placing both the base of this zone and the top of the Pterocanium prismatium Zone. A single specimen of Pterocanium prismatium in Core $30-3$ places the base of the Spongaster pentas Zone at 274 meters. The common occurrence of Stichocorys peregrina reworked into the Upper Pliocene sediments makes it difficult to establish with certainty the boundary between the Spongaster pentas and Pterocanium prismatium zones. It is placed here at about 170 meters (between 18-5 and 18, CC), because below this depth Stichocorys peregrina occurs as few to common specimens; above this depth it is rare.

Hole 157-A attempted to sample the uppermost Pleistocene because it appeared that this part of the section was missing at Hole 157. However, both holes were topped by the Collosphaera tuberosa Zone. In nearby piston cores the presence of the youngest radiolarian zone, the Buccinosphaera invaginata Zone, was established. The absence of this zone in both Hole 157 and Hole 157A is therefore due either to local bottom transport or to disturbance of the surface sediment by the drilling process. Diatoms are generally common to abundant throughout both sections of Hole 157 and 157A.

\section{DSDP $158\left(06^{\circ} 37.4^{\prime} \mathrm{N}, 8^{\circ} 14.2^{\prime} \mathrm{W}\right)-$ Figure 6}

Pleistocene to middle Miocene radiolarian assemblages are present in the cores at DSDP 158. Except for the top four cores where preservation is poor, the fauna is, in general, moderately well preserved.

Most of the late Tertiary and Quaternary radiolarian zones were sampled at this site. At the top of the section the Buccinosphaera invaginata Zone is missing, probably for reasons similar to those stated for DSDP 157 and 157A - local erosion or disturbance due to drilling. The Quaternary section is only about 30 meters thick (Cores 1 to 3 ) at this site. Preservation is poor in this part of the section and extensive reworking of Lower Pliocene and Upper Miocene radiolarians is evident. The reworked assemblage occasionally completely dominates the Quaternary fauna. One distinct hiatus occurs in the upper part of the section-in the Upper Pliocene and possibly the lowermost Quaternary. Between Sections 2 and 3 of Core 4, the fauna indicates a break in the record, as the Anthocyrtidium angulare Zone seems to lie directly on the Spongaster pentas Zone. It appears then that the Pterocanium prismatium Zone is missing entirely or, at least, in part, and it may be possible that the lowermost 


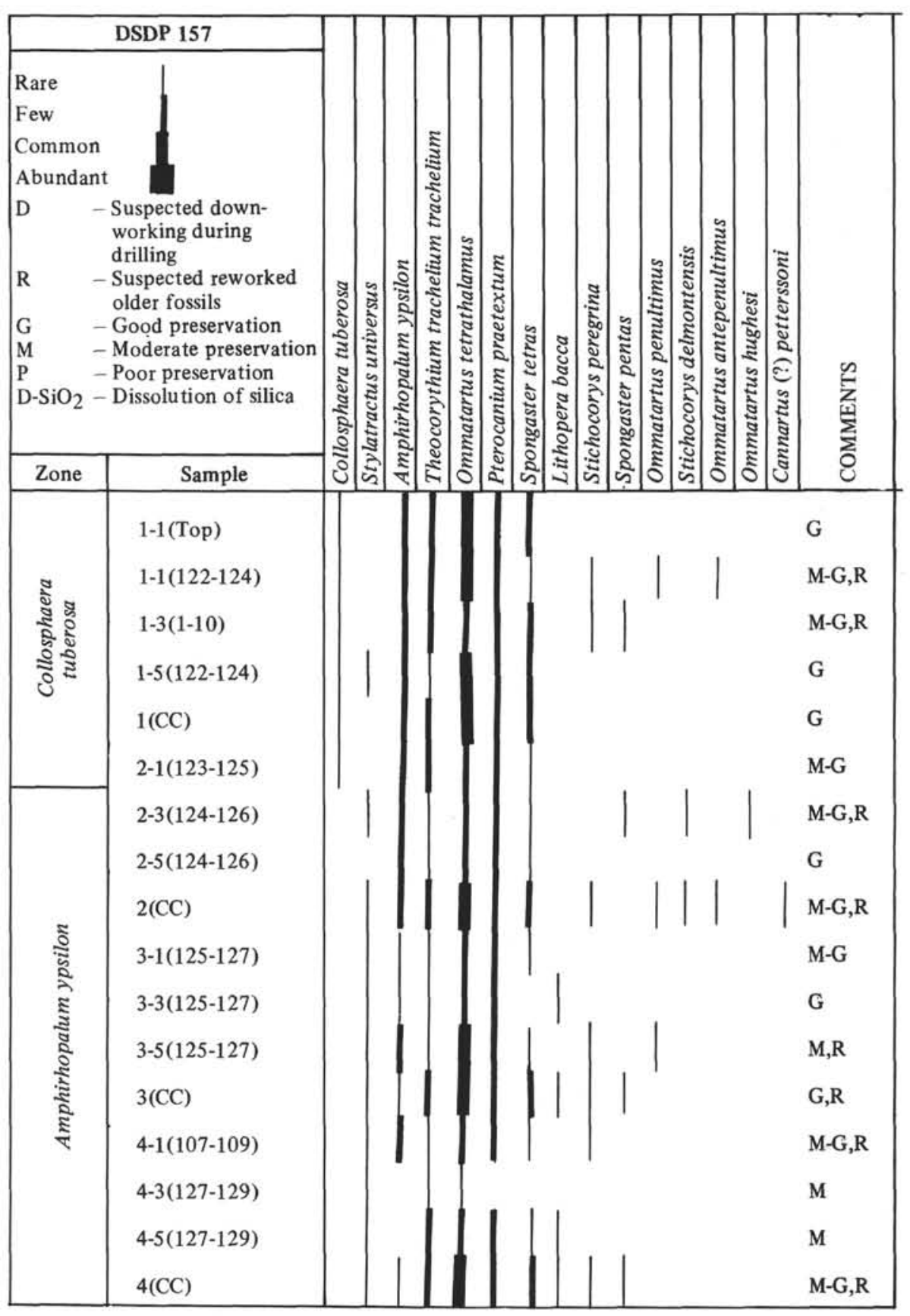

Figure 5. Radiolaria at DSDP 157.

well. Across this boundary there also occurs a marked change in preservation from poorly preserved above to moderately well preserved below.

The ambiguity concerning the boundaries of the Pterocanium prismatium and Spongaster pentas zones again arises as a result of the rare and erratic occurrences of Pterocanium prismatium, as well as of Spongaster pentas, throughout their ranges. In addition there is extensive reworking of older material which has affected the top 125 meters (to Core 14, CC) of sediment at this site.

Below the Spongaster pentas Zone all Upper and Middle Miocene zones are present to the Dorcadospyris alata Zone in which the hole bottoms.
The Cannartus (?) petterssoni Zone extends from 216 meters to 287 meters (Core 25 to Core 32). When correlation was attempted with the nannofossil and foraminiferal zones for this part of the section, the correlation of Berggren (in press) did not stand up.

Diatoms are present throughout the section. Below 126 meters they are generally more common than in the sediment above. They are particularly abundant in the interval between 270 meters to 297 meters and from 216 meters to 256 meters. The lower interval is characterized by a dominance of large centric diatoms, whereas in the higher interval pennate diatoms are ubiquitous. 


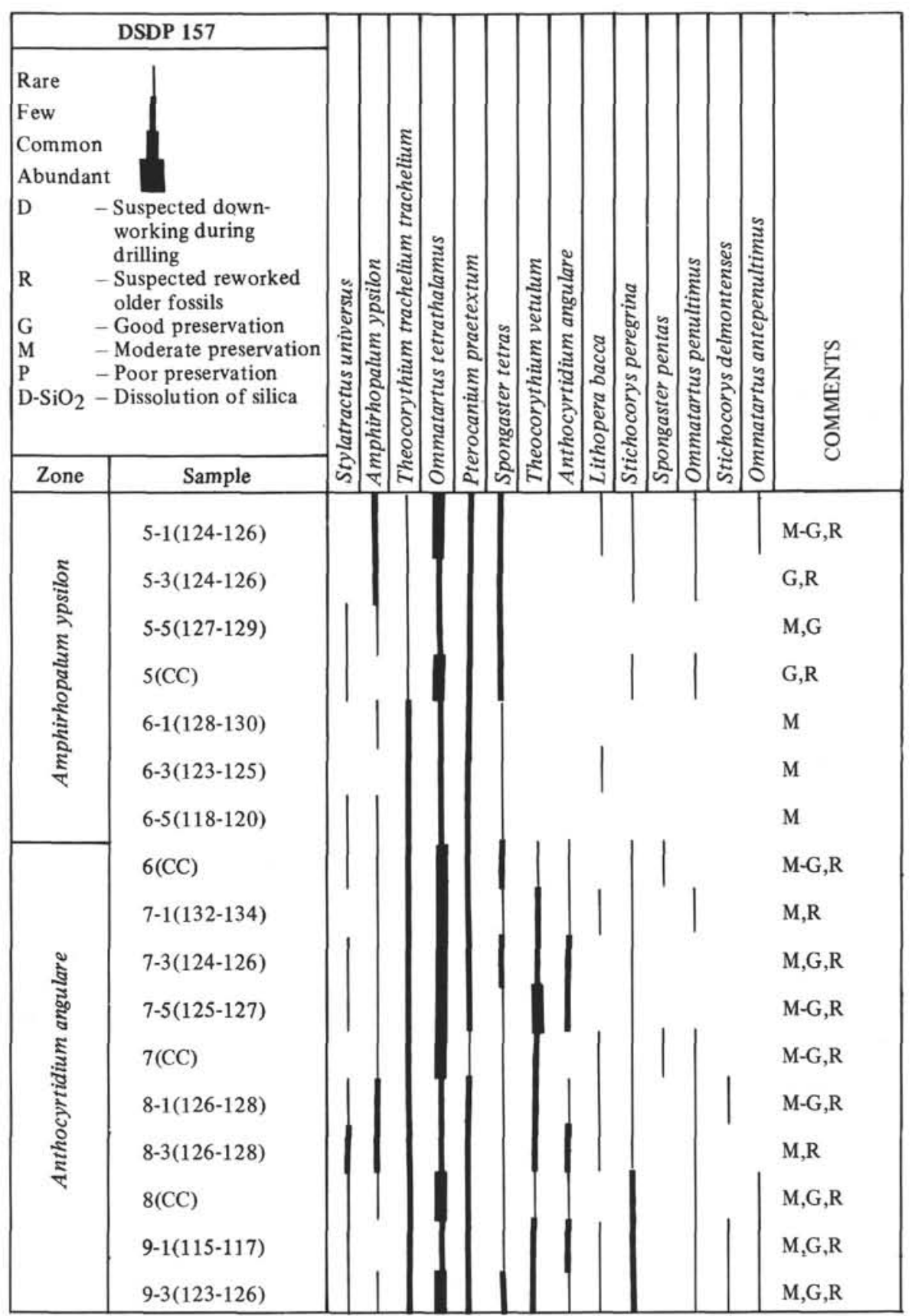

Figure 5. Continued.

\section{DSDP $159\left(12^{\circ} 19.9^{\prime} \mathrm{N}, 122^{\circ} 17.3^{\prime} \mathrm{W}\right)$ - Figure 7}

Radiolarians from Core 1 are moderately well preserved and occur in large numbers. The presence of $A n$ thocyrtidium angulare and Theocorythium vetulum indicates an early Quaternary age for this section. In Cores 2 and 3 radiolarians are few in number. Sponge spicules and spines and fragments of orosphaerid Radiolaria are most prominent in this section and represent the most solution-resistant silicious microfossils. A few severely corroded specimens of Ommatartus penultimus in Core 2, Section 4, and the presence of Ommatartus antepenultimus in the core catcher of Core 2 indicate these samples to belong to the zones of the same names.
All samples examined from Core 3 are devoid of siliceous microfossils. Core 4 can be placed in the Calocycletta costata Zone and Cores 5 and 6 both contain radiolarian assemblages of the Calocycletta virginis Zone. The assemblage is quite diversified and moderately well preserved in Core 4 , but both preservation and diversity decrease rapidly downward from Core 5 , Section 1 . Spines and fragments of mesh work of orosphaerid radiolarians are common throughout this section.

Throughout Cores 1 and 4 radiolarians are common to abundant, whereas in the interval between they occur only in a few layers. In Cores 5 and 6 their abundance decreases rapidly until they are completely absent from Core 7 on 


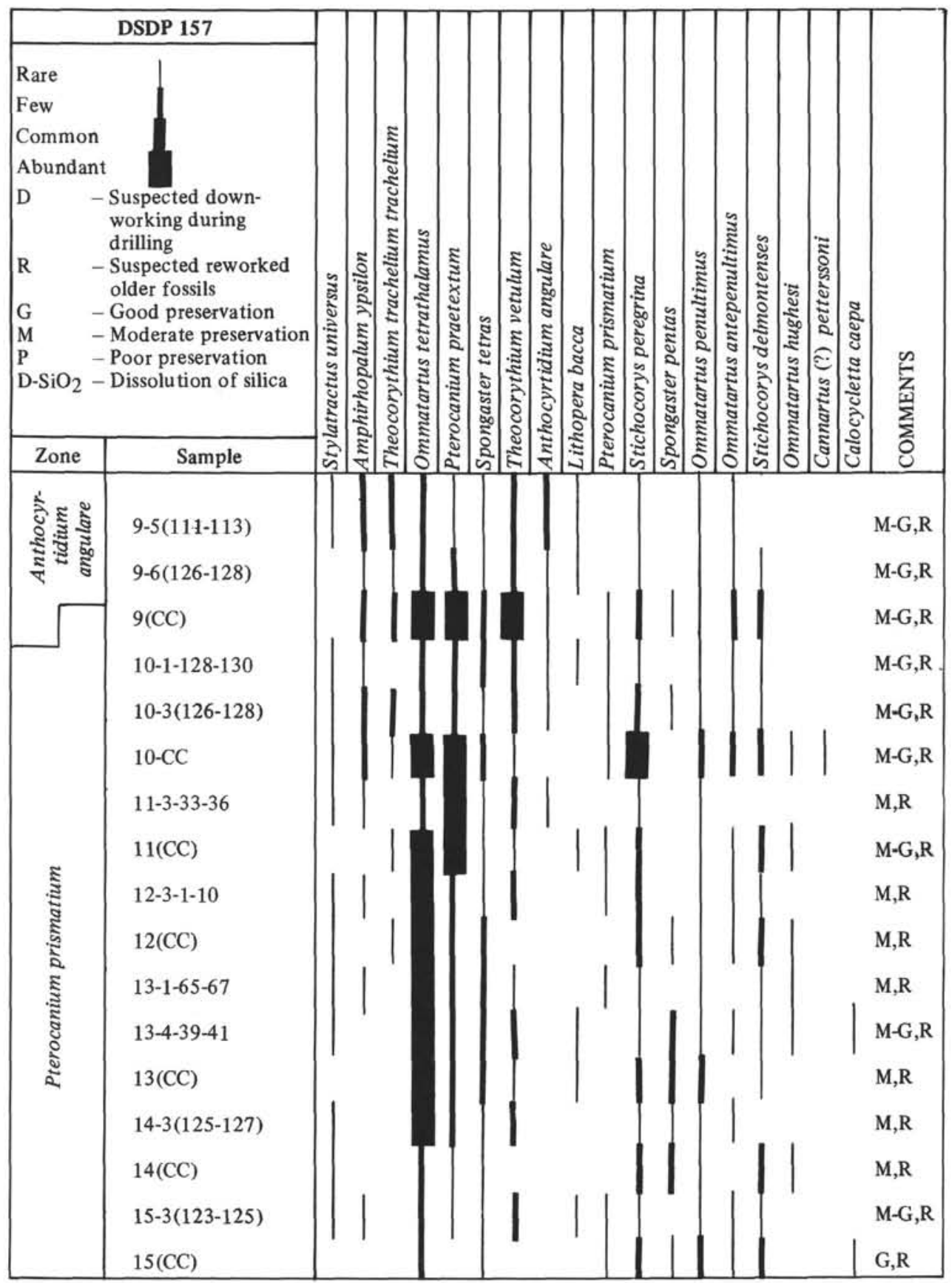

Figure 5. Continued.

down. Spines and fragments of orosphaerid radiolarians usually are an important component of the total radiolarian assemblage. No evidence was found for reworking in any of the samples examined.

Diatoms were observed only in the first core and are most common in the upper half of this core.

\section{DSDP $160\left(11^{\circ} 42.3^{\prime} \mathrm{N}, 1^{3} 0^{\circ} 52.8^{\prime} \mathrm{W}\right)$ - Figure 8}

half of Core 2 and the top of Core 3, radiolarians are present in all cores at this site. The abundance of the radiolarian tests preserved in the sediment generally increases with depth down the hole. A similar downward trend is observed for the preservation from poor at the top to good in the lower half of the hole. This change in the state of preservation occurs approximately at the same depth below which the assemblages no longer contain reworked older faunas.

The radiolarians from the top core are poorly preserved and few in number. The presence of Collosphaera tuberosa in the top two sections and of Amphirhopalum ypsilon in Section 3 indicates a middle to late Pleistocene age for the top 5 meters of the hole. A sample from Core 2, Section 5 contains a small number of radiolarians that suggest it belongs to the Calocycletta virginis Zone. Aside from this single sample, the interval between Core 1, Section 3 and Core 3 , Section 2 is barren of Radiolaria. Only a few spines and fragments of the solution-resistant orosphaerids were observed. 


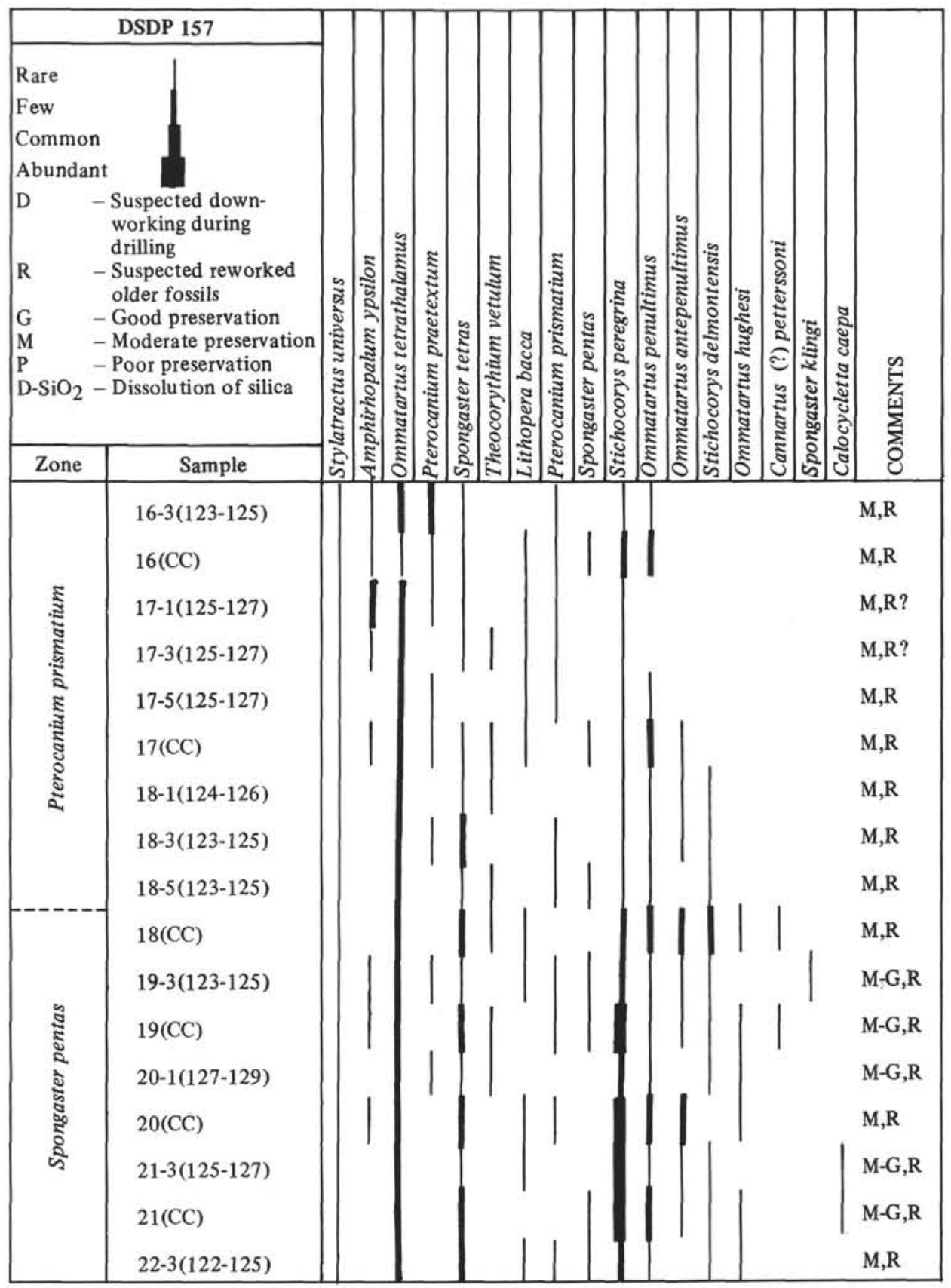

Figure 5. Continued.

The Lower Miocene Calocycletta virginis Zone of Cores 3 and 4 seems to lie discomformably over the Lychnocanoma bipes Zone of the Upper Oligocene in Core 5, with the upper part of the latter zone missing. Evidence for this is considered to be the presence of Dorcadospyris papilio in a sample from the top of Core 5, Section 1. Also, the state of preservation improves and the abundance increases across this boundary.

The lower boundary of the Lychnocanoma bipes Zone appears to be at 42 meters (Core 5, Section 4) where the nominate species first appears. A few specimens of $L y c h$ nocanoma bipes were observed in the catcher sample of Core 5, but because few Calocycletta virginis were found in the same sample, this presence is considered to be due to downward contamination by drilling.
Below 42 meters (Core 5, Section 4) all of the Oligocene zones (Moore, 1971) were sampled until the hole bottomed in the Theocyrtis tuberosa Zone at 114 meters (Core $13, \mathrm{CC})$.

\section{DSDP $161\left(10^{\circ} 40.3^{\prime} \mathrm{N}, 1^{\circ} 9^{\circ} 57.2^{\prime} \mathrm{W}\right)$ - Figure 9}

Radiolarians occur and are generally quite abundant throughout Holes 161 and 161A. In the upper part of the section they show signs of moderate solution, but lower down the hole preservation improves and the lower Oligocene and Eocene assemblages are generally well preserved. Spines and fragments of meshwork of orosphaerid radiolarians are quite common in the Miocene interval. Diatoms are present in samples from both the Oligocene and Miocene and are most abundant in samples from the Lower Oligocene. 


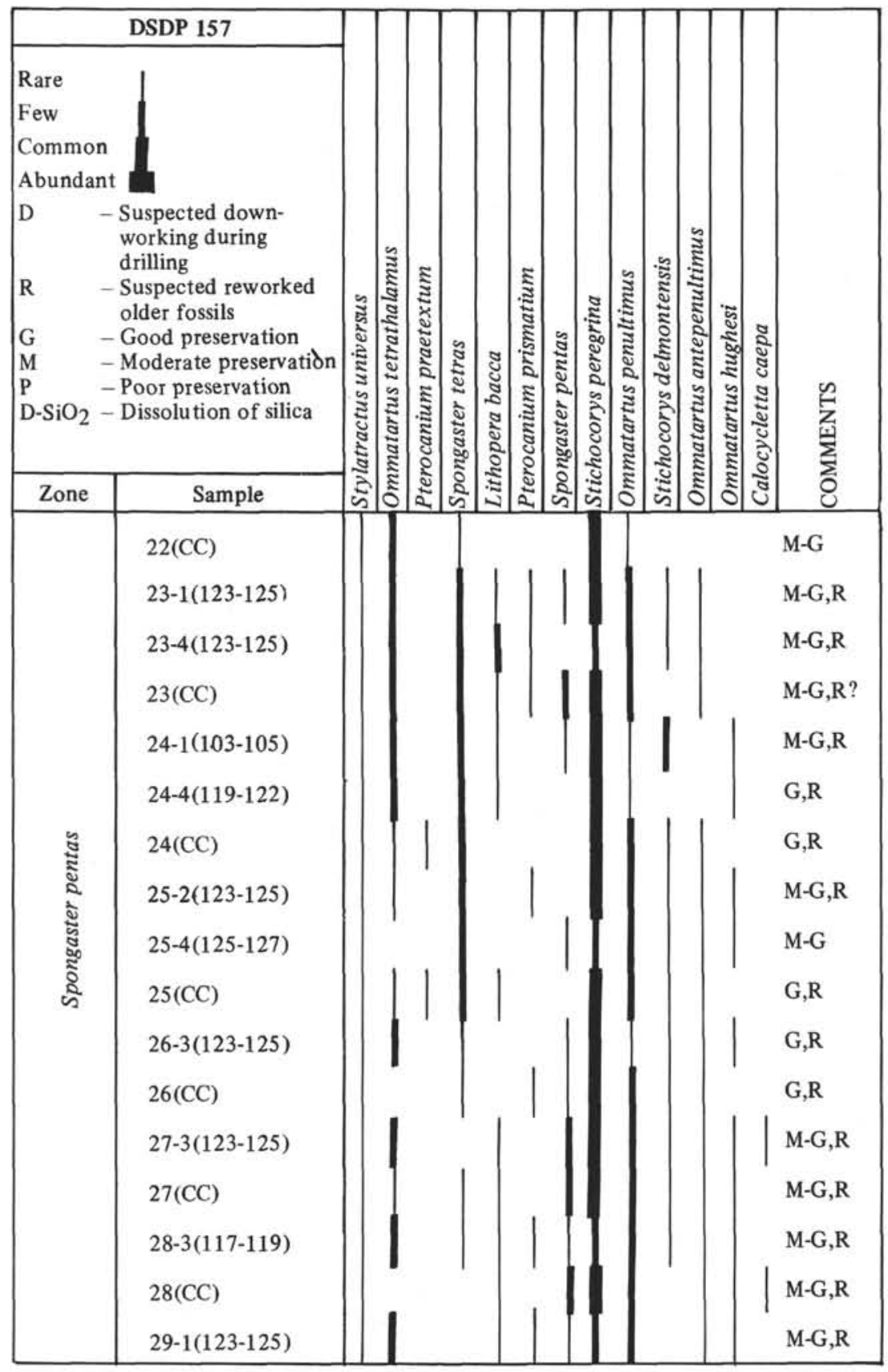

Figure 5. Continued.

The top sample of the first core taken at the sea floor (161-1) yielded abundant radiolarians of moderate preservation. The presence of a few, strongly corroded specimens of Spongaster tetras, Anthocyrtidium sp., and Ommatartus tetrathalamus suggests that a thin veneer of Quaternary sediment may be present on top of the early Miocene sediment. Aside from the frequent occurrence of Oligocene and Middle Eocene species, the most abundant microfossils in this sample are representative of the Calocycletta virginis Zone. From this point down to the upper Middle Eocene Podocyrtis mitra Zone in which Hole 161A bottomed, a nearly continuous section was cored and recovered. Although no clearly identifiable hiatuses could be observed, there may be some breaks in the record in the uppermost Oligocene and at the OligoceneEocene boundary (161A-9, CC). This boundary is marked by a sharp lithologic change from a white nannoplankton chalk to a brown radiolarite. Theocyrtis tuberosa, a species abundant in both the uppermost Eocene and Lower Oligocene, shows a marked change in morphology across this boundary. In a sample of the Eocene assemblage from the top of Core 10, the dominant form has a smooth thorax, while in the catcher of Core 9 nearly all specimens of Theocyrtis tuberosa show the pronounced knobby protuberances on its thorax. Although the same lithologic change and associated hiatus was observed on DSDP Leg 8 , at this site the lithologic change occurs between two cores, and it may be possible that any apparent hiatus is an artifact of sampling. 


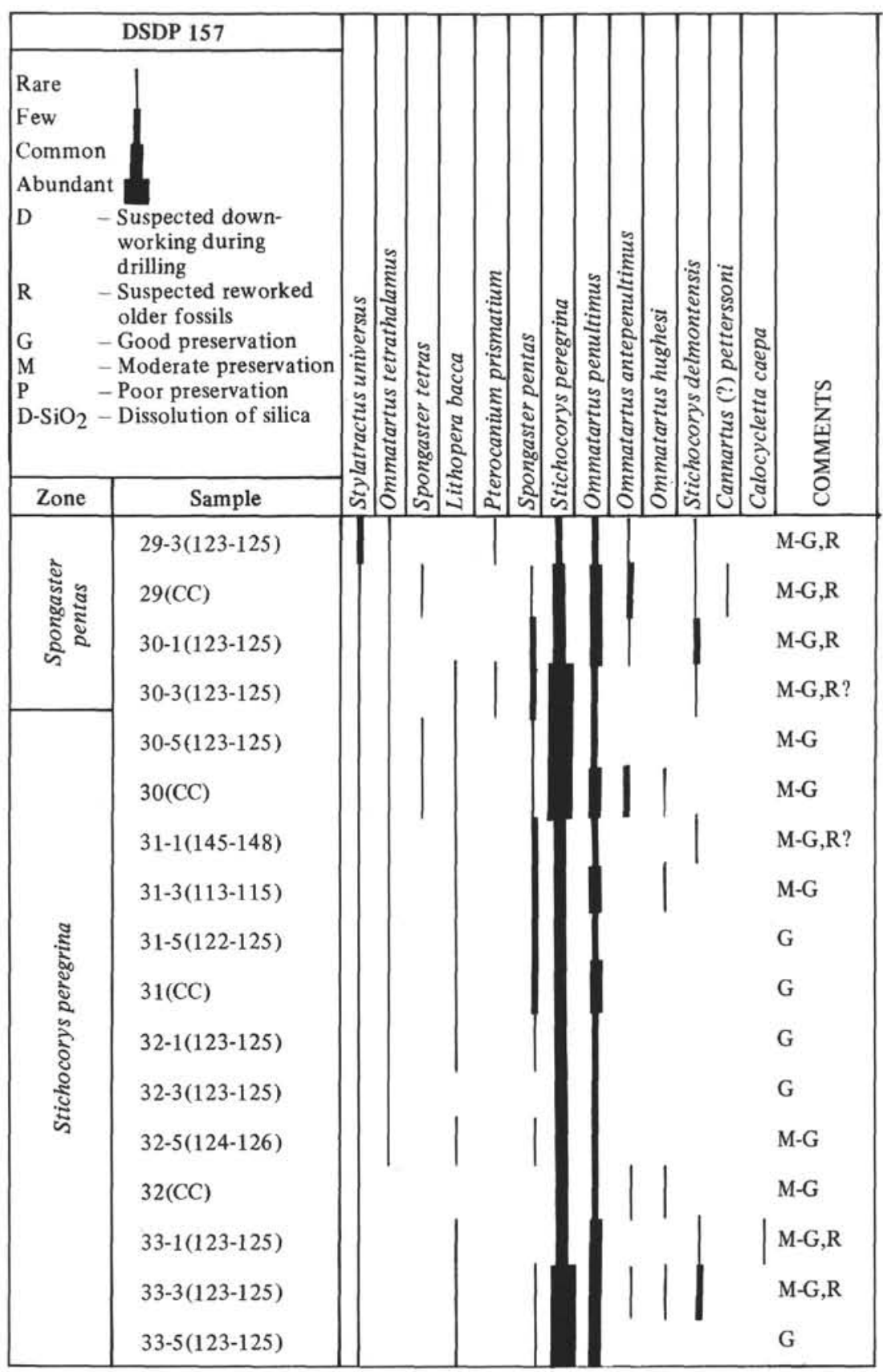

Figure 5. Continued.

There is no evidence of the presence of the Thyrsocyrtis tetracantha Zone. Thyrsocyrtis bromia is observed in the samples from the lower Upper Eocene before the first appearance of Thyrsocyrtis tetracantha. Consideration of all the data concerning this interval obtained on Leg 16 has led to the conclusion that the range of Thyrsocyrtis tetracantha falls within that of Thyrsocyrtis bromia. Therefore, the Thyrsocyrtis tetracantha Zone should be eliminated.

There is ample evidence of reworking through the Oligocene and Lower Miocene sections. The reworked assemblage is mainly of Middle Eocene age and may represent most of the radiolarian zones of that interval, as indicated by the presence of Podocyrtis ampla, Podocyrtis mitra, and Podocyrtis chalara. In the upper part of the section, a small number of reworked early Oligocene microfossils commonly form part of the total assemblage examined.

The Lower Oligocene interval, in particular Cores 5 and 6 of Hole 161A, contains a significant number of reworked, late Oligocene radiolarian taxa besides the admixed Eocene fauna. A nearly complete assemblage of the Theocyrtis annosa Zone is present in these cores. Considering that above as well as below this interval a very distinct fauna of the Theocyrtis tuberosa is present, it is suggested that this Upper Oligocene material is a result of downworking during drilling, rather than having to rely on more complicated explanations. 


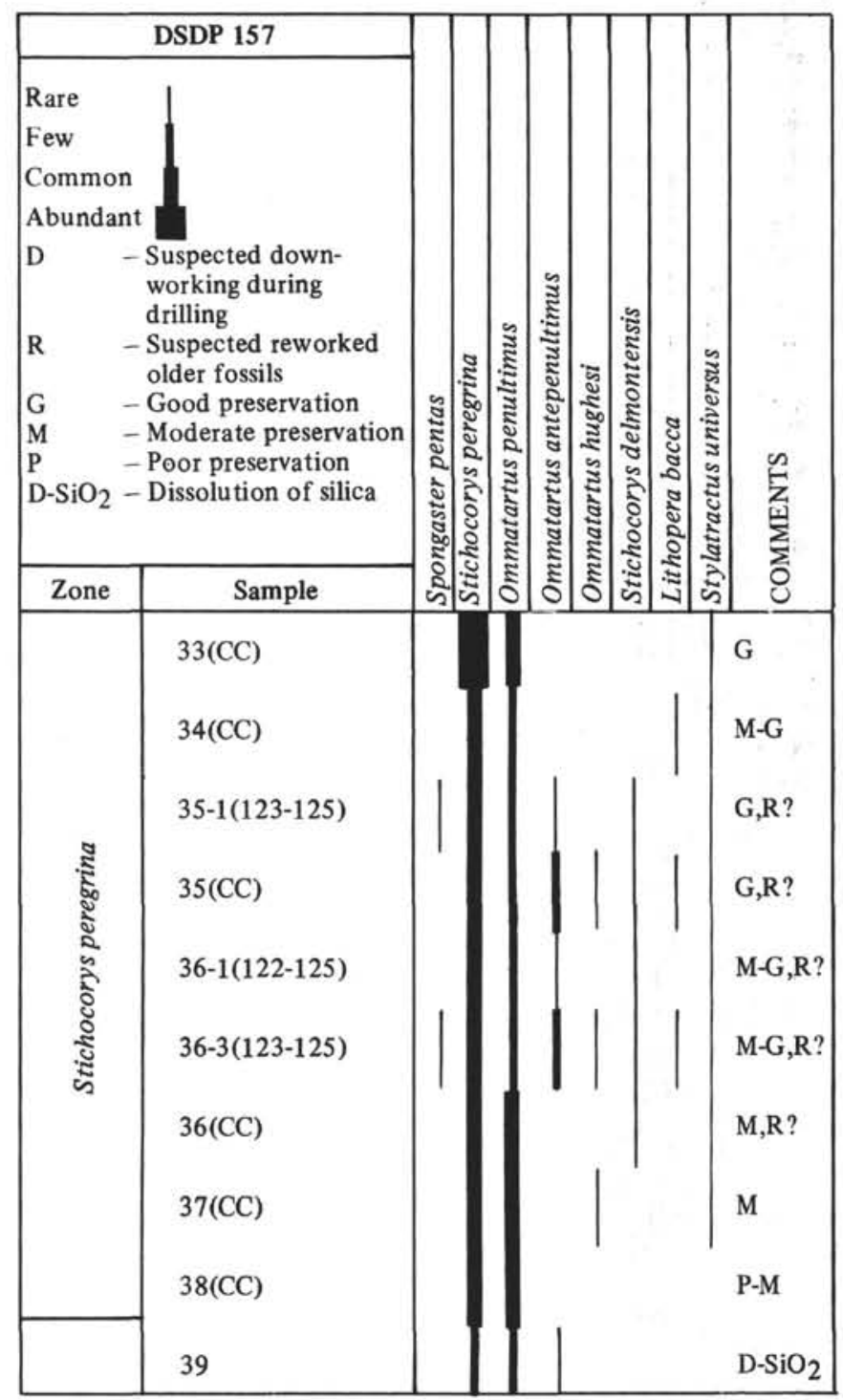

Figure 5. Continued.

\section{DSDP $162\left(14^{\circ} 52.2^{\prime} \mathrm{N}, 140^{\circ} 02.6^{\prime} \mathrm{W}\right)$ - Figure 10}

Late early Oligocene to early Middle Eocene Radiolaria are present in all seventeen cores from this site. Except for Cores 1, 2, and 17, the assemblages are rich, well preserved, and diversified. In the top 18 meters of sediment (Cores 1 and 2), Radiolaria are common and generally strongly to moderately corroded. Solution-resistant sponge spicules and orosphaerid spines and fragments are quite abundant throughout this interval. In a few samples of this section, rare specimens of late Oligocene species were observed, as well as rare, severely corroded specimens of Theocorythium trachelium trachelium (Cores 1-5) and of Spongaster tetras and Amphirhopalum ypsilon (Cores 2-5). This association suggests the presence of a thin Quaternary veneer at the top of the section, which has become admixed with older sediment during drilling. In Core 3 the number of sponge spicules and orosphaerid fragments rapidly declines; diatoms, which were rare in the top two cores, are quite common. The presence of Centrobotrys gravida and Dorcadospyris pseudopapilio in the catcher of Core 3 indicates this sample is from the lower Theocyrtis tuberosa Zone.

The sharp lithologic change from a nannofossil chalk ooze in Core 3 to a ferruginous clayey radiolarian ooze in Core 4 again marks the Oligocene-Eocene boundary. As at DSDP 161 Thyrsocyrtis bromia occurs in the top Eocene sample, and the same morphological change in Theocyrtis tuberosa was observed across this boundary, suggesting that there may be a possible hiatus in the record at this point.

In the Eocene section, from 26 to 153 meters (Cores 4-17), all radiolarian zones of Riedel and Sanfilippo (1970) were sampled with the exception of the Thyrsocyrtis tetracantha Zone, the absence of which has been discussed earlier.

In the lower half of Core 17, Section 1 a sudden increase in carbonate is associated with a sharp decline in the number of Radiolaria. Sections 2 and 3 of the same core are essentially barren of Radiolaria.

Although chert was encountered, in chips and pieces, in the catcher sample of Core 15, Radiolaria and diatoms are abundant and well preserved in samples from Core 15, Section 6 and Core 16, Section 1, indicating that no extensive vertical migration of silica from adjacent sediments was involved in the formation of the chert.

Reworking and mixing were most frequently encountered in the top 60 meters of the section. The admixed assemblage is usually of Middle Eocene age.

\section{DSDP $163\left(11^{\circ} 14.7^{\prime} \mathrm{N}, 150^{\circ} 17.5^{\prime} \mathrm{W}\right)$ - Figure 11}

A nearly complete lower Tertiary section was cored in the first 100 meters of sediment, a radiolarian ooze, and most of the radiolarian zones of the Paleogene of Moore (1971) were sampled at this site. Except for the top three cores, where preservation varies from poor to moderate, the assemblages are generally well preserved and of high diversity.

The first core yielded only two samples, from the top and the catcher. Both samples contain a few severely corroded specimens of Ommatartus tetrathalamus and Spongaster tetras, indicating a Quaternary to Pliocene age for this interval. A small fraction of the reworked fauna present in these samples is representative of the Dorcadospyris papilio Zone. However, the assemblage is dominated by a Middle Eocene fauna, and all biostratigraphic zones of that interval may be represented. A few specimens of the Upper Eocene Thyrsocyrtis bromia Zone are present as well.

The youngest Paleogene zone present is the Upper Oligocene Dorcadospyris papilio Zone in the upper half of Core 2 . Below this core a nearly continuous section to the Theocampe mongolfieri Zone (lowermost Middle Eocene) seems to be present.

Throughout the Theocyrtis annosa Zone the nominate species is unusually rare; however, most other species of this zonal assemblage occur quite frequently, although corrosion is evident. Either selective solution has affected the abundance of Theocyrtis annosa or its rarity may be ascribed to different ecological conditions existing at this site. As at DSDP Sites 70, 161, and 162, there is no evidence for the existence of the Thyrsocyrtis tetracantha Zone. 


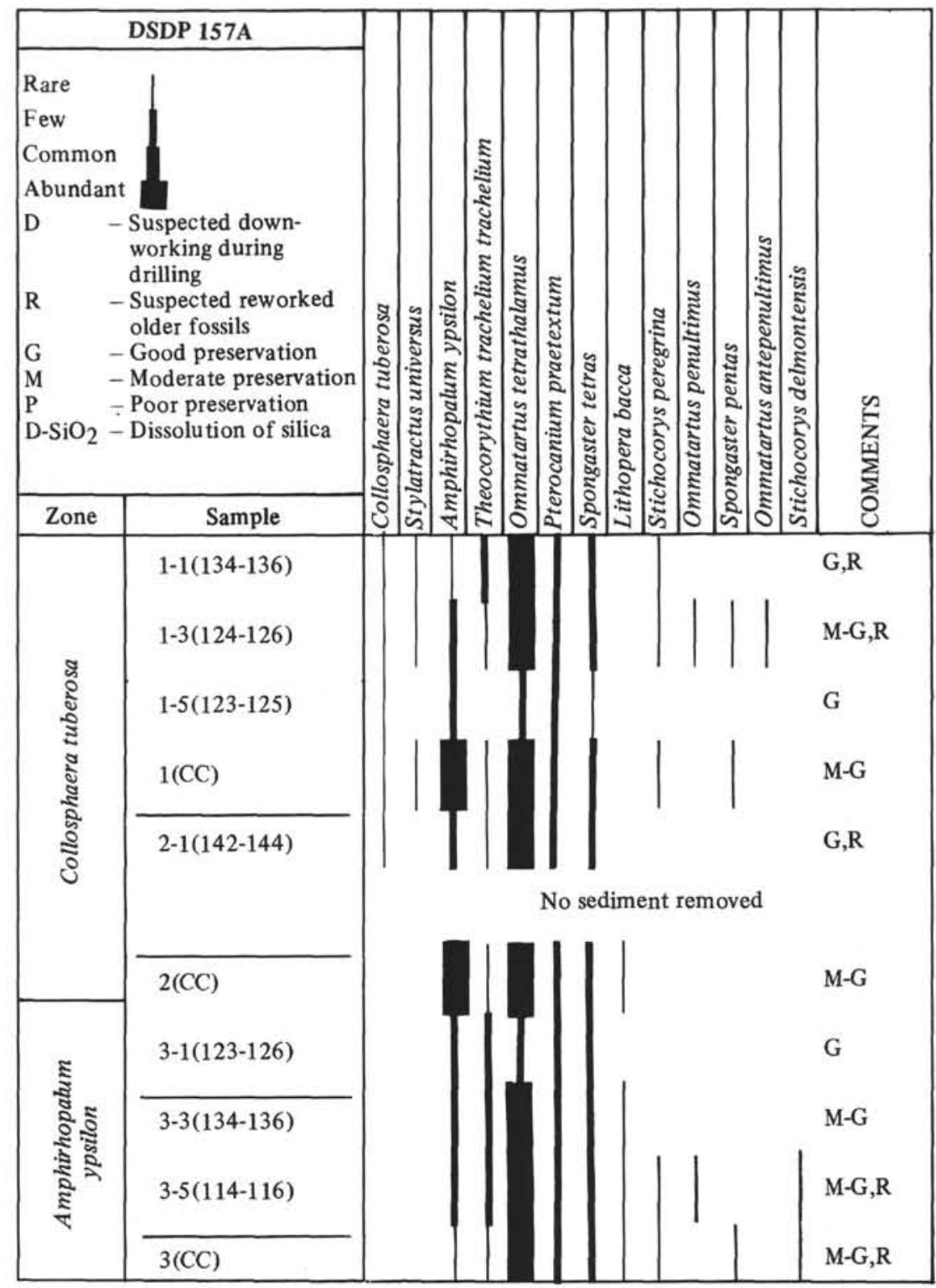

Figure 5. Concluded.

Due to the high porosity of the sediment, about 90 per cent, drilling disturbance is common in all cores from the Tertiary section. Particularly strong disturbance was observed in Cores 5, 7, and 9 to 12 . Thin beds of chert occur at several levels in the hole. Chips and pieces of these cherts. are found scattered throughout the cores and may have: contributed to the upward and downward contamination. In addition, extensive reworking, mainly of Middle Eocene taxa, is evident in the top six cores. For these reasons. several of the zone boundaries must be regarded with skepticism, notably the boundaries between the Thyrsocyrtis bromia and Podocyrtis goetheana zones in Core 6, and between the Podocyrtis mitra Zone and the Podocyrtis ampla Zone in Core 9. Podocyrtis goetheana is rather common in the lower part of Core 6. At this level it is already associatedl with specimens of Thyrsocyrtis bromia. The zonal boundary in Core 6, between Sections 3 and 5, is based mainly on the relative abundance of these two species in samples examined throughout the core. Similar reasoning is followed in Core 9 concerning the placement of the Podocyrtis ampla-Podocyrtis mitra zonal boundary.
Of course, the alternative solution is to extend the Thyrsocyrtis bromia Zone throughout Core 6 and the Podocyrtis mitra Zone throughout Core 9, and to assume the existence of two hiatuses in the section. However, there is some additional evidence for the Podocyrtis goetheana Zone. In Core 7, Section 1, the upper part of the Podocyrtis chalara Zone, a sphaeroid radiolarian, probably of the family Liosphaeridae, is common. The same species is also common in the catcher sample of Core 6. At DSDP 161 and 162 this species is abundant in samples from the uppermost Podocyrtis chalara Zone, while its abundance was observed to decline rapidly in numbers in the lower part of the Podocyrtis goetheana Zone. Thus, although the species does not occur in as great a number as at the previous two sites, it seems likely that the latter zone is present at this site.

Core 12 contains the oldest Tertiary sediment recovered at DSDP 163. The presence of Podocyrtis aphorma, Lithochytris archea, Lamptonium ? fabaeforme? fabaeforme, and Theocotyle cryptocephala? nigrinae in Section 


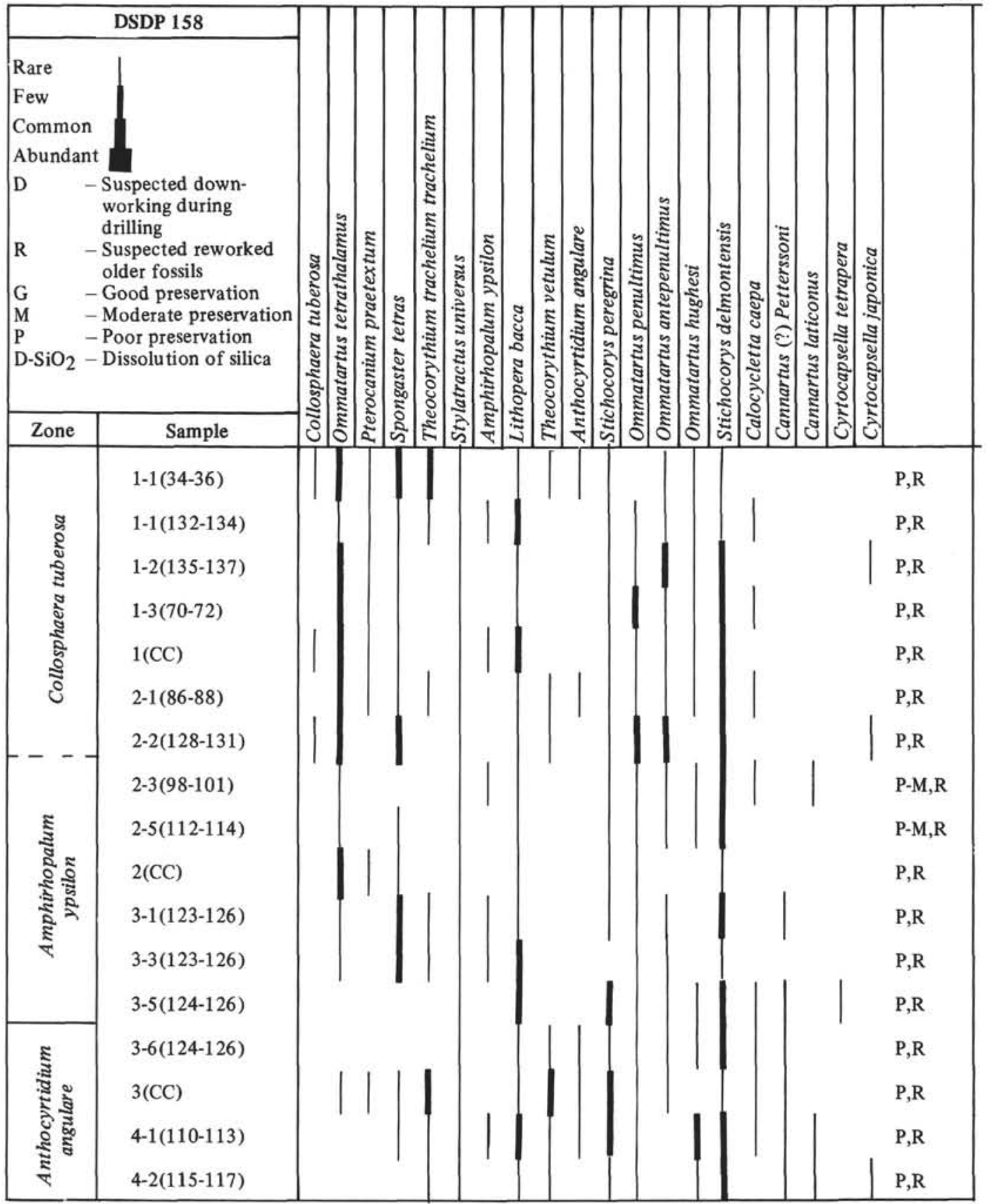

Figure 6. Radiolaria at DSDP 158.

3 of this core indicates the lowest part of the Theocampe mongolfieri Zone.

Fragments of meshwork and spines of orosphaerid Radiolaria are quite common in the Oligocene and uppermost Eocene interval. Sponge spicules occur throughout the section, but are most abundant in the top cores. Diatoms are common in Cores 4 and 10 and provide correlation to similar occurrences in the lower Oligocene and Middle Eocene of DSDP 162.

The sediment recovered in the lower cores (15-27) and that of DSDP 163A contains rare Radiolaria of late Cretaceous age. The preservation is very poor and identification to the species level is very difficult.

\section{SYSTEMATICS, CENOZOIC RADIOLARIA}

The radiolarian classification used in this report is based on the recent work of Riedel (1967a,b, 1971) who revised the earlier classification of
Haeckel. The taxonomy applied here relies heavily on recently completed investigations of Riedel and Sanfilippo (1970, 1971), Sanfilippo and Riedel (1970) and Moore (1971, and in press). These papers also contain more extensive synonomies for most of the species discussed in this report than are presented here.

\section{Order POLYCYSTINA Ehrenberg}

POLYCYSTINA Ehrenberg, 1838, emend. Riedel, 1967b, p. 291.

Suborder SPUMELLARIA Ehrenberg, 1875

Family COLLOSPHAERIDAE Muller, 1858

Genus COLLOSPHAERA Müller, 1855

Collosphaera tuberosa Haeckel, 1887 (Plate 10, Figures 1, 2)

Collosphaera huxleyi Müller, var. Haeckel, 1862, pl. 34, figs. 3, 9 Collosphaera tuberosa Haeckel, 1887, p. 97

Collosphaera tuberosa Haeckel, Nigrini, 1971, pl. 34. 1, fig. 1 


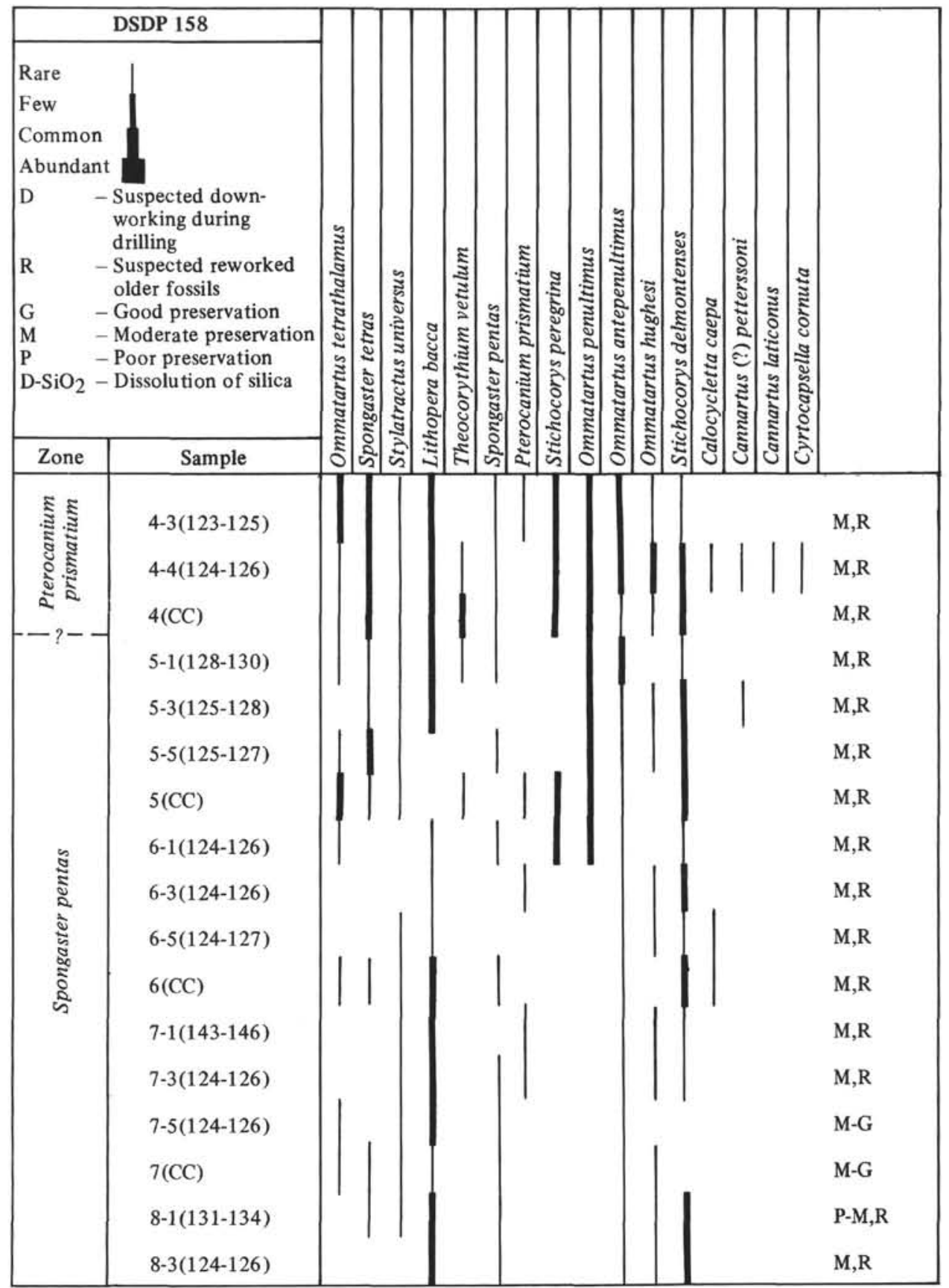

Figure 6. Continued.

\section{Genus TRIBONOSPHAERA Haeckel, 1881}

\section{Buccinosphaera invaginata Haeckel, 1887} (Plate 10, Figure 3)

Buccinosphaera invaginata Haeckel, 1887, p. 99, pl. 5, fig. 11 Buccinosphaera invaginata Haeckel, Nigrini, 1971, pl. 34, 1, fig. 2

Family ACTINOMMIDAE Haeckel

Actinommidae Haeckel, 1862, emend. Riedel, 1967b, p. 294.

\section{Genus LITHAPIUM Haeckel}

Lithapium Haeckel, 1887, p. 303 . Type species (designated by Campbell, 1954, p. 69) Lithapium pyriforme Haeckel (1887, p. 303, pl. 14, fig. 9).

Lithapium (?) plegmacantha Riedel and Sanfilippo

Lithapium (?) plegmacantha Riedel and Sanfilippo, 1970, pl. 4, figs. 2, 3.
Lithapium (?) plegmacantha Riedel and Sanfilippo, 1971, pl. 1, fig. 1.

\section{Lithapium (?) anoectum Riedel and Sanfilippo}

Lithapium (?) anoectum Riedel and Sanfilippo, 1970, pl. 4, figs. 4, 5.

Lithapium (?) mitra (Ehrenberg) (?)

(?) Cornutella mitra Ehrenberg, 1873, p. 221; 1875, pl. 2, fig. 8.

(?) Cornutella circularis Ehrenberg, 1873, p. 221; 1875, pl. 2, fig. 4.

Lithapium (?) mitra (Ehrenberg); Riedel and Sanfilippo, 1970, pl. 4, figs. 6, 7.

Lithapium (?) mitra (Ehrenberg), Moore, 1971, pl. 3, fig. 1.

Genus STYLATRACTUS Haeckel, 1887

Stylatractus Haeckel, 1887, p. 328. Type species (designated by Campbell, 1954, p. 73) Stylatractus neptunus Haeckel, 1887, p. 328, pl. 17, fig. 6). 


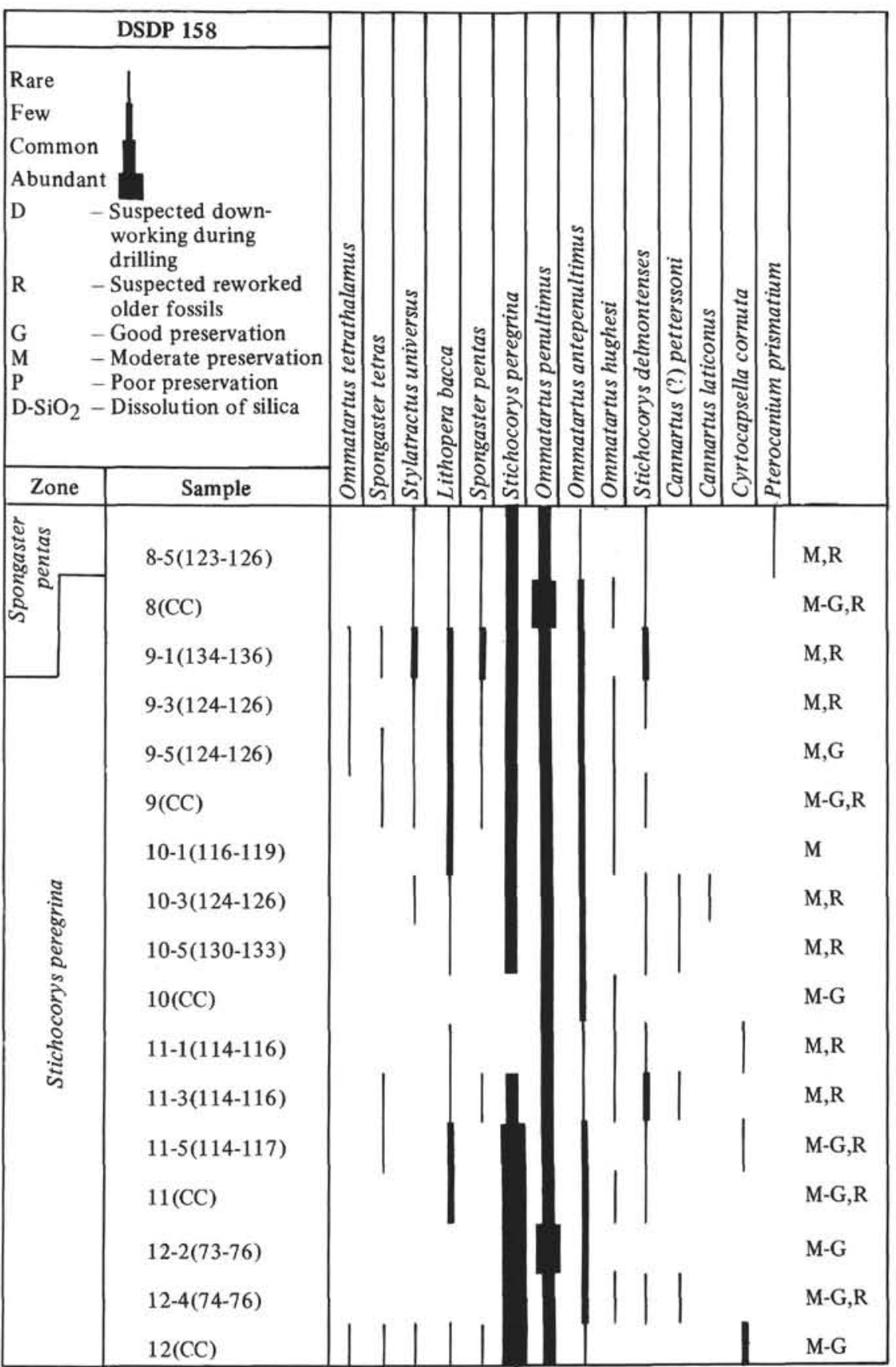

Figure 6. Continued.

\section{Stylatractus universus Hays \\ (Plate 10 Figures 6, 7)}

Stylatractus sp. Hays, 1965, p. 167, pl. 1, fig. 6.

Stylatractus universus Hays, 1970, pl. 1, figs. 1, 2.

\section{Genus CANNARTUS (Haeckel)}

Cannartus Haeckel, 1881, p. 462. Type species (indicated by Campbell, 1954, p. 74). Cannartus violina Haeckel (1887, p. 358, pl. 39, fig. 10). Cannartus Haeckel, emend. Riedel, 1971.

\section{Cannartus prismaticus (Haeckel)} (Plate 5, Figure 5)

Pipetella prismatica Haeckel, 1887, p. 305

Cannartus prismaticus (Haeckel); Riedel and Sanfilippo, 1970, pl. 15, fig. 1
Cannartus tubarius (Haeckel)

(Plate 5, Figures 3, 4)

Pipettaria tubaria Haeckel, 1887, p. 339, pl. 39, fig. 15; Riedel, 1959, p. 289 , pl. 1, fig. 2.

Cannartus tubarius (Haeckel); Riedel and Sanfilippo, 1970, pl. 15, fig. 2. Remarks: Plate 5, Figure 3 shows an early form of this species. The form illustrated in Figure 4 is a later one.

\section{Cannartus violina Haeckel} (Plate 8, Figure 1)

Cannartus violina Haeckel, 1887, p. 358, pl. 39, fig. 10; Riedel, 1959, p. 290, pl. 1, fig. 3.

\section{Cannartus mammiferus (Haeckel)}

(Plate 3, Figures 2, 3)

Cannartidium mammiferum Haeckel, 1887, p. 375, pl. 39, fig. 16. Cannartus mammiferus (Haeckel); Riedel, 1959, p. 291, pl. 1, fig. 4. 


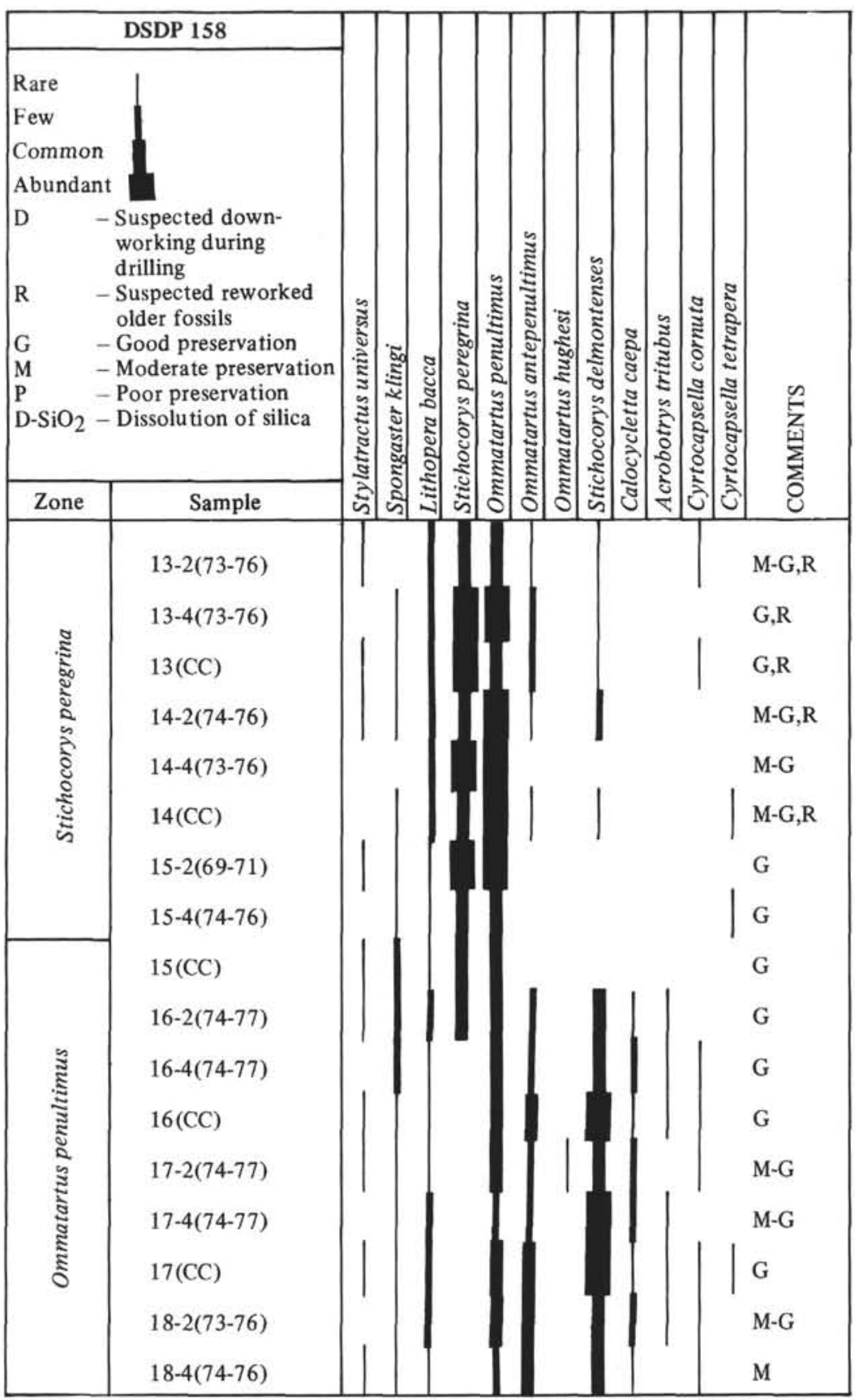

Figure 6. Continued.

\section{Cannartus laticonus Riedel}

(Plate 2, Figures 4, 8)

Cannartus laticonus Riedel, 1959, p. 291, pl. 1, fig. 5.

Remarks: The form of Figure 6, Plate 8, although still showing all the characteristics for this species, probably stands close to the transition of $C$. laticonus to $C$. (?) petterssoni, as is indicated by the slightly cylindrical shape of the cortical shell.

\section{Cannartus (?) petterssoni Riedel and Sanfilippo}

$$
\text { (Plate 8, Figures 5, 9-11) }
$$

Cannartus petterssoni conditional manuscript name proposed in Riedel and Funnell, 1964, p. 310; Riedel and Sanfilippo, 1970, pl. 14, fig. 3

Remarks: The forms pictured in Figures 5 and 9 of Plate 8 both are early representatives of this species. Those illustrated in Figures 10 and 11 show the characteristic equatorial bulge and are more diagnostic for this species. These latter forms occur higher in the zone.

\section{Genus OMMATARTUS Haeckel}

Ommatartus Haeckel, 1881, p. 463. Type species indicated by Campbell, 1954, p. 76. Ommatartus amphicanna Haeckel (1887, p. 396). Ommatartus Haeckel, emend. Riedel, 1971.

\section{Ommatartus antepenultimus Riedel and Sanfilippo}

(Plate 8, Figures 7, 8)

Panarium antepenultimum, conditional manuscript name proposed by Riedel and Funnell, 1964,p. 311.

Ommatartus antepenultimus, Riedel and Sanfilippo, 1970, pl. 14, fig. 4.

\section{Ommatartus hughesi (Campbell and Clark) \\ (Plate 8, Figure 12)}

Ommatocampe hughesi Campbell and Clark, 1944, p. 23, pl. 3, fig. 12. Ommatartus hughesi (Clark and Campbell); Riedel and Sanfilippo, 1970, p. 521. 


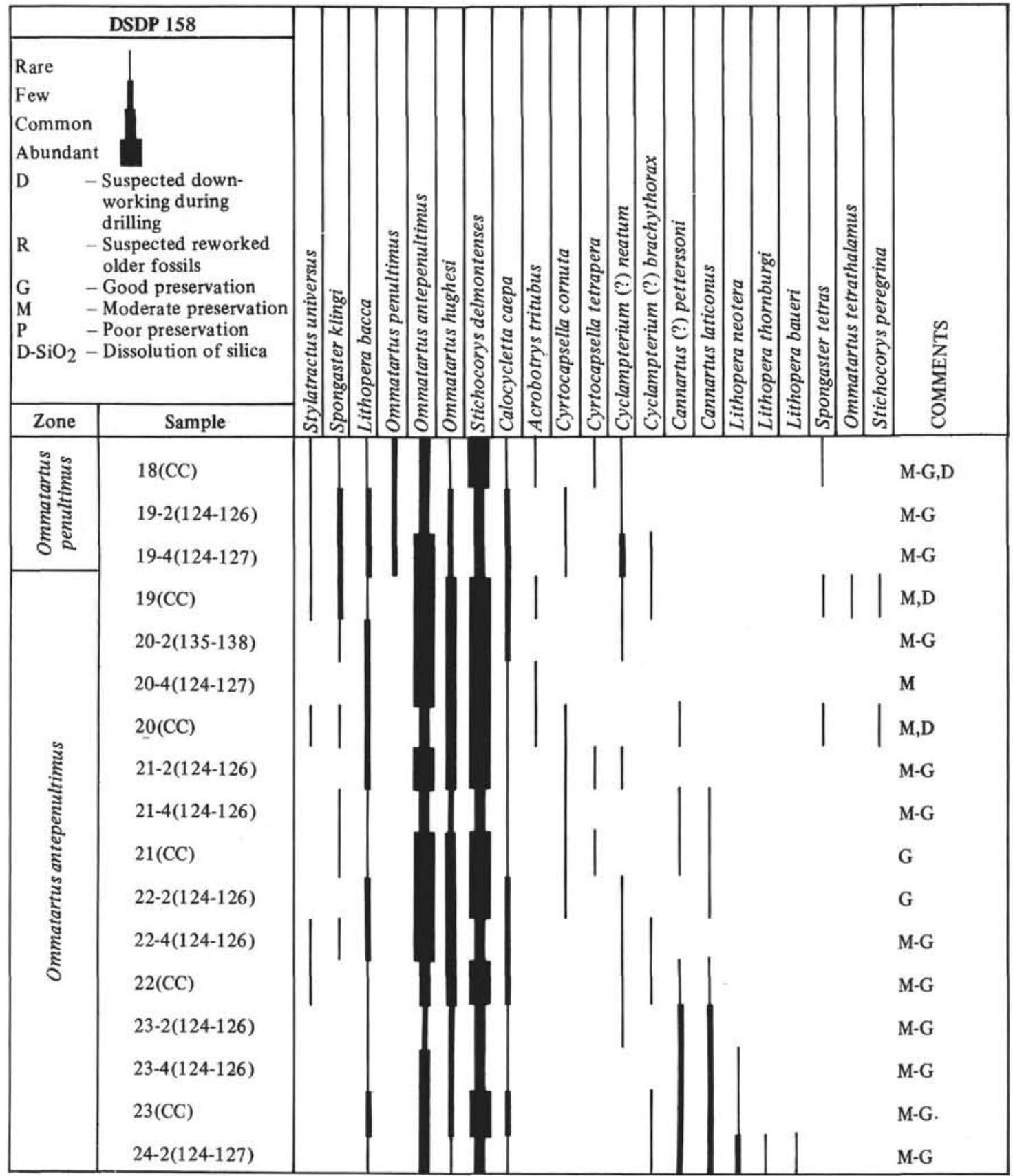

Figure 6. Continued.

\section{Ommatartus penultimus (Riedel) (Plate 9, Figures 7, 8)}

Panarium penultimum Riedel, 1957 , p. 76 , pl. 1, fig. 1

Ommatartus penultimus (Riedel); Riedel and Sanfilippo (sensu, stricto) 1970 , p. 521

Ommatartus tetrathalamus (Haeckel)

Panartus tetrathalamus Haeckel, 1887 , p. 378 , pl. 40 , fig. 3 ; Nigrini, 1967 , p. 30 , pl. 2 , figs. $4 a-4 d$.

\section{Family PHACODISCIDAE Haeckel, 1881}

\section{Genus TRIACTIS Haeckel}

Triactis Haeckel, 1881, p. 457; as used by Riedel and Sanfilippo, 1970, p. 521 .
Triactis tripyramis tripyramis Haeckel

Triactis tripyramis Haeckel, 1887, p. 432, pl. 33, fig. 6.

Triactis tripyramis tripyramis, Haeckel; Riedel and Sanfilippo, 1970, p. 521, pl. 4 , fig. 8.

Triactis tripyramis triangula (Sutton)

Phacotriactis triangula Sutton, 1896, p. 61.

Triactis trypyramis triangula (Sutton); Riedel and Sanfilippo, 1970, p. 521, pl. 4, figs. 9, 10.

\section{Family COCCODISCADAE Haeckel, 1862}

\section{Genus LITHOCYCLIA Ehrenberg}

Lithocyclia Ehrenberg 1847a, chart to p. 385. Type species (by monotype) Lithocyclia ocellus Ehrenberg (1854, p. 136. fig. 30; 1873, p. 240; 1875, pl. 29, fig. 3) and as used by Riedel and Sanfilippo, 1970, p. 522 . 


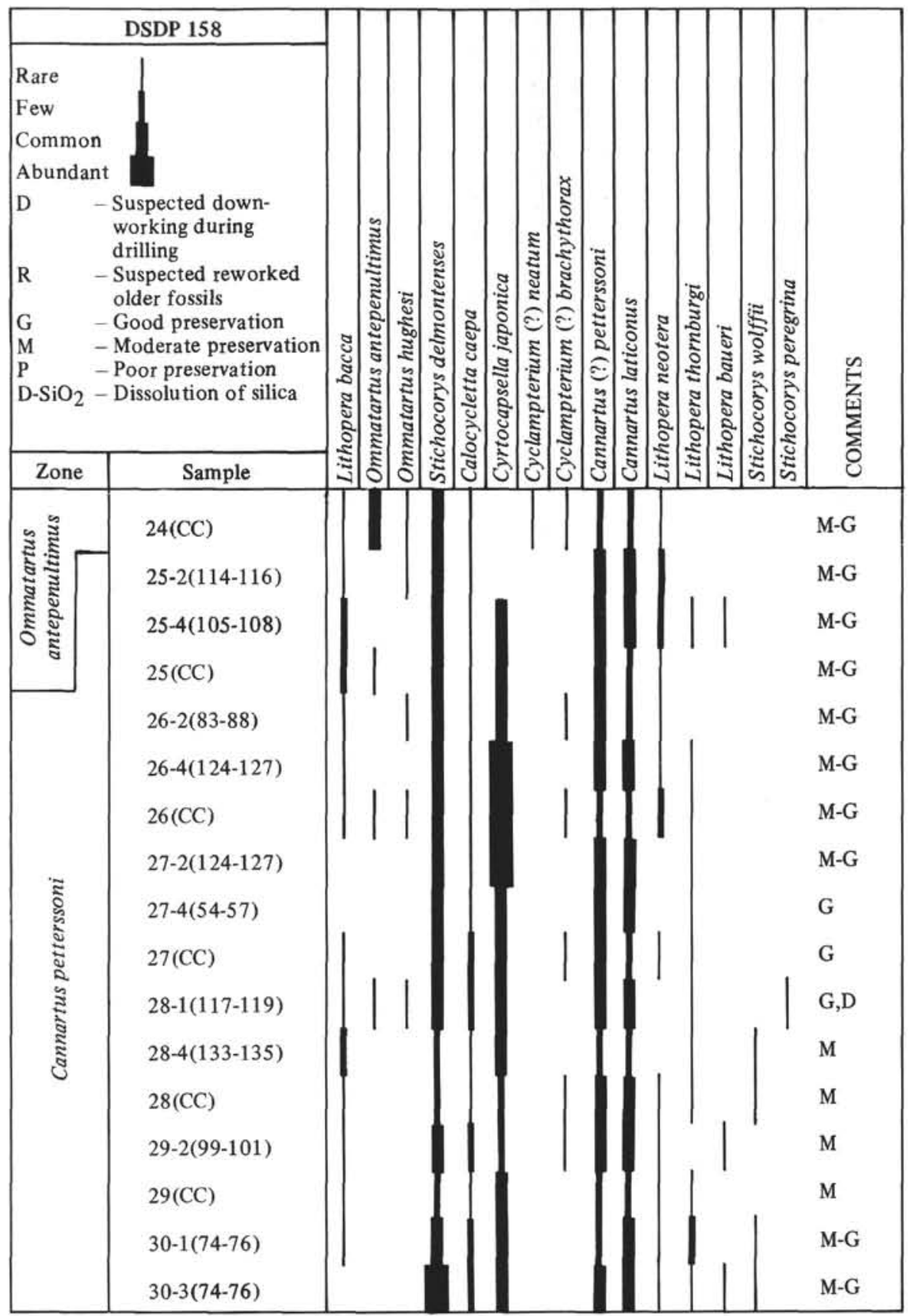

Figure 6. Continued.

\section{Lithocyclia crux Moore}

(Plate 6, Figure 9)

Lithocyclia crux Moore, 1971, p. 737, pl. 6, fig. 4.

\section{Lithocyclia angustum (Riedel)}

$$
\text { (Plate 5, Figures 7, 8) }
$$

Trigonactura angusta Riedel, 1959, p. 292, pl. 1, fig. 6.

Lithocyclia angustum (Riedel); Riedel and Sanfilippo, 1970, p. 13, figs. $1,2$.

Remarks: An early form of this species is shown in Figure 8 of Plate 5, whereas the one illustrated in Figure 7 is a later form.

\section{Lithocyclia ocellus group}

Lithocyclia ocellus group as used by Riedel and Sanfilippo, 1970, p. 522, pl. 5 , figs. 1,2 .

\section{Lithocyclia aristotelis group}

Lithocyclia aristotelis group as used by Riedel and Sanfilippo, 1970.

Family SPONGODISCIDAE Haeckel

Spongodiscidae Haeckel, 1862, emend. Riedel, 1967b, p. 295.

Genus AMPHIRHOPALUM Haeckel sens. emend.

Amphirhopalum Haeckel, 1881, p. 460. Type species Amphirhopalum ximorphum Haeckel (=A. maclaganium Haeckel). 1887 , p. 521 , pl. 45 , fig. 11 .

\section{Amphirhopalum ypsilon Haeckel}

(Plate 10, Figure 10)

Amphirhopalum ypsilon Haeckel, 1887, p. 522.

Amphirhopalum ypsilon Haeckel, Nigrini, 1967, p. 35, pl. 3, fig. 3a-d. Amphirhopalum ypsilon Haeckel, Nigrini, 1971, p. 447, pl. 34.1, fig. 7a-c. 


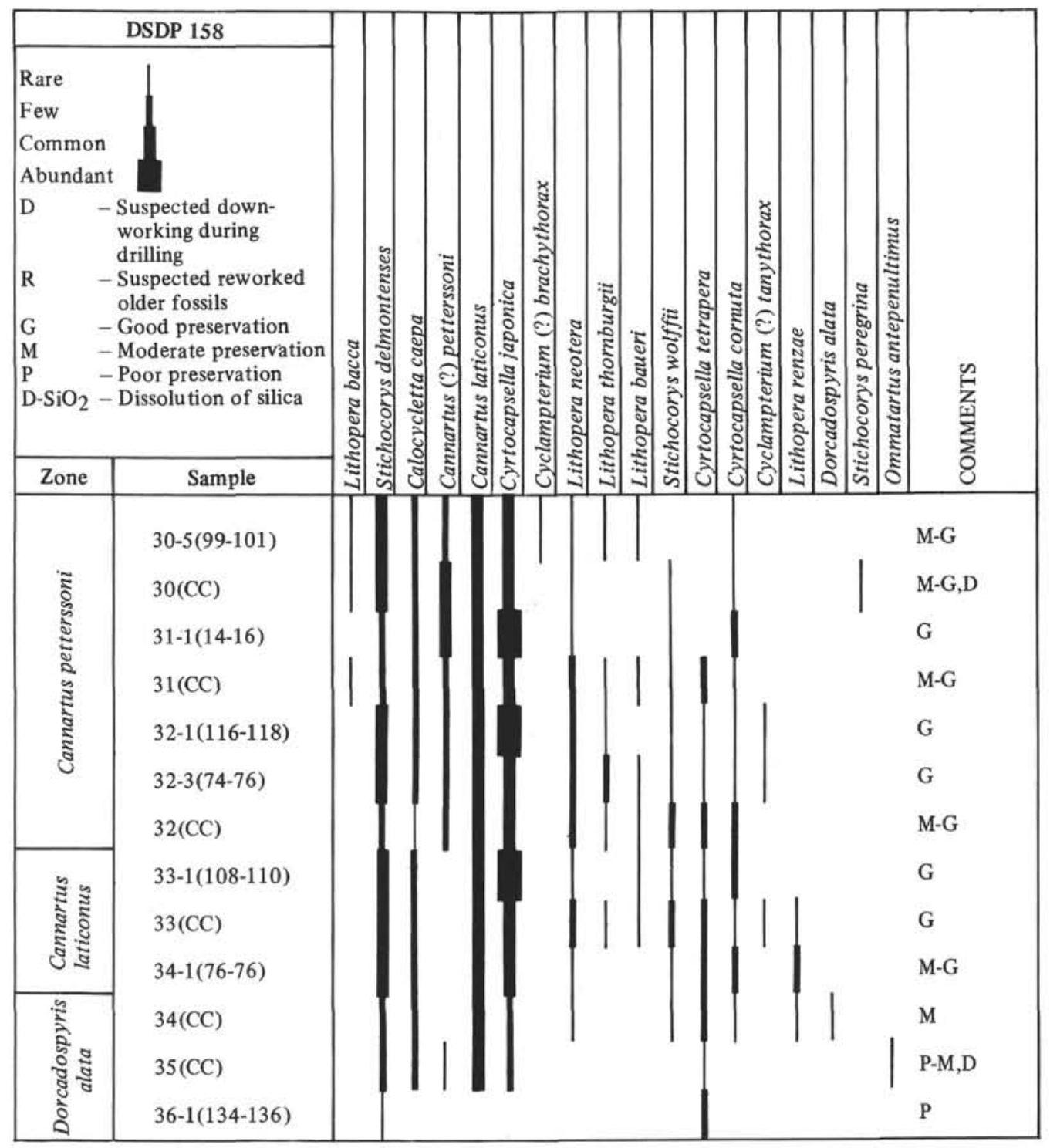

Figure 6. Concluded.

\section{Genus SPONGASTER Ehrenberg}

Spongaster Ehrenberg, 1860, p. 833. Type species (by monotype). Spongaster tetras Ehrenberg (1860; p. 833; 1861, p. 301; 1872b, pl. 6[3], fig. 8).

\section{Spongaster klingi Riedel and Sanfilippo}

"Elliptical spongodiscid," Kling, 1970, pl. 1, fig. J.

Spongaster klingi Riedel and Sanfilippo, 1971, pl. 1 D, figs. 8, 9, 10; plate 4, figs. 7,8 .

Spongaster pentas, Riedel and Sanfilippo (Plate 9, Figure 4)

Spongaster pentas Riedel and Sanfilippo, 1970, p. 523, pl. 15, fig. 3.

\section{Spongaster tetras Ehrenberg (Plate 10, Figure 4)}

Spongaster tetras Ehrenberg, 1860, p. 833.

\section{Suborder NASSALLARIA Ehrenberg, 1875}

Family ACANTHODESMIIDAE, Haeckel, 1862 Acanthodesmiidae Haeckel; Riedel, 1967b, p. 296.

\section{Genus DORCADOSPYRIS Haeckel}

Dorcadospyris Haeckel, 1881, p. 441. Type species (indicated by Campbell, 1954, p. 112)

Dorcadospyris dentata Haeckel (1887, p. 1040, pl. 85, fig. 6).

Dorcadospyris Haeckel; emend. Goll, 1969, p. 335.

\section{Dorcadospyris triceros (Ehrenberg)} (Plate 4, Figure 1)

Ceratospyris triceros Ehrenberg (1873, p. 220.; 1875, pl. 21, fig. 5)

Tristylospyris triceros (Ehrenberg); Haeckel, 1887, p. 1033. Riedel, 1959, p. 292 , pl. 1, figs. 7,8 .

\section{Dorcadospyris quadripes Moore} (Plate 4, Figures 4, 5)

Dorcadospyris quadripes Moore, 1971, pl. 7, figs. 3, 4, 5.

Dorcadospyris pseudopapilio Moore (Plate 4, Figures 2, 3)

Dorcadospyris pseudopapilio Moore, 1971, pl. 6, figs. 7, 8.

Dorcadospyris spinosa Moore

(Plate 4, Figures 8, 9)

Dorcadospyris spinosa Moore, 1971, pl. 7, figs. 1, 2. 


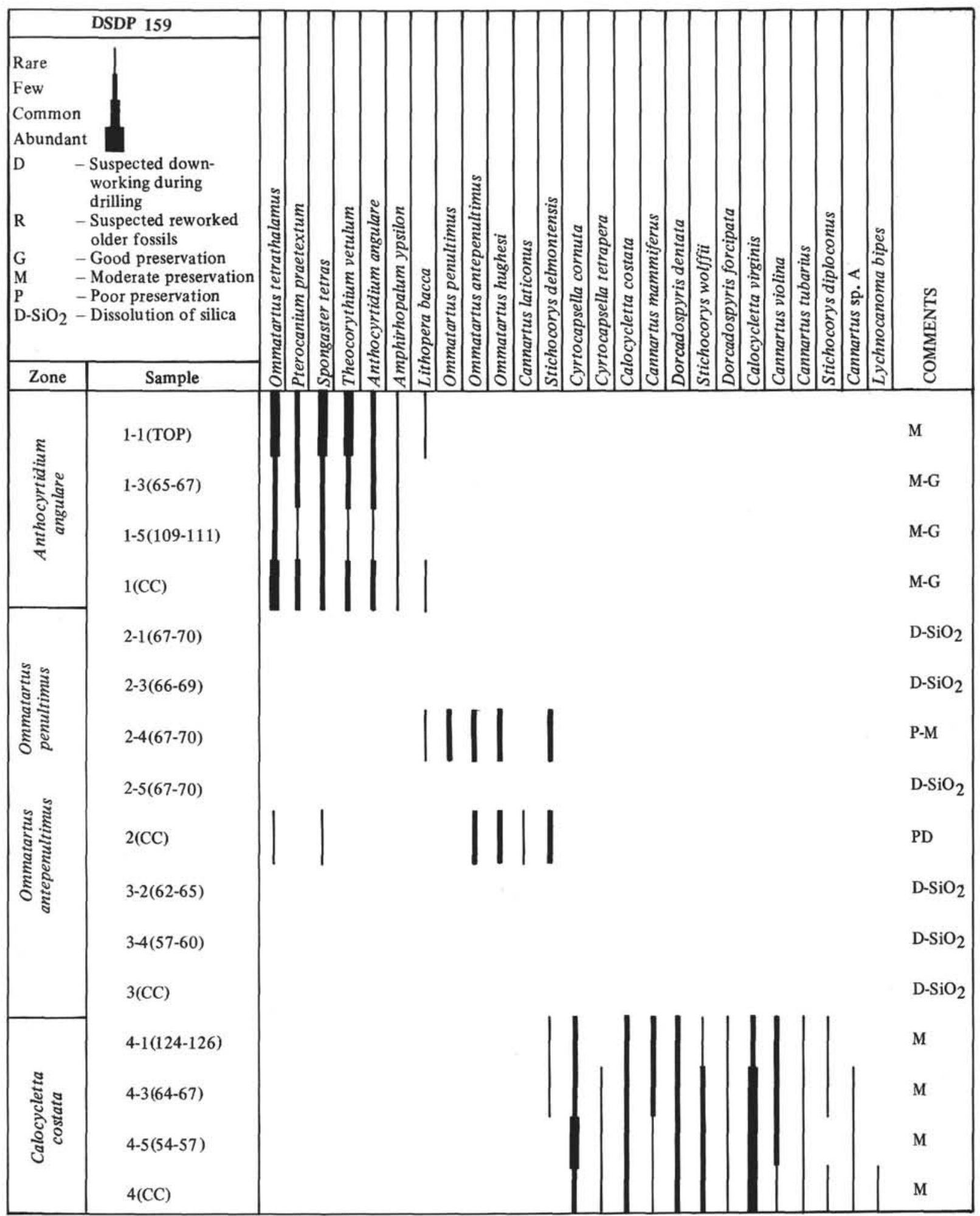

Figure 7. Radiolaria at DSDP 159.

Dorcadospyris ateuchus (Ehrenberg)

(Plate 6, Figure 5)

Ceratospyris ateuchus Ehrenberg, 1873, p. 218.

Cantharospyris ateuchus (Ehrenberg); Riedel, 1959, p. 294, pl. 22, figs. $3,4$.

Dorcadospyris ateuchus (Ehrenberg); Riedel and Sanfilippo, 1970, pl. 15, fig. 4 .

\section{Dorcadospyris circulus (Haeckel)}

(Plate 4, Figures 6, 7)

Gamospyris circulus Haeckel, 1887, p. 1042, pl. 83, fig. 19.

Remarks: In agreement with Moore (1971), Dorcadospyris circulus is used here in the broad sense and includes all specimens having two, semicircularly curved, primary feet which unite distally to form a ring. Two to six secondary feet, circular in section, are commonly found in 


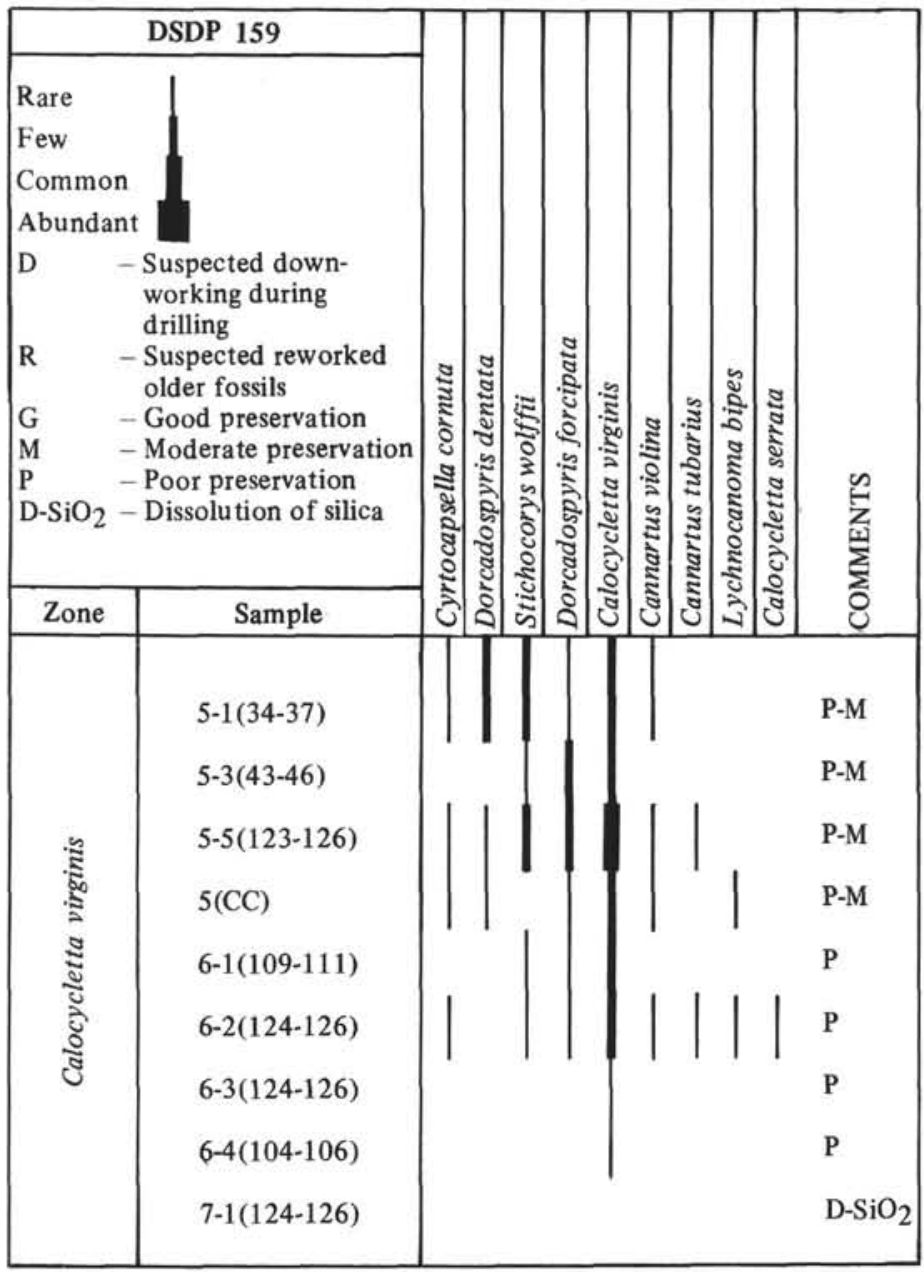

Figure 7. Continued.

well-preserved specimens. Toward the end of its range, forms are observed (Figure 6) which show the development toward D. riedeli in that some of its secondary feet arch up from the base of the shell and curve downward again distally.

\section{Dorcadospyris riedeli Moore}

(Plate 4, Figure 10)

Hexaspyris sp. Moore, 1968, pl. 3, figs. 3a, b. Dorcadospyris riedeli Moore, 1971, pl. 9, figs. 1, 2, 3 .

\section{Dorcadospyris papilio (Riedel) (Plate 6, Figure 6)}

Hexaspyris papilio Riedel, 1959, p. 294, pl. 2, figs. 1, 2.

Dorcadospyris papilio, (Riedel) Riedel and Sanfilippo, 1970, p. 15, fig. 5. Dorcadospyris papilio (Riedel), Moore, 1971, pl. 8, figs. 6, 7.

\section{Dorcadospyris praeforcipata Moore} (Plate 6 Figure 8)

Dorcadospyris forcipata (var) Haeckel, Moore, 1968, pl. 4, figs. 2a, 2b, 2c. Dorcadospyris praeforcipata (Moore), 1971, pl. 9, figures 4, 5, 6, 7 .

\section{Dorcadospyris simplex (Riedel)}

(Plate 6, Figures 2, 3, 4)

Brachiospyris simplex Riedel, 1959, p. 293, pl. 1, fig. 10.

Dorcadospyris simplex (Riedel); Riedel and Sanfilippo, 1970, pl. 15, fig. 6.

Dorcadospyris simplex (Riedel), Riedel and Sanifilippo, 1971, pl. 5, fig. 2.

Remarks: The three specimens illustrated in Figures 2, 3, and 4 of Plate 6 do not completely respond to the type description of Riedel, 1959. They all show a slight sagittal stricture and notably in Figures 3 and 4 the feet are not widely divergent proximally. Both latter forms occur already in the Lychnocanoma bipes Zone and may represent transitional stages from $D$. ateuchus to $D$. simplex. However, the form pictured in Figure 3 is similar to the one of Riedel and Sanfilippo, 1971, pl. 5, fig. 2, and thus it is assigned to D. simplex.

\section{Dorcadospyris forcipata (Haeckel) (Plate 6, Figure 7)}

Dipospyris forcipata Haeckel, 1887, p. 1037, pl. 85, fig. 1.

\section{Dorcadospyris dentata Haeckel}

Dorcadospyris dentata Haeckel, 1887, p. 1040, pl. 85, fig. 6; Riedel, 1957, p. 79 , pl. 1, fig. 4 .

Dorcadospyris alata (Riedel) (Plate 6, Figure 9)

Brachiospyris alata Riedel, 1959, p. 293, pl. 1., figs. 5, 11, 12.

Dorcadospyris alata (Riedel); Riedel and Sanfilippo, 1970, pl. 14, fig. 5.

\section{Family THEOPERIDAE Haeckel}

Theoperidae Haeckel, 1881, emend. Riedel, 1967b, p. 296.

\section{Genus ARTOPHORMIS Haeckel}

Artophormis Haeckel, 1881, p. 438. Type species (indicated by Campbell, 1954, p. 139). Artophormis horrida Haeckel (1887, p. 1458, pl. 75, fig. 2).

\section{Artophormis barbadensis (Ehrenberg)}

Calocyclas barbadensis Ehrenberg, 1873, p. 217; 1875, pl. 18, fig. 8 . Artophormis barbadensis (Ehrenberg) Riedel and Sanfilippo, 1970, p. 532 , pl. 13, fig. 5 . 


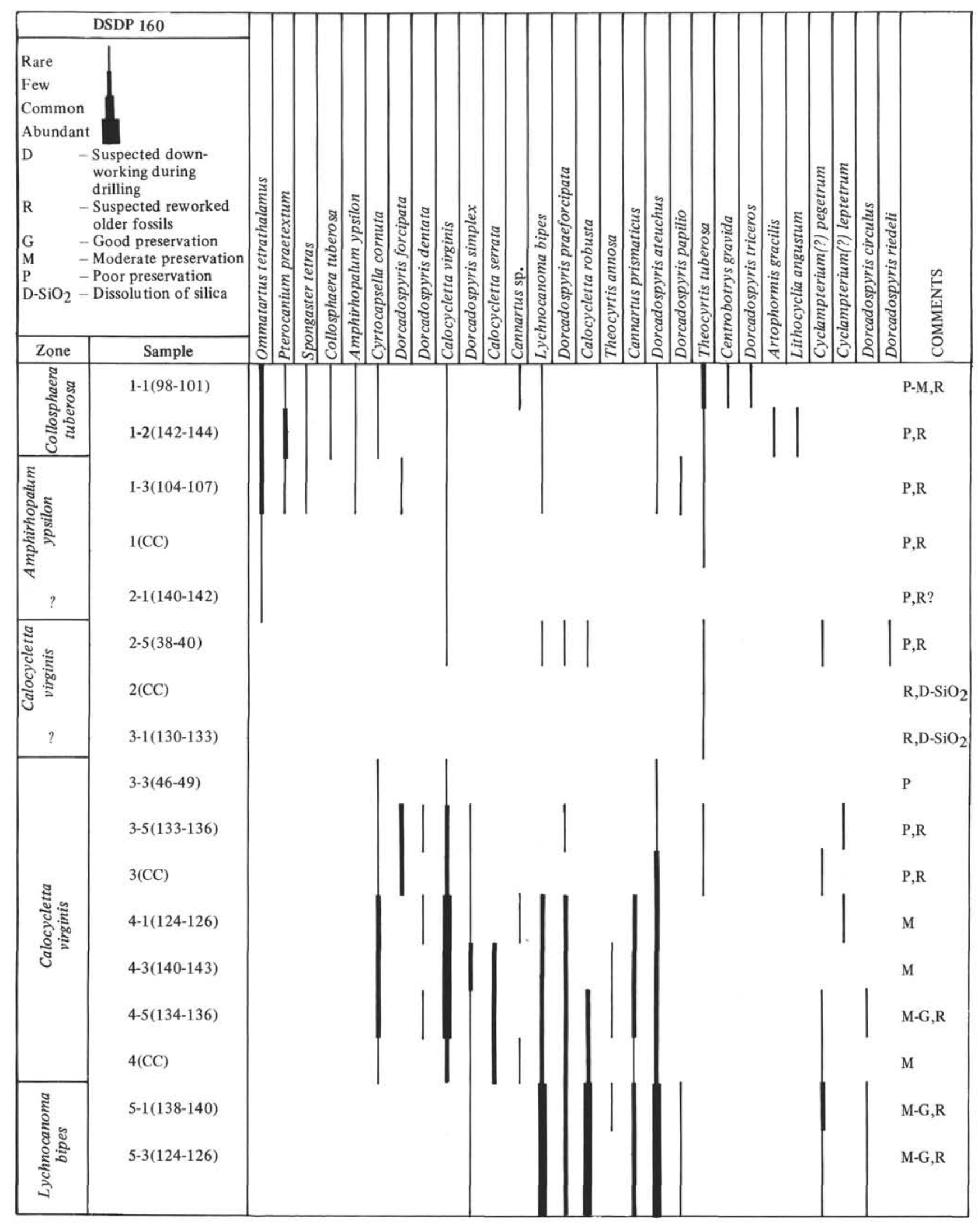

Figure 8. Radiolaria at DSDP 160. 


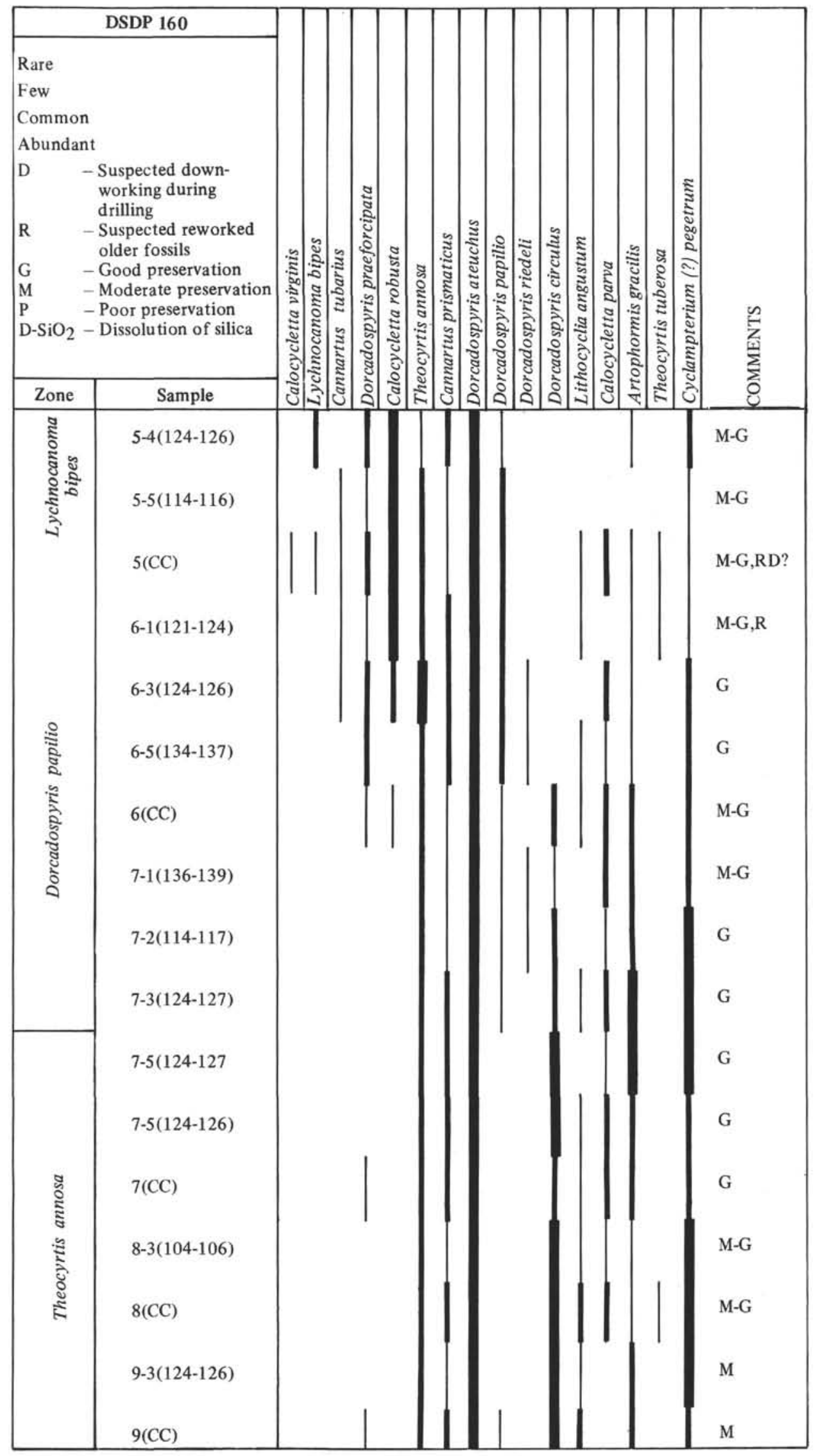

Figure 8. Continued. 


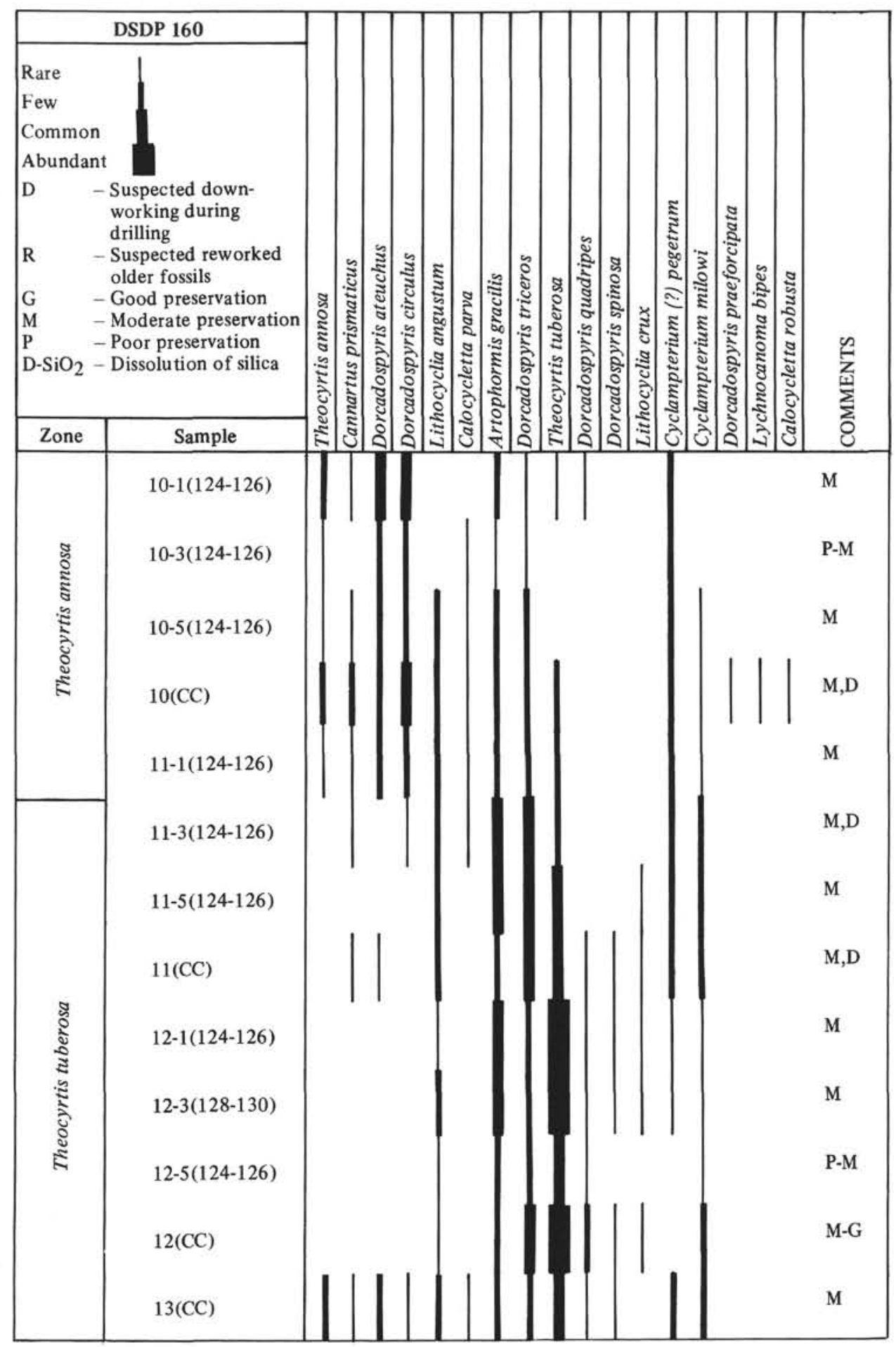

Figure 8. Continued.

\section{Artophormis gracilis Riedel}

Artophormis gracilis Riedel, 1959, p. 300, pl. 2, figs. 12, 13.

Genus CYCLADOPHORA Ehrenberg

Cycladophora Ehrenberg, 1847a, chart to p. 385 (indicated by Campbell, 1954, p. 132) Cycladophora stiligera Ehrenberg (1873, p. 223; 1875 pl. 18, fig. 3)

Calocyclas Ehrenberg, 1847b, chart to p. 54. Type species (indicated by Campbell, 1954, p. 132) Calocyclas turris Ehrenberg (1873, p. 218; 1875 , pl. 18 , fig. 7 ).

\section{Cycladophora hispida (Ehrenberg)}

Anthocyrtis hispida Ehrenberg, 1873, p. 216; 1875, pl. 8, fig. 2 Cycladophora hispida (Ehrenberg); Riedel and Sanfilippo, 1970, pl. 10, fig. 9.

Cycladophora turris Ehrenberg

Calocyclas turris Ehrenberg, 1873, p. 218; 1875, pl. 18, fig. 7.

Cycladophora stiligera Ehrenberg; 1873,

Cycladophora turris Ehrenberg; Riedel and Sanfilippo, 1970, p. 529, pl. 13 , figs. 3,4 . 


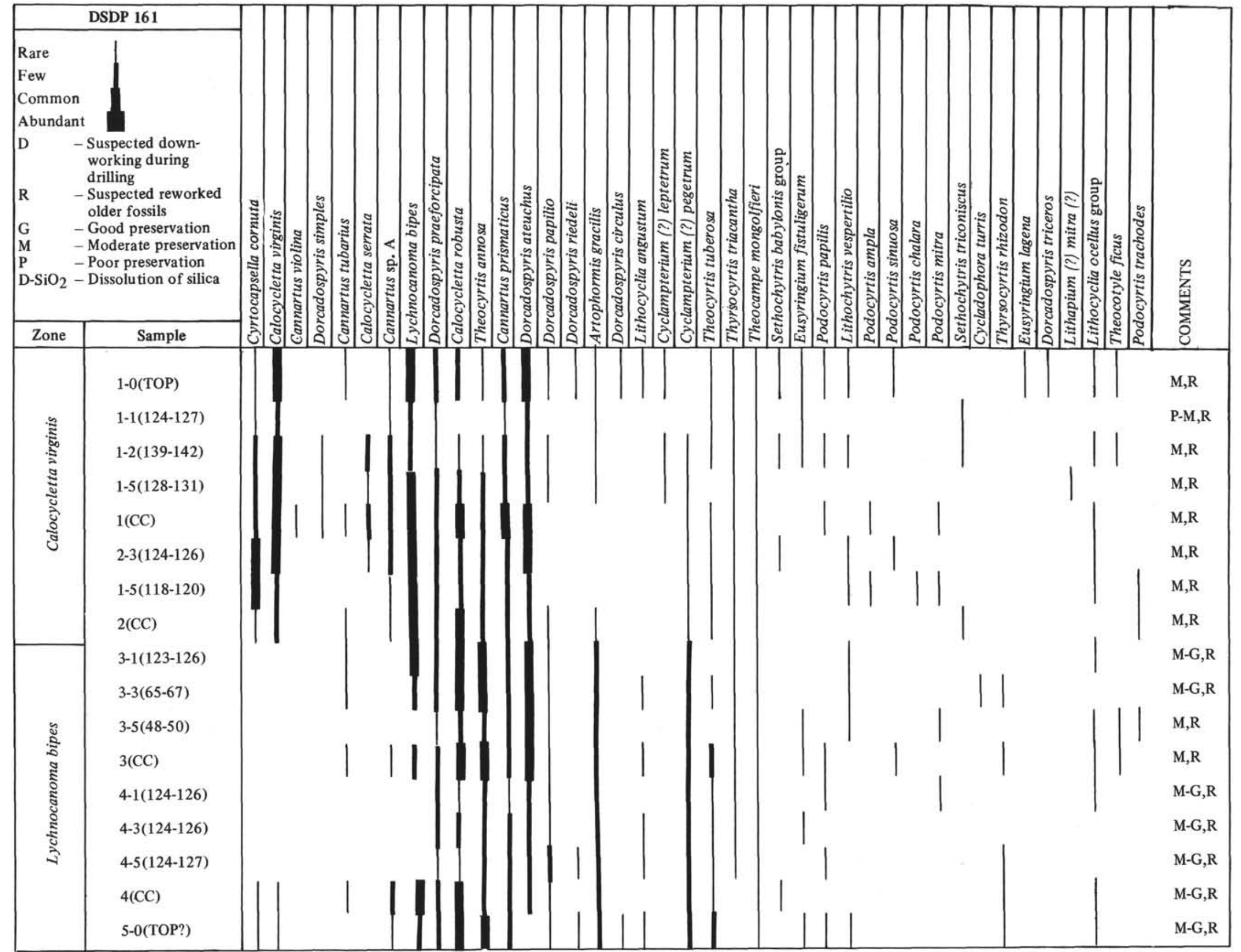




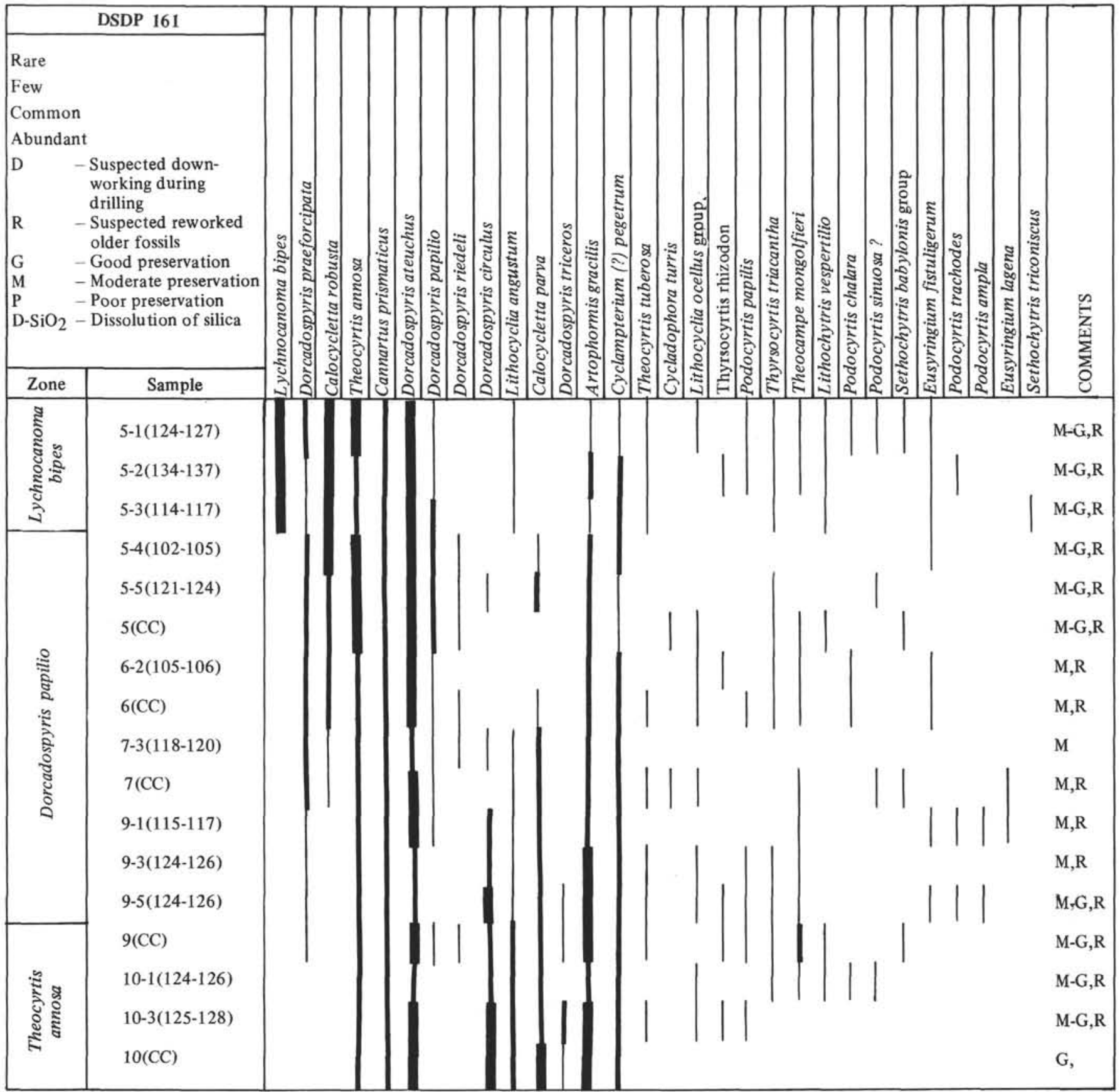

Figure 9. Continued.

\section{Genus CYCLAMPTERIUM Haeckel 1887}

(?) Cyclampterium Haeckel, 1887, p. 1379. Type species (designated by Campbell, 1954, p. 132) Cycladophora pantheon Haeckel, 1887, p. 1379, pl. 68, fig. 3 .

Cyclampterium (?) brachythorax Sanfilippo and Riedel

Cyclampterium (?) brachythorax Sanfilippo and Riedel, 1970, p. 457, pl. 2, figs. 15,16 .

\section{Cyclampterium (?) leptetrum Sanfilippo and Riedel}

Cyclampterium (?) leptetrum Sanfilippo and Riedel, 1970, p. 456, pl. 2 , figs. $11,12$.
Cyclampterium (?) milowi Riedel and Sanfilippo (Plate 2, Figure 1)

Cyclampterium (?) sp., Sanfilippo and Riedel, 1970, pl. 2, fig. 7 Cyclampterium (?) milowi Riedel and Sanfilippo, 1971, pl. 3B, fig. 3; pl. 7 , figs. 8,9 .

Cyclampterium (?) neatum Sanfilippo and Riedel

Cyclampterium (?) neatum Sanfilippo and Riedel, 1970, p. 457, pl. 2, figs. $17,18$.

Cyclampterium (?) pegetrum Sanfilippo and Riedel

Cyclampterium (?) pegetrum Sanfilippo and Riedel, 1970, p. 456, pl. 2, figs. 8,10 . 


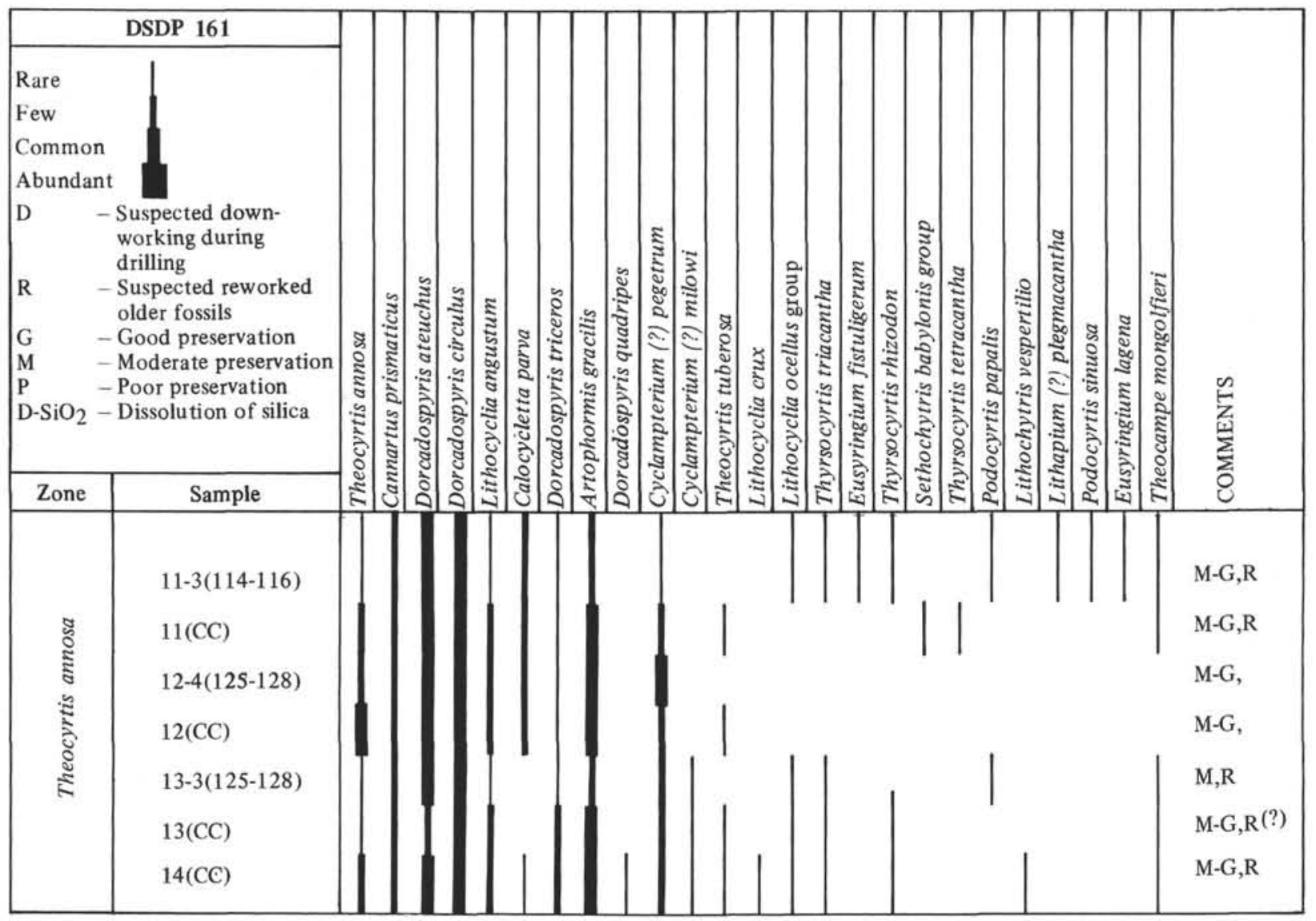

Figure 9. Continued.

\section{Cyclampterium (?) tanythorax Sanfilippo and Riedel}

Cyclampterium (?) tanythorax Sanfilippo and Riedel, 1970, p. 457, pl. 2, figs. $13,14$.

\section{Genus CYRTOCAPSELLA Haeckel}

Cyrtocapsella Haeckel, 1887, p. 1512. Type species (designated by Campbell, 1954, p. 143) Cyrtocapsa tetrapera Haeckel (1887, p. 1512, pl. 78, fig. 5). Genus as used by Riedel and Sanfilippo, 1970, p. 530.

Cyrtocapsella cornuta Haeckel

Cyrtocapsa cornuta Haeckel, 1887, p. 1513, pl. 78, tig. 9.

Cyrtocapsella cornuta Riedel and Sanfilippo, 1970, p. 531, pl. 14 fig. 8 .

\section{Cyrtocapsella japonica (Nakaseko)}

(Plate 9, Figure 5)

Eusyringium japonicum Nakaseko, 1963, p. 193, pl. 4, figs. 1-3. Cyrtocapsella japonica (Nakaseko), Sanfilippo and Riedel, 1970, p. 452 , pl. 1, figs. 13-15.

\section{Cyrtocapsella tetrapera Haeckel}

Cyrtocapsa tetrapera Haeckel, 1887, p. 1512, pl. 78, fig. 5 .

Cyrtocapsella tetrapera, Riedel and Sanfilippo, 1970, p. 531, pl. 14, fig. 7.

\section{Genus EUSYRINGIUM Haeckel}

Eusyringium Haeckel (1881, p. 437). Type species (designated by Frezzell and Middour, 1951, p. 35) Eusyringium conosiphon Haeckel (1887, p. 1496, pl. 78 , fig. 10).

Eusyringium fistuligerum (Ehrenberg)

[?] Eucyrtidium tubulus Ehrenberg, 1854, pl. 36, fig. 19; 1873, p. 233; 1875 , pl. 9 , fig. 6 .

Eucyrtidium fistuligerum Ehrenberg, 1873, p. 229; 1875, pl. 9, fig. 3.
Eusyringium fistuligerum (Ehrenberg) Haeckel, 1887, p. 1497; Riedel and Sanfilippo, 1970, p. 527, pl. 8, figs. 8, 9.

Eusyringium lagena (Ehrenberg) (?)

[?] Lithopera lagena Ehrenberg, 1873, p. 241; 1875, pl. 3, fig. 4. Eusyringium lagena (Ehrenberg) (?); Riedel and Sanfilippo, 1970, p. 527.

\section{Genus LAMPTONIUM Haeckel}

Lamptonium Haeckel, 1887, p. 1378, Type species (designated by Campbell, 1954, p. 132) Cycladophora enneapleura Haeckel (1887, p. 1378).

\section{Lamptonium (?) fabaeforme fabaeforme} (Krasheninnikov) (?)

[?] Cyrtocalpis fabaeformis Krasheninnikov, 1960, p. 296, pl. 3, fig. 11. Lamptonium (?) fabaeforme fabaeforme (Krasheninnikov)(?); Riedel and Sanfilippo, 1970, pl. 5, fig. 6 .

Lamptonium (?) fabaeforme (?) constrictum Riedel and Sanfilippo

Lamptonium (?) fabaeforme (?) constrictum Riedel and Sanfilippo, 1970, pl. 5 , fig. 7.

Lamptonium (?) fabaeforme (?) chaunothorax Riedel and Sanfilippo

Lamptonium (?) fabaeforme (?) chaunothorax Riedel and Sanfilippo, 1970, pl. 5, figs. $8,9$.

\section{Genus LITHOCHYTRIS Ehrenberg}

Lithochytris Ehrenberg, 1847a chart to p. 385. Type species (indicated by Campbell, 1954, p. 132) Lithochytris vespertilio Ehrenberg (1873, p. $239 ; 1875$, pl. 4 , fig. 10).

Lithochytris archea Riedel and Sanfilippo

Lithochytris archea Riedel and Sanfilippo; 1970, p. 528, pl. 9, fig. 7. 


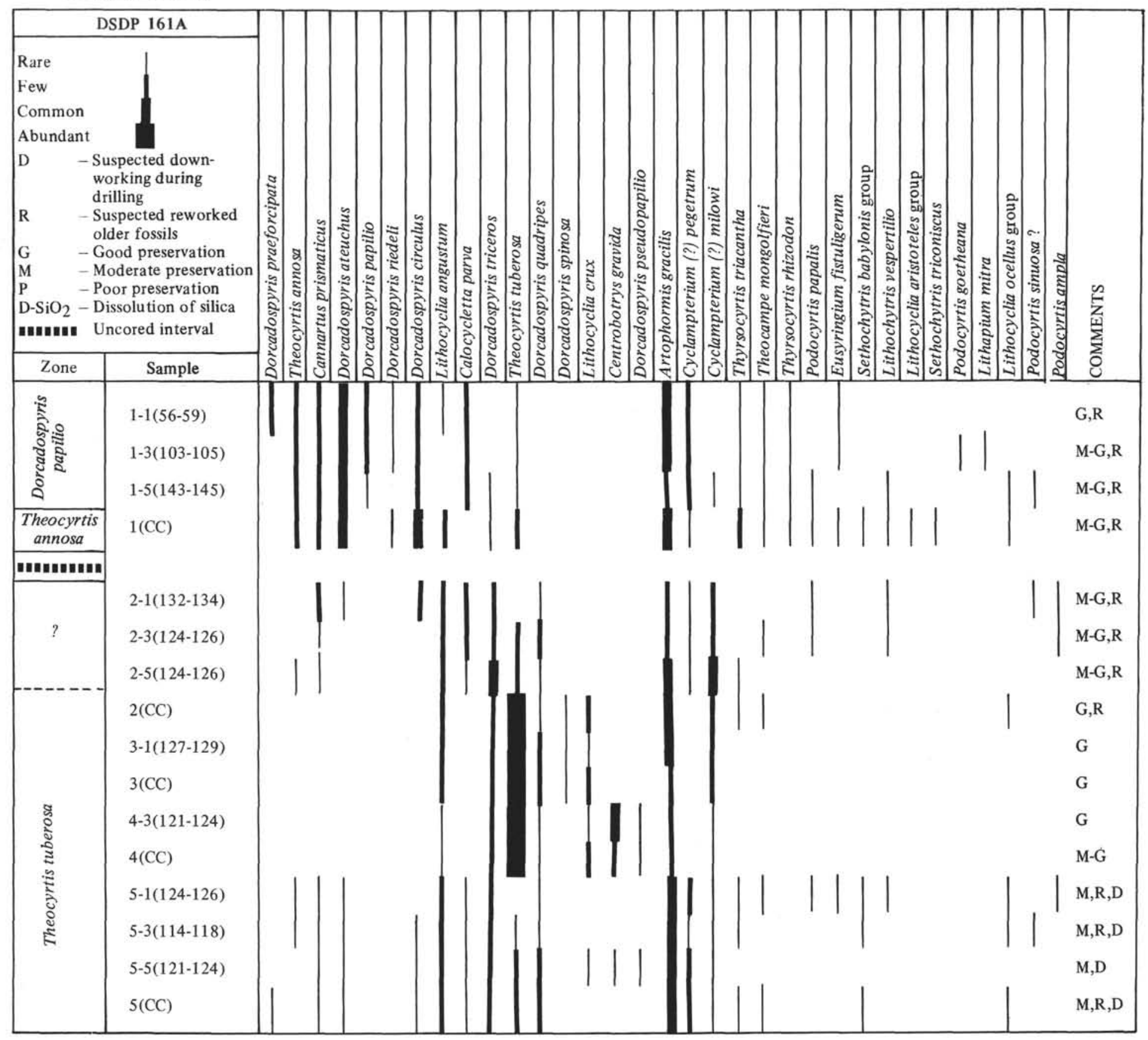

Figure 9. Continued.

Lithochytris vespertilio Ehrenberg

Lithochytris vespertilio Ehrenberg, 1873, p. 239; 1875, pl. 4, fig. 10;

Lithochytris cheopsis Clark and Campbell, 1942, p. 81, pl. 9, fig. 37.

Lithochytris vespertilio Ehrenberg; Riedel and Sanfilippo, 1970, pl. 9, figs.

$8,9$.

Genus LITHOPERA Ehrenberg 1847a

Lithopera Ehrenberg (1847a, chart to p. 385). Type species (indicated by Campbell, 1954, p. 124) Lithopera bacca Ehrenberg (1872a, p. 314; 1872 b, pl. 8 , fig. 1.)

\section{Lithopera (Lithopera) bacca Ehrenberg (Plate 9, Figure 6)}

Lithopera bacca Ehrenberg, 1872a, p. 314; 1872b, pl. 8, fig. 1; Nigrini, 1967 , p. 54, pl. 6, fig. 2; Sanfilippo and Riedel, 1970, p. 455, pl. 1, fig. 29.
Lithopera (Glomaria) baueri Sanfilippo and Riedel (Plate 9, Figure 13)

Lithopera baueri Sanfilippo and Riedel, 1970, p. 455, pl. 2, figs. 1-2.

Lithopera (Lithopera) neotera Sanfilippo and Riedel

(Plate 9, Figures 9, 10)

Lithopera neotera Sanfilippo and Riedel, 1970, p. 454, pl. 1, figs. 24-26, 28.

Lithopera (Lithopera) renzae Sanfilippo and Riedel

(Plate 9, Figures 11, 12)

Lithopera renzae Sanfilippo and Riedel, 1970, p. 454, pl. 1, figs. 21-23, 27.

Lithopera (Glomaria) thornburgi Sanfilippo and Riedel (Plate 9, Figure 14)

Lithopera thornburgi Sanfilippo and Riedel, 1970, p. 455, pl. 2, figs. 4-6. 


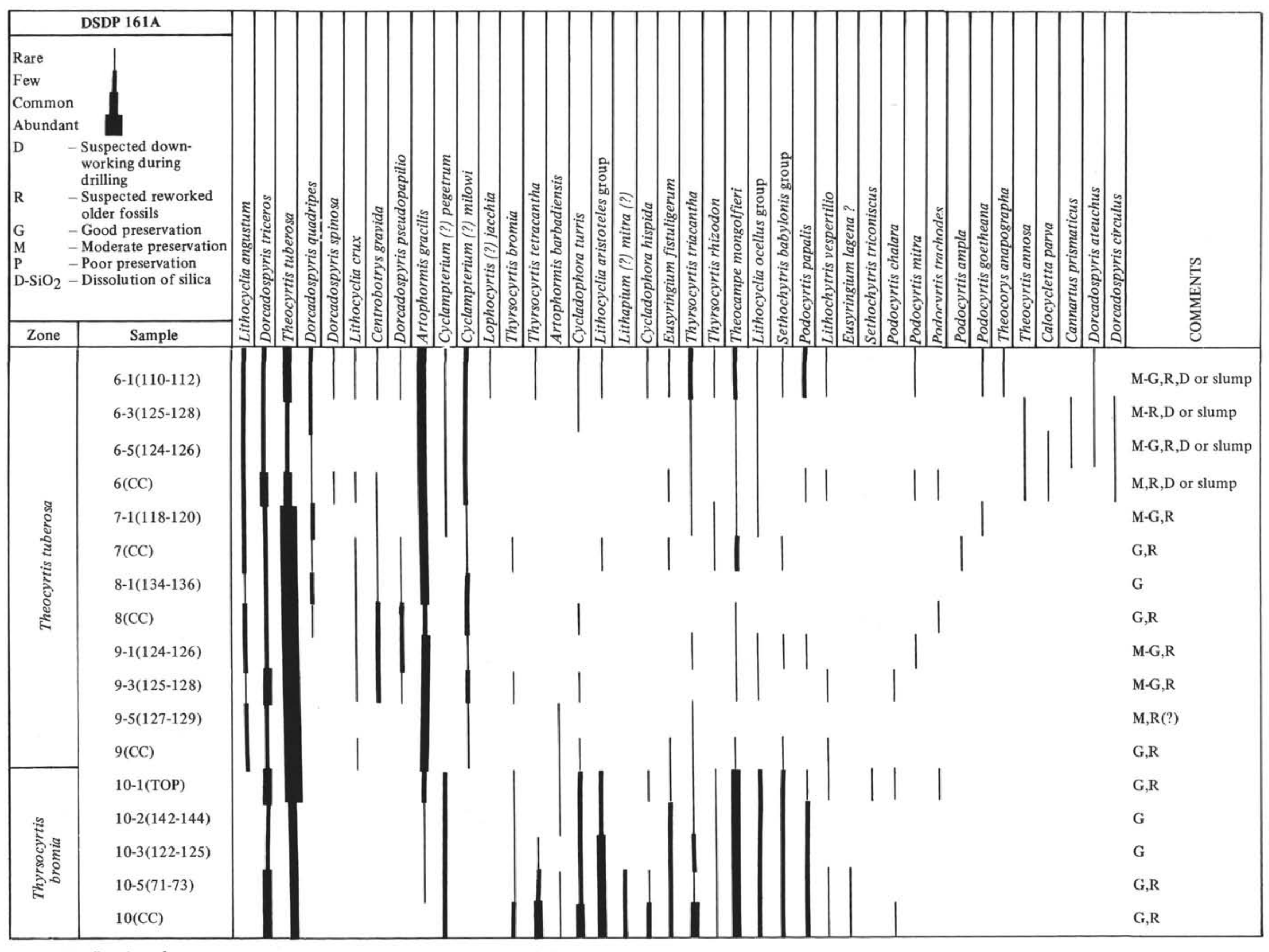

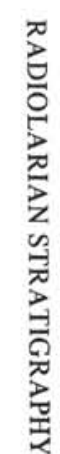

Figure 9. Continued. 


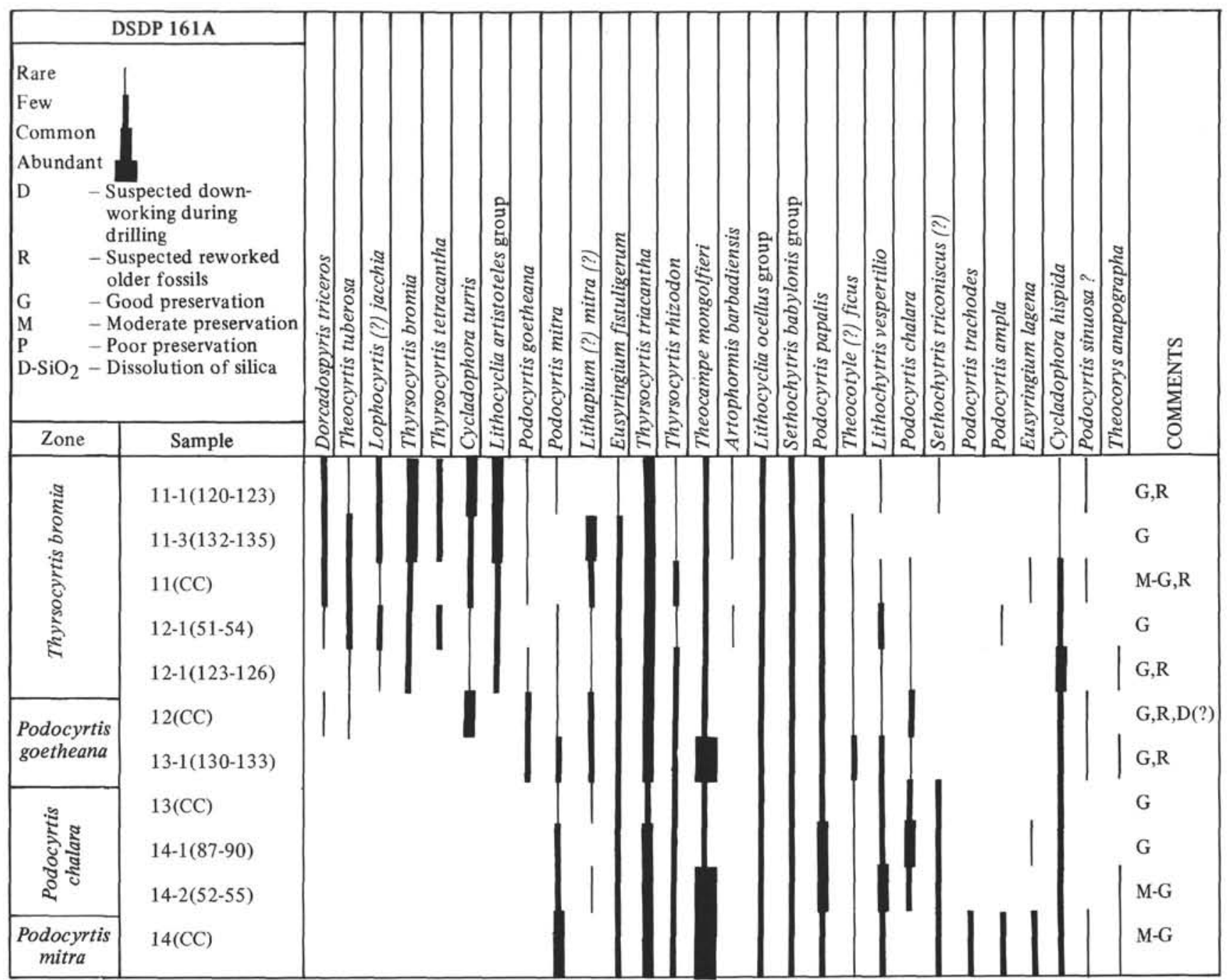

Figure 9. Concluded.

Genus LOPHOCYRTIS Haeckel

Lophocyrtis Haeckel, 1887, p. 1410. Type species (designated by Campbell, 1954, p. 134).

Ecyrtidium stephanophorum Ehrenberg (1873, p. 233; 1875, pl. 8, fig. 14).

\section{Lophocyrtis (?) jacchia (Ehrenberg)} (Plate 2, Figure 6)

Thyrsocyrtis jacchia, Ehrenberg, 1873, p. 261; 1875, pl. 12, fig. 7.

Lophocyrtis (?) jacchia (Ehrenberg); Riedel and Sanfilippo, 1970, p. 530.

\section{Genus LYCHNOCANOMA Haeckel}

Lychnocanoma, Haeckel, 1887, p. 1229. Type species (designated by Campbell, 1954, p. 124) Lychnocanoma clavigerum Haeckel, 1887, p. 1230, pl. 61, fig. 4. Genus as used by Foreman, in press.

\section{Lychnocanoma bipes (Riedel) \\ (Plate 6, Figure 1)}

Lychnocanium bipes, Riedel, 1959, p. 294, pl. 2, figs. 5, 6.

Lychnocanoma bipes (Riedel), Foreman, in press.

\section{Genus PHORMOCYRTIS Haeckel}

Phormocyrtis Haeckel, 1887, p. 1368. Type species (designated by Campbell, 1954, p. 134) Phorriocyrtis longicornis Haeckel (1887, p. 1370, pl. 69 , fig. 15 ).

\section{Phormocyrtis striata Brandt}

Phormocyrtis striata Brandt, 1935, in Wetzel, 1935, p. 55, pl. 9, fig. 12. Genus PTEROCANIUM Ehrenberg

Pterocanium Ehrenberg, 1847a, chart to p. 385. Type species (indicated by Campbell, 1954, p. 130) Pterocanium proserpinae Ehrenberg (1858, p. 39; 1872b, p. 11, fig. 22). Genus as used by Riedel and Sanfilippo, 1970, p. 529.

Pterocanium prismatium, Riedel

Pterocanium prismatium Riedel, 1957, p. 87, pl. 3, figs. 4, 5; emend. Riedel and Sanfilippo, 1970, p. 529.

Pterocanium praetextum (Ehrenberg)

Lychnocanium praetextum Ehrenberg, 1872a, p. 316.

Pterocanium praetextum (Ehrenberg); Haeckel, 1887, p. 1330; Riedel, 1957, p. 86, pl. 3, figs. 1-3.

\section{Genus SETHOCHYTRIS Haeckel}

Sethochytris Haeckel (1881, p. 433). Type species (indicated by Campbell, 1954, p. 124) Sethochytris triconiscus Haeckel (1887, p. 1239, pl. 57, fig. 13).

\section{Sethochytris babylonis (Clark and Campbell) group}

Dictyophimus babylonis Clark and Campbell, 1942, p. 67, pl. 9, figs. 32, 36. 


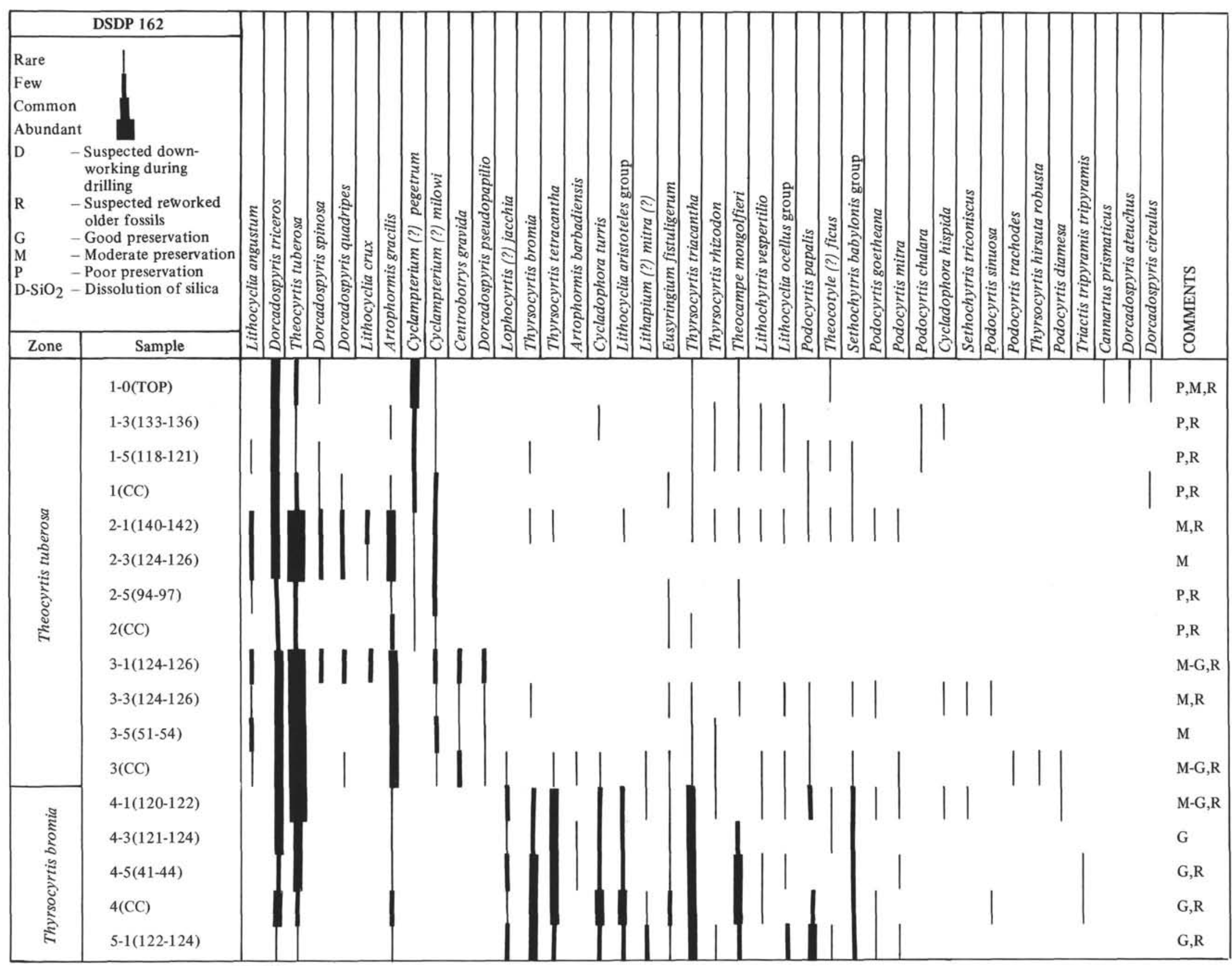




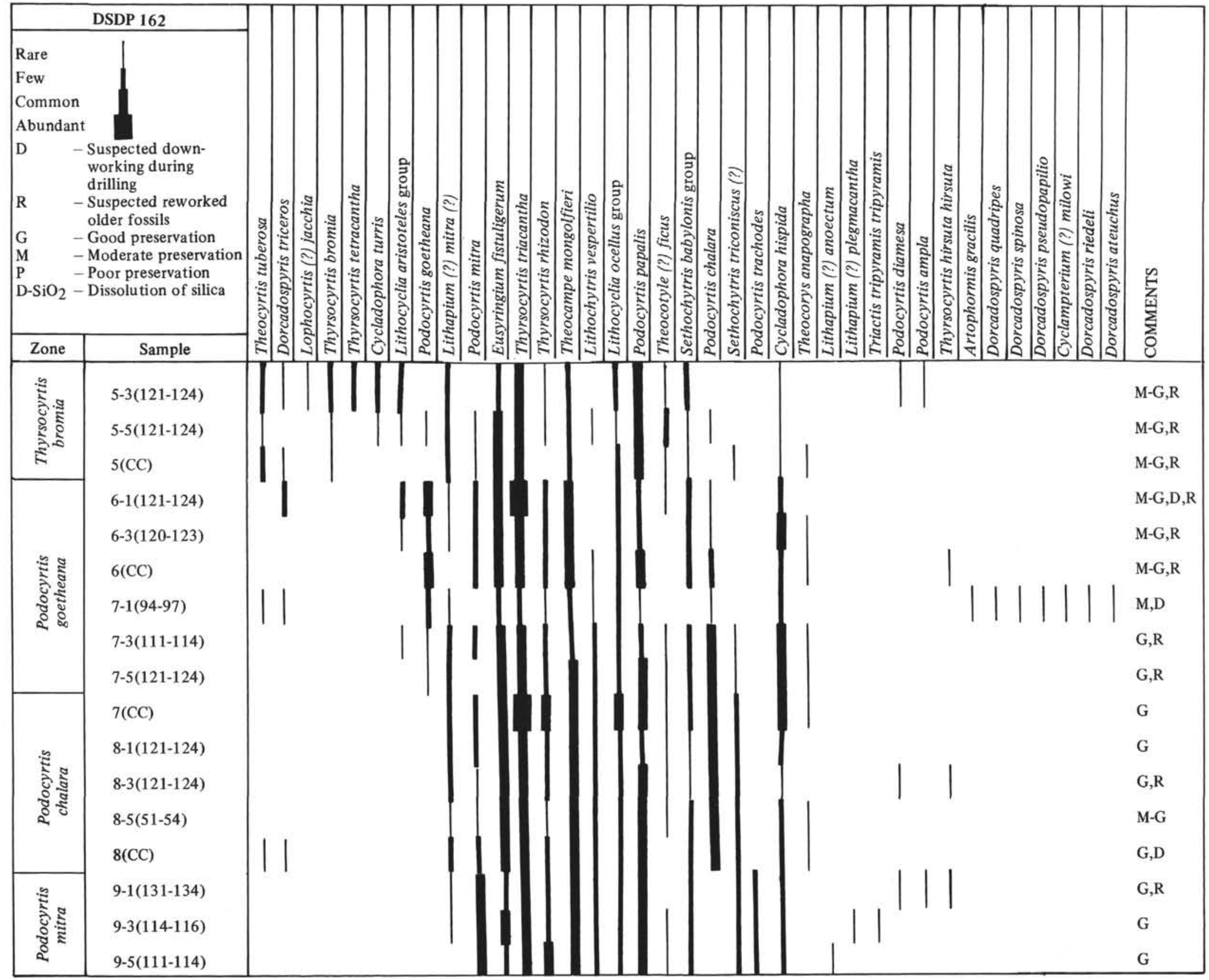

Figure 10. Continued. 


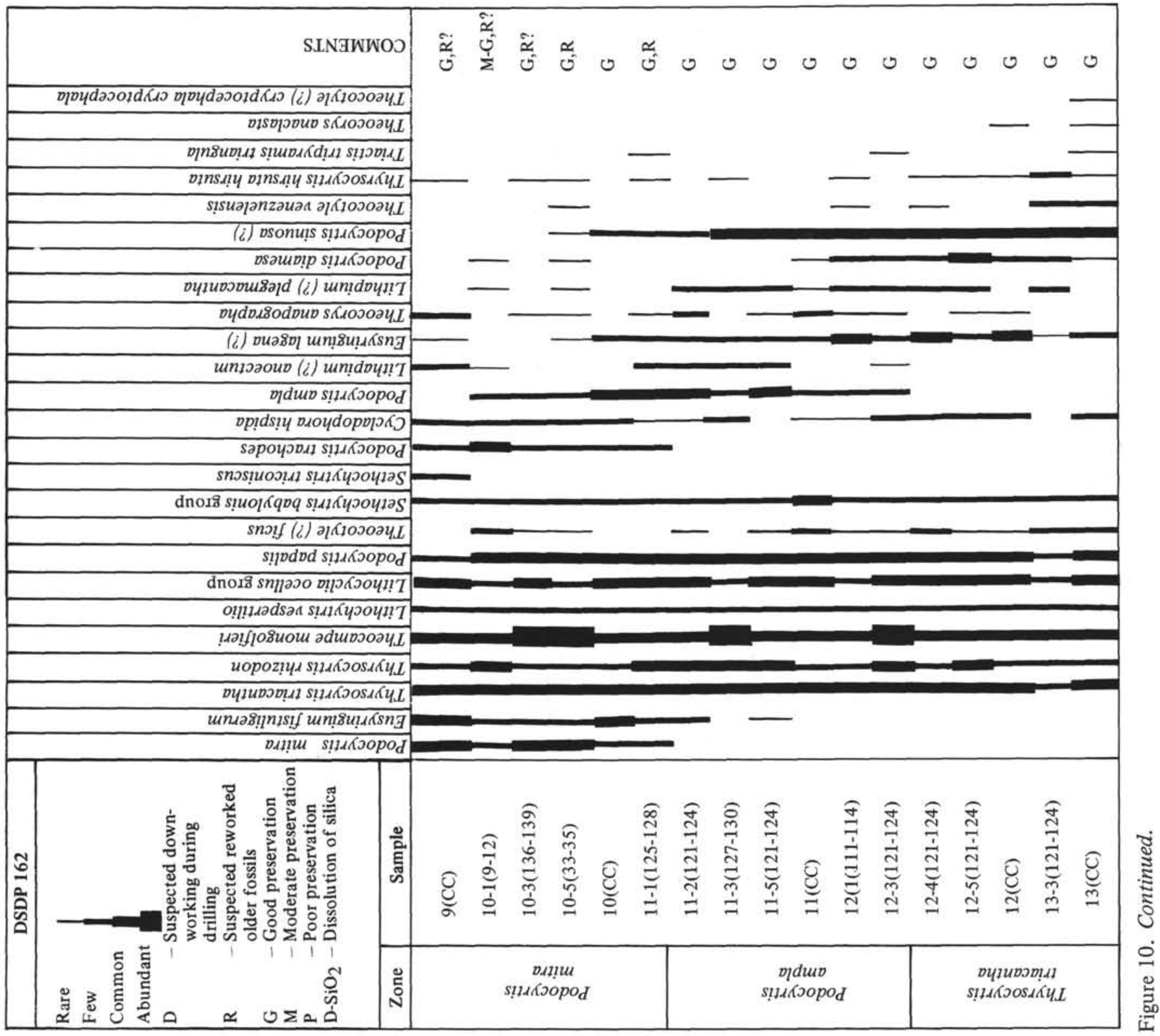

Lychnocanium lucerna Ehrenberg, 1847b, fig. 5; 1854, pl. 36, fig 6; 1873 , p. 244.

Sethochytris babylonis (Clark and Campbell) group as used by Riedel and Sanfilippo, 1970, pl. 9, figs. 1-3.

Sethochytris triconiscus Haeckel (?)

Sethochytris triconiscus Haeckel, 1887, p. 1239, pl. 57, fig. 13; Riedel and Sanfilippo, 1970, pl. 9, fig. 6 .

\section{Genus STICHOCORYS Haeckel}

Stichocorys Haeckel, 1881, p. 438. Type species (indicated by Campbell, 1954 , p. 140). Stichocorys wolffii Haeckel (1887, p. 1479, pl. 80, fig. 10).
Stichocorys delmontensis (Campbell and Clark)

(Plate 9, Figure 1)

Eucyrtidium delmontense, Campbell and Clark, 1944, p. 56, pl. 7., figs. 19, 20; Riedel, 1952, p. 8, pl. 1, fig. 3; Riedel 1957, p. 93.

Stichocorys delmontensis (Campbell and Clark); Riedel and Sanfilippo, 1970, p. 530, pl. 14 , fig. 6 .

\section{Stichocorys diploconus (Haeckel)}

Cyrtocapsa diploconus Haeckel, 1887, p. 1513, pl. 78, fig. 6 .

Stichocorys diploconus (Haeckel), Sanfilippo and Riedel, 1970, p. 451, pl. 1 , figs. 31-32. 


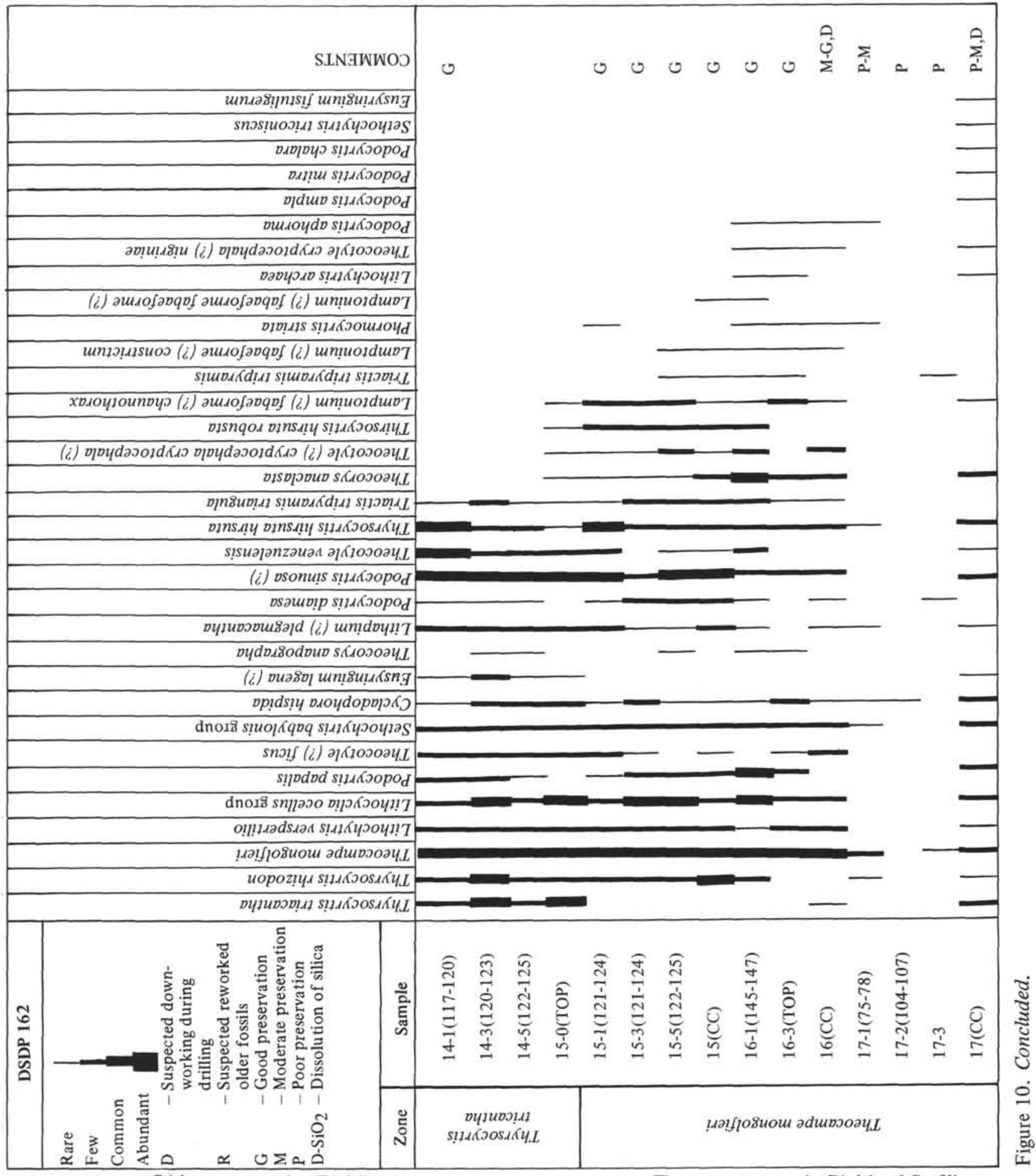

Stichocorys peregrina (Riedel)

(Plate 9, Figures 2, 3)

Eucyrtidium elongatum peregrinum Riedel, 1953, p. 812, pl. 85, fig. 2. Stichocorys peregrina (Riedel); Riedel and Sanfilippo, 1970, p. 530. Stichocorys wolffii Haeckel

Stichocorys wolffii Haeckel, 1887, p. 1479, pl. 80, fig. 10; Riedel, 1957, p. 92 , pl. 4 , figs. 6.7 .

$$
\text { Genus THEOCORYS Haeckel }
$$

Theocorys Haeckel, 1881, p. 434. Type species (indicated by Campbell, 1954 , p. 134). Theocorys morchellula Rust (1885, p. 308, pl. 37, fig. 6). Genus as used by Riedel and Sanfilippo, 1970, p. 530 .

$$
\text { Theocorys anaclasta Riedel and Sanfilippo }
$$

Theocorys anaclasto Riedel and Sanfilippo, 1970, p. 530, pl. 10, figs. 2, 3.
Theocorys anapographa Riedel and Sanfilippo

(Plate 2, Figure 2)

Clathrocyclas sp. Nigrini, 1970 , p. 403 , pl. 2, fig. 3 .

Theocorys anapographa Riedel and Sanfilippo, 1970, p. 530, pl. 10, fig. 4. Genus THEOCOTYLE Riedel and Sanfilippo

Theocotyle Riedel and Sanfilippo, 1970, p. 524. Types species Theocotyle venezuelensis, Riedel and Sanfilippo.

Theocotyle cryptocephala cryptocephala (Ehrenberg) (?)

Eucyrtidium cryptocephalum Ehrenberg, 1873, p. 227; 1875, pl. 11, fig. 11.

Theocotyle cryptocephalum (Ehrenberg) (?) Riedel and Sanfilippo, 1970, pl. 6 , figs. 7,8 . 


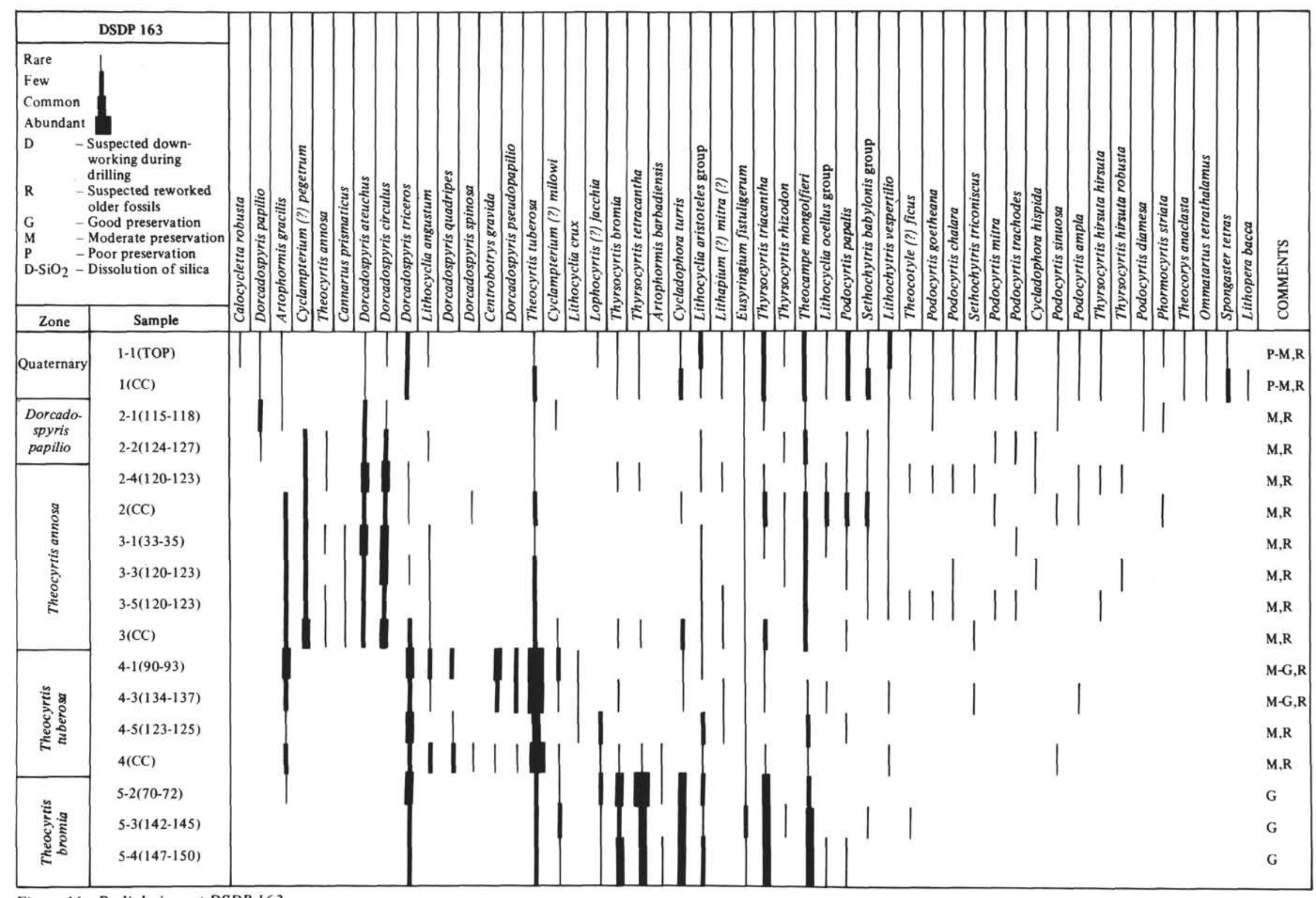

Figure 11. Radiolarians at DSDP 163. 


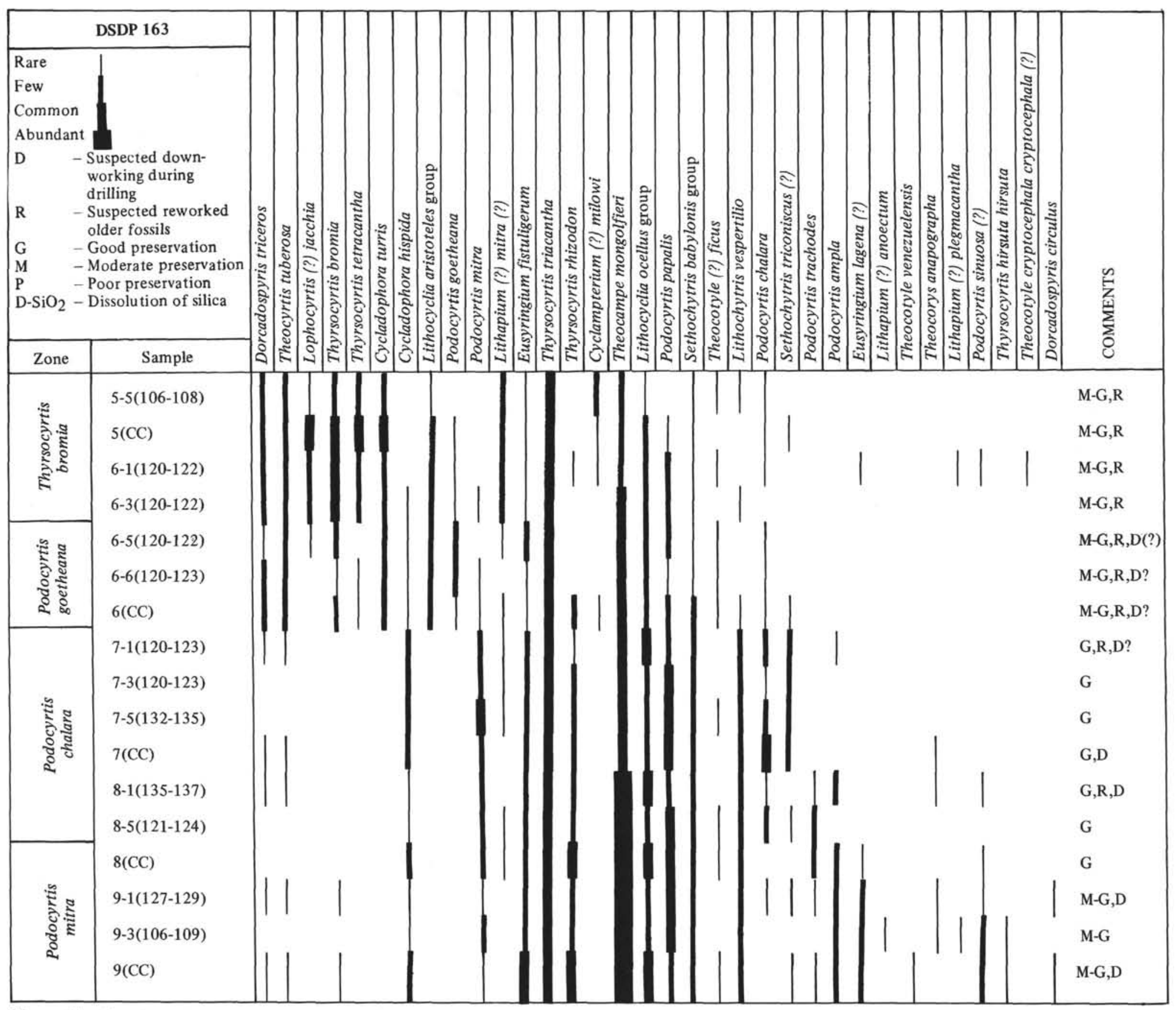

Figure 11. Continued. 


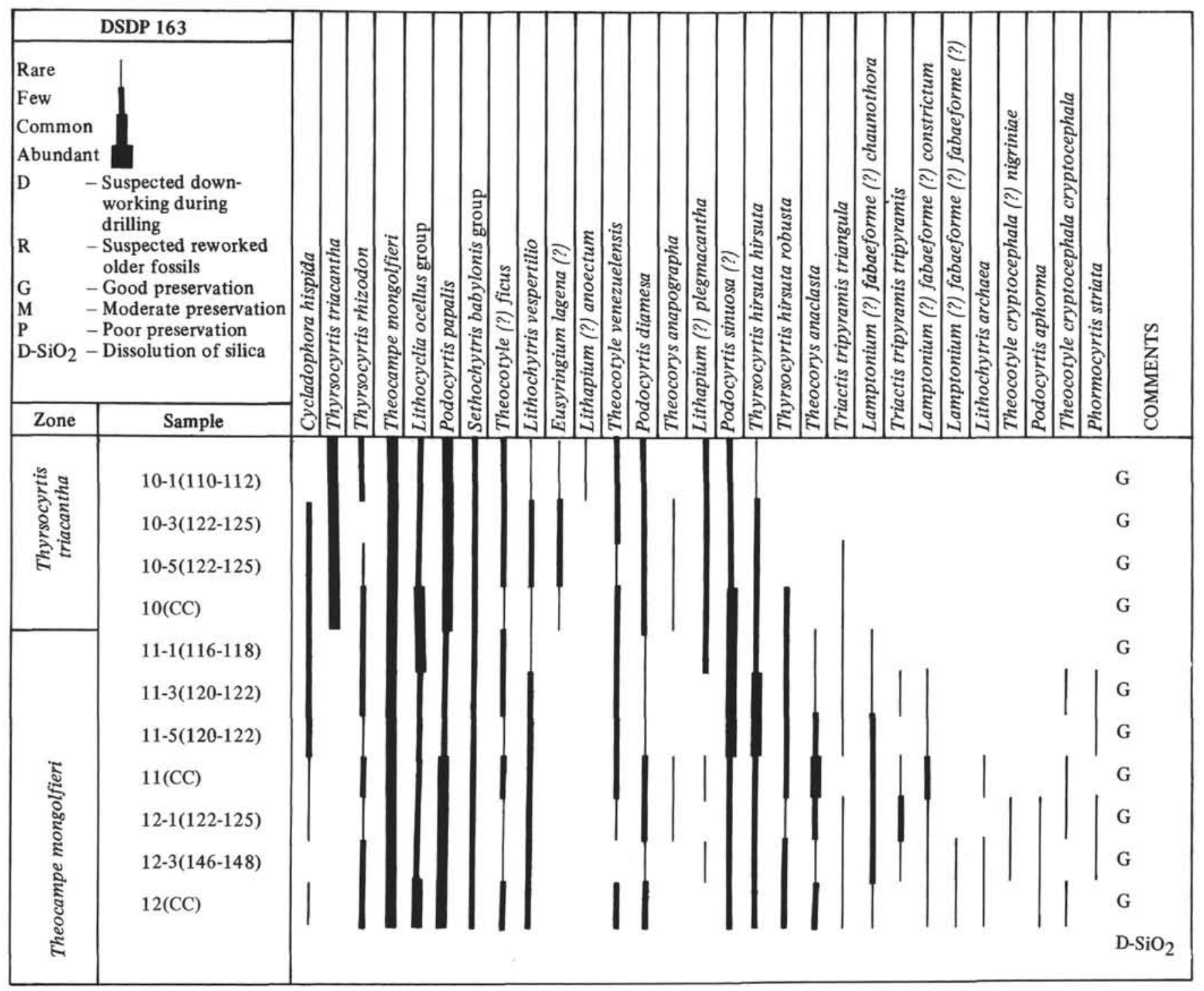

Figure 11. Concluded.

Theocotyle cryptocephala (?) nigrinae Riedel and Sanfilippo

Theocotyle cryptochephala (?) nigrinae Riedel and Sanfilippo, 1970, pl. 6, figs. 5, 6 .

Theocotyle venezuelensis Riedel and Sanfilippo

Theocotyle venezuelensis Riedel and Sanfilippo, 1970, pl. 6, figs. 9, 10; pl. 7 , figs. $1,2$.

Theocotyle (?) ficus (Ehrenberg)

Eucyrtidium ficus Ehrenberg, 1873, p. 228; 1875, pl. 11, fig. 19.

\section{Genus THYRSOCYRTIS Ehrenberg}

Thyrsocyrtis Ehrenberg, 1847b, chart to p. 54 . Type species (indicated by Campbell, 1954, p. 130) Thyrsocyrtis rhizodon Ehrenberg (1873, p. 262 ; 1875 , pl. 12, fig. 1).

Podocyrtidium Haeckel, 1887, p. 1337. Type species (indicated by Campbell, 1954, p. 130) Podocyrtis tripodiscus Haeckel (1887), p. 1338, pl. 72 , fig. 4.

Thyrsocyrtis Ehrenberg as used by Riedel and Sanfilippo, 1970, p. 525. Thyrsocyrtis rhizodon Ehrenberg

Thyrsocyrtis rhizodon Ehrenberg, 1873, p. 262; 1875, pl. 12, fig. 1; Riedel and Sanfilippo, 1970, pl. 7, figs. 6, 7.

Thyrsocyrtis hirsuta hirsuta (Krasheninnikov)

Podocyrtis hirsutus Krasheninnikov, 1960, p. 300, pl. 3, fig. 16.

Thrysocyrtis hirsuta hirsuta Riedel and Sanfilippo, 1970, pl. 7, figs. 8, 9. Thyrsocyrtis hirsuta robusta Riedel and Sanfilippo

Thyrsocyrtis hirsuta robusta Riedel and Sanfilippo, 1970, pl. 8, fig. 1.
Thyrsocyrtis triacantha (Ehrenberg)

(Plate 2, Figures 7, 8)

[?] Podocyrtis cothurnata Ehrenberg, 1854, pl. 36, fig. 21; 1873, p. 250; 1875 , pl. 14 , fig. 1.

Podocyrtis triacantha Ehrenberg, 1873, p. 254; 1875, pl. 13, fig. 4.

Thyrsocyrtis triacantha (Ehrenberg); Riedel and Sanfilippo, 1970, pl. 8,

figs. 2,3 ,

Remarks: The typical Thyrsocyrtis triacantha is shown in Plate 2, Figure 7. In Figure 8 a variant is shown. This variant is distinguished by the lack of the distal rim, the more elongated, less inflated abdomen, and its feet do not curve outward but are generally short and straight downward. This variant occurs briefly in the upper part of the Th. triacantha range, at the beginning of the Th. bromia Zone and may be an intermediate form that gives rise to Thyrsocyrtis tetracantha. Thyrsocyrtis tetracantha (Ehrenberg)

(Plate 2, Figures 4, 5)

Podocyrtis tetracantha Ehrenberg, 1873, p. 254; 1875, pl. 13, fig. 2.

Thyrsocyrtis tetracantha (Ehrenberg); Riedel and Sanfilippo, 1970, p.

Remarks: The specimen shown in Plate 2, Figure 4, is an early specimen of Th. tetracantha. It seems likely that this form developed from the Thyrocyrtis sp. Th. triacantha pictured in Plate 2, Figure 8 . This form of Th. tetracantha is observed in the lower part of the Th. bromia Zone. The more typical Thyrocyrtis tetracantha (More 1971, pl. 4, fig. 3) occurs only in the upper part of this zone. Thyrsocyrtis bromia Ehrenberg (Plate 3, Figures 1-6)

Thyrsocyrtis bromia Ehrenberg, 1873, p. 260;1875, pl. 12, fig. 2.

Remarks: Plate 3, Figures 1, 2, 4 show the more typical forms of Thyrsocyrtis bromia. There are several transitional forms with a heavier 
and more inflated abdomen (Plate 3, Figures 3, 6); these forms range higher in the zone than does the typical Th. bromia. The form of Plate 3, Figure 5 cooccurs with Th. bromia in the lower part of its range. It may represent a transitional form from Th. rhizodon to Th. bromia, although the large abdominal pores and the apparent presence of more than three short feet that extend immediately from the abdominal meshwork suggest that it may stand between Th. triacantha and Th. tetracantha.

A distinct species, which apparently is restricted to the lower $T h$. bromia Zone, is illustrated in Figures 7 and 8 . This is a conical form, slightly thorny, with two very distinct strictures; cephalis subspherical with a large apical horn, thorax ovate spherical with regular subcircular pores, usually thorny; abdomen ovate, with large subcircular irregular pores and a narrow distal rim which encloses a wide aperture. No feet are present.

This form may be useful for stratigraphic work because it is short ranging and occurs in that part of the Upper Eocene interval where the presently used zonation has been shown to be somewhat ambiguous.

\section{Family PTEROCORYIDAE Haeckel}

Pterocoryidae Haeckel, 1881, emend. Riedel, $1967 \mathrm{.}$

\section{Genus ANTHOCYRTIDIUM Haeckel}

Anthocyrtidium Haeckel, 1881, p. 431; 1887, p. 1278. Type species (designated by Nigrini, 1967, p. 56) Anthocyrtidium ophirense (Ehrenberg)(1872b, p. 285, pl. 9, fig. 13) $(=$ A. cineraria Haeckel $)(1887$, p. 1278 , pl. 62 , fig. 16 ).

Anthocyrtidium angulare Nigrini (Plate 10, Figure 5)

Anthocyrtidium angulare Nigrini, 1971, p. 445 , pl. 34.1 , figs. $3 a, 6$.

\section{Genus CALOCYCLETTA Haeckel}

Calocycletta Haeckel, 1887, p. 1381. Type species (designated by Campbell, 1954, p. 132) Calocyclas veneris Haeckel (1887, p. 1381, pl. 74 , fig. 5).

Calocycletta parva Moore

(Plate 7, Figures 1, 2)

Calocycletta parva Moore, in press.

\section{Calocycletta robusta, Moore}

(Plate 7, Figure 4)

Calocyclas cf. C. virginis, Moore, 1968, p. 104, pl. 7, figs. 4a, 4b.

Calocycletta robusta Moore, 1971, p. 743, pl. 10, figs. 5, 6.

Calocycletta serrata Moore

(Plate 7, Figure 5)

Calocycletta serrata Moore, in press.

\section{Calocycletta virginis (Haeckel)}

(Plate 7, Figure 6, 7)

Calocyclas virginis Haeckel, 1887, p. 1381, pl. 74, fig. 4; Riedel, 1959, p. 295 , pl. 2, fig. 8.

Calocycletta virginis (Haeckel); Riedel and Sanfilippo, 1970, p. 535, pl. 14, fig. 10.

\section{Calocycletta costata (Riedel)}

(Plate 7, Figure 8)

Calocyclas costata Riedel, 1959, p. 296, pl. 2, fig. 9.

Calocycletta costata (Riedel), Riedel and Sanfilippo, 1970, p. 535, pl. 14, fig. 12.

\section{Calocycletta caepa Moore}

(Plate 7, Figure 9)

Calocycletta sp. of C. virginis Haeckel - Moore, 1968, p. 104, pl. 7, figs. la, b.

Calocycletta caepa Moore, in press.

Genus PODOCYRTIS Ehrenberg

Podocyrtis Ehrenberg, 1847a, chart to p. 385. Type species (indicated by Campbell, 1954, p. 130) Podocyrtis papalis Ehrenberg (1847b, fig. 2; 1854 , pl. 36 , fig. $23 ; 1873$, p. 251 ).

\section{Subgenus PODOCYRTIS Ehrenberg}

Podocyrtis (Podocyrtidium) Haeckel, 1887, p. 1344, Podocyrtis (Podocyrtis) in Campbell, 1954, p. 130.

\section{Podocyrtis (Podocyrtis) papalis Ehrenberg}

Podocyrtis papalis, Ehrenberg, 1847b, fig. 2; 1854, pl. 36, fig. 23; 1873, p. 251.

Podocyrtis fasciata Clark and Campbell, 1942, p. 80, pl. 7, figs. 29, 33.

Podocyrtis (Podocyrtis) papalis Riedel and Sanfilippo, 1970, p. 533, pl. 11, fig. 1.

Podocyrtis (Podocyrtis) diamesa Riedel and Sanfilippo

Podocyrtis (Podocyrtis) diamesa Riedel and Sanfilippo, 1970, p. 533, pl. 12, figs. 4-6.

Podocyrtis (Podocyrtis) ampla Ehrenberg

Podocyrtis (?) ampla Ehrenberg, 1873, p. 248; 1875, pl. 16, fig. 7. Podocyrtis (Podocyrtis) ampla Ehrenberg; Riedel and Sanfilippo, 1970, p. 533 , pl. 12 , figs. 7,8 .

\section{Subgenus LAMPTERIUM Haeckel}

Lampterium Haeckel, 1881, p. 434. Type species (indicated by Campbell, 1954, p. 132) Cycladophora goetheana Haeckel (1887, p. 1376, pl. 65, fig. 5)

Lampterium Haeckel; Riedel and Sanfilippo, 1970, p. 534.

Podocyrtis (Lampterium) aphorma Riedel and Sanfilippo

Podocyrtis (Lampterium) aphorma Riedel and Sanfilippo, 1970, p. 534, pl. 11 , fig. 2.

Podocyrtis (Lampterium) sinuosa Ehrenberg (?)

[?] Podocyrtis sinuosa Ehrenberg, 1873, p. 253; 1875, pl. 15, fig. 5.

Podocyrtis sinuosa Ehrenberg (?); Riedel and Sanfilippo, 1970 p. 534, pl. 11, figs. 3, 4 .

\section{Podocyrtis (Lampterium) mitra Ehrenberg}

Podocyrtis mitra Ehrenberg, 1854, pl. 36, fig. 1320; 1873, p. 251;[non Ehrenberg, 1875, pl. 15, fig. 4].

Podocyrtis (Lamptonium) mitra Ehrenberg; Riedel and Sanfilippo, 1970, p. 534 , pl. 11 , figs. 5,6 .

Podocyrtis (Lampterium) trachodes Riedel and Sanfilippo

Podocyrtis (Lampterium) trachodes Riedel and Sanfilippo, 1970, p. 535, pl. 11, fig. 7; pl. 12, fig. 1.

Podocyrtis (Lampterium) chalara, Riedel and Sanfilippo

[?] Podocyrtis (?) sp. Bury, 1862, pl. 12, fig. 2.

Podocyrtis (Lampterium) chalara Riedel and Sanfilippo, 1970, p. 535, pl 12 , figs. 2,3

Podocyrtis (Lampterium) goetheana (Haeckel)

Cycladophora goetheana Haeckel, 1887, p. 1376, pl. 65, fig. 5 .

Podocyrtis (Lampterium) goetheana (Haeckel); Riedel and Sanfilippo, 1970 , p. 535 , pl. 65 , fig. 5 .

\section{Genus THEOCORYTHIUM Haeckel}

Theocorythium Haeckel, 1887, p. 1416. Type species (designated by Campbell, 1954, p. 134) Theocorys dianae Haeckel, 1887, p. 1416, pl. 69, fig. 11

\section{Theocorythium vetulum Nigrini} (Plate 10, Figures 11, 12)

Theocorythium vetulum Nigrini, 1971, p. 447, pl. 34.1, figs. 6a, b.

Theocorythium trachelium trachelium (Ehrenberg) (Plate 10, Figures 8, 9)

Eucyrtidium trachelius Ehrenberg, 1872b, p. 293, pl. 7, fig. 8. Calocyclas amicae Haeckel, 1887, p. 1382, pl. 74, fig. 2. Calocyclas amicae Haeckel, Hays, 1965, p. 178, pl. 3, fig. 9.

Theocorythium trachelium trachelium Ehrenberg, Nigrini, 1967, p. 79, pl. 8, fig. 2; pl. 9, fig. 2. 


\section{Genus THEOCYRTIS Heackel}

Theocyrtis Haeckel, 1887, p. 1405. Type species (designated by Campbell, 1954, p. 134) Eucyrtidium barbadense Ehrenberg (1873, p. 226; 1885, pl. 9, fig. 7).

Theocyrtis tuberosa Riedel

Theocyrtis tuberosa Riedel, 1959, p. 298, pl. 2, figs. 10, 11.

Theocyrtis tuberosa Riedel, Moore, 1971, p. 743, pl. 5, figs. 5, 6.

Theocyrtis annosa (Riedel)

(Plate 5, Figure 10)

Phormocyrtis annosa Riedel, 1959, p. 295, pl. 2, fig. 7.

Theocyrtis annosa (Riedel); Riedel and Sanfilippo, 1970, p. 535, pl. 15, fig. 9.

Family ARTOSTROBIIDAE Riedel

Artostrobiidae, Riedel, 1967a, p. 148.

Genus THEOCAMPE Haeckel

Theocampe Haeckel, 1887 , p. 1422 . Type species (designated by Campbell, 1954, p. 134). Dictyomitra ehrenbergi Zittel (1876, p. 82 , pl. 2, fig. 5 ).

Theocampe mongolfieri (Ehrenberg)

Eucyrtidium mongolfieri Ehrenberg, 1854, pl. 36, fig. 18B; 1873, p. 230; 1873 , pl. 10, fig. 3 .

Sethamphora mongolfieri (Ehrenberg), Haeckel, 1887, p. 1251.

Theocampe mongolfieri (Ehrenberg), Burma, 1959, p. 329.

Family CANNOBOTRYIDAE

Cannobotryidae Haeckel, 1881, emend. Riedel, 1967b, p. 296.

Genus ACROBOTRYS Haeckel

Acrobotrys Haeckel, 1881, p. 440. Type species (indicated by Campbell, 1954, p. 144) Acrobotrys monosolenia Haeckel (1887, p. 1114).

Acrobotrys tritubus Riedel

Acrobotrys tritubus Riedel, 1957, p. 80, pl. 1, fig. 5.

Genus CENTROBOTRYS Petrushevskaya

Centrobotrys Petrushevskaya, 1965, p. 113.

Centrobotrys gravida Moore

(Plate 5, Figure 6)

Centrobotrys gravida Moore, 1971, p. 744, pl. 5, fig. 8.

\section{COMMENTS ON PHYLOGENY}

In the radiolarian chapters from Legs 4,7 , and 8 of the Deep-Sea Drilling Project, a large body of data enabled Riedel and Sanfilippo $(1970,1971)$ and Moore (1971) to propose a number of evolutionary lineages. This report merely strengthens the case of the lineages and no conscious attempt was made to expand them. However, the radiolarian data from Leg 16 allows for some additional comments.

\section{Lithocyclia angustum-Ommatartus tetrathalamus}

This is the longest and best documented series of all the radiolarian evolutionary lineages known at present, consisting of fourteen species, and it ranges from the early Oligocene to Recent. An additional form, here identified as Cannartus sp. A (Plate 5, Figures 1, 2) and also observed by Riedel and Sanfilippo (1971, pl. 2B, figs. 9, 10) occurs regularly, although it is rare, in nearly all samples from the Upper Oligocene to the Middle Miocene. This is a slender, elongate, sometimes hirsute form with a distinct equatorial constriction and short, well-developed polar columns. In most forms observed there seem to be a few small protuberances present, arising in the equatorial plane. This form first appears in the Lychnocanoma bipes Zone, shortly after the first appearance of Cannartus tubarius. As yet it is not known if this species belongs in the direct lineage between Cannartus prismaticus and Cannartus tubarius or Cannartus violina, or if it is an offshoot of the main lineage after Cannartus tubarius.

\section{Calocycletta parva-Calocycletta caepa}

This lineage, described in detail by Moore (in press), commences with Calocycletta parva in the Late Oligocene and proceeds through Calocycletta robusta, C. virginis, to terminate with $C$. caepa in the late Miocene. Two other species, Calocycletta serrata and C. costata, developed from respectively $C$. robusta and $C$. virginis, but apparently are not in the direct lineage. As stated by Moore no obvious ancestor to Calocycletta parva could be found.

In the course of the present investigation a species, Calocycletta cf. C. parva (Plate 7, Figure 3), was observed in samples from the Lower Oligocene and the lower Upper Oligocene, thus occurring prior to and coincident with $C$. parva. This species is rather thin walled and delicate, and its rare occurrence may be attributed to its probable sensitivity to corrosion. Further work needs to be done to establish a relationship between this species and $C$. parva.

Theocorythium vetulum-Theocorythium trachelium trachelium

This lineage includes only two taxa, and is of uncertain origin. Th. trachelium trachelium co-occurs with Th. trachelium dianae, although the latter apparently is more common in cold water faunas (Nigrini, 1967).

\section{CRETACEOUS RADIOLARIA}

Below 162 meters in Hole 163 and in the single core at 140 to 144 meters from Hole $163 \mathrm{~A}$, sediments containing Cretaceous radiolarians were cored and recovered. The radiolarians are generally sparse and their preservation is very poor. The catcher sample of Core 27 yielded by far the most diverse and best preserved fauna and most of the specimens illustrated in Plate 1 come from this sample. Because of the generally poor preservation, identification of the forms is difficult and only rarely could be established to the genus level.

Fragments of members of the following families and subfamilies were observed throughout the section: Actinommidae Haeckel, Saturnalinae Deflandre, Neosciadiocapsidae Pessagno.

Of the families listed below, identification to the genus level, and in rare cases to species, could be made on a few specimens.

Family Spongodiscidae Haeckel, 1862, emend. Riedel, 1967b.

In a few samples $(17, \mathrm{CC}, 23, \mathrm{CC}, 27, \mathrm{CC})$ some forms occur, which apparently are related to the genus Amphibrachium Haeckel. The form illustrated on Plate 1, Figure 3, resembles Amphibrachium concentricum Lipman (1960, pl. 28, Figs. 6-7), but the absence of the apophyses and of part of the central structure preclude certain identification. 
Family Pseudoaulophacidae Riedel, 1967a.

In four samples, $16(\mathrm{CC}), 20(\mathrm{CC}), 26(\mathrm{CC})$, and $27(\mathrm{CC})$, there are rare occurrences of Pseudoaulophacus superbus Squinabol. The best preserved specimen (Plate 1, figure 9) occurs in sample 27(CC). Another form (Plate 1, Figure 12) which is present in this sample is tentatively identified as Pseudoaulophacus lenticulatus (White), although several of its diagnostic features can not be recognized.

Family Theoperidae Haeckel, 1881, emend. Riedel, 1967b.

A number of species occur infrequently throughout the Cretaceous cores which are thought to belong to this family. Most of these forms are too poorly preserved to warrant illustration, except for the form illustrated in Plate 1, Figure 8 . This is a small species with four segments, conical except for the last one which is inverted conical to hemispherical and is either closed or with a small porelike aperture. The cephalis carries a short apical spine. Strictures are not pronounced. Thorax and abdomen are thick-walled with irregularly arranged, circular pores. This form occurs in samples from the lower part of the section only.

\section{Genus Dictyomitra Zittel, 1876, sensu Foreman 1968.}

In all samples of the Cretaceous section, specimens of this genus are present. Most of these are incomplete, with several of the distal segments usually missing. The most common specimens have more or less pronounced longitudinal ribs and a relatively smooth outline. In no specimens could any pore pattern be distinguished. The best preserved specimen (Plate 1, Figure 6) resembles Dictyomitra cf. D. multicostata Zittel, but no confident determination can be made.

Genus Lithostrobus, Bütschli, 1882.

In the catcher sample of Core 15 a single specimen was observed which could belong to the genus Lithostrobus Bütschli. This species (Plate 1, Figure 4) has a rather large, conical multicamerate skeleton which widens distally and ends with an open, wide and large, round aperture. The small, upper chamber carries a small, probably conical spine. This species resembles most closely Lithostrobus rostovzevi Lipman (1960, pl. 32, figs. 1-10) but because nothing remains of the pore structure and arrangement, no definite identification to the species level can be made. This is the only sample in which this species was found.

Family Amphipynadacidae Riedel, 1967a. Genus Amphipyndax Foreman, 1966.

Members of this family occur in the catcher samples of Cores 18, 22, 23, and 27. The form illustrated in Plate 1, Figure 10, is comparable with Amphipyndax enesseffi Foreman (1966, figs. 10-11). The specimen pictured in Plate 1, Figure 11, exhibits the divided cephalis, but in this species the transverse partial septum divides the cephalis in two approximately equal chambers. Thorax and abdominal segments are truncated conical, with nodular longitudinal ribs. No pore structure and arrangement could be observed. Although this species does not exhibit the characteristics of Amphipyndax Foreman sensu stricto, it is tentatively assigned to this genus. Sample $27(C C)$ is the only sample in which this species was observed.

Family Artostrobiidae Riedel, 1967b.

Genus Theocampe Haeckel, 1887, emend. Burma, 1959.

Species of this genus occur infrequently in samples from Core 23 on down. Usually they are too poorly preserved to allow confident identification.

\section{Theocampe apicata Foreman Plate 1 Figure 7}

This distinctive form was observed only in the catcher samples of Cores 26 and 27.

Genus Rhopalosyringium Campbell and Clark, 1944, emend. Foreman 1968.

Species of this genus are present in nearly all samples from the Cretaceous section. The most common forms are those illustrated in Plate 1, Figures 1-2, and are very similar to the one pictured by Foreman (1971, pl. 3, figs. 9-10). One rare specimen, only occurring in Sample 23(CC (Plate 1, Figure 5), differs from the others in having an annular to subglobose thorax with pores tending to a longitudinal alignment, an indistinct lumbar stricture, and an abdomen which appears to be cylindrical.

All of the species mentioned above are considered to be of late Cretaceous age, probably Campanian.

\section{REFERENCES}

Berggren, W.A., in press. A Cenozoic time-scale-some implications for regional geology and paleobiogeography. Lethaia.

Burma, B.H., 1959. On the status of Theocampe Haeckel, and certain similar genera. Micropaleontology. 5 (3), 325.

Bury, P.S., 1862. Figures of remarkable forms of Polycystins, or allied organisms, in the Barbados Chalk deposit. Atlas. London. $11 \mathrm{p}$.

Campbell, A.S., 1954. Radiolaria. In Treatise on Invertebrate Paleontology, R.C. Moore (Ed.). (Univ. Kansas Press and Geol. Soc. Am.). Pt. D, Protista 3, 11.

Campbell, A.S. and Clark, B.L., 1944. Miocene radiolarian faunas from southern California. Geol. Soc. Am., Spec. Paper 51.

Clark, B.L. and Campbell, A.S., 1942. Eocene radiolarian faunas from the Mt. Diablo area, California. Geol. Soc. Am., Spec. Paper 39.

Ehrenberg, C.G., 1838. Über die Bildung der Kreidefelsen und des Kreidemergels durch unsichtbare Organismen. Abh. Kgl. Preuss. Akad. Wiss. Berlin. Jahre 1838, 59. 1847a. Über eine halibiolithische, von Herrn R. Schomburgk entdeckte, vorherrschend aus mikroskopischen Polycystinen gebildete, Gebirgsmasse von Barbados. Ber. Kgl. Preuss. Akad. Wiss. Berlin, Jahre 1846, 382 .

1847b. Über die mikroskopischen kieselschaligen Polycystinen als mächtige Gebirgsmasse von Barbados und über das Verhaltniss der aus mehr als 300 neuen Arten bestehenden ganz eigenthümlichen Formengruppe jener Felsmasse zu den jetzt lebenden Thieren und zur Kreidebildung. Eine neue Anregung zur Erforschung des Erdlebens. Ber. Kgl. Preuss. Akad. Wiss. Berlin. Jahre 1847,40 . 
1854. Mikrogeologie. Leipzig(Voss). 374 p. Continuation (1856), 88 p. +1 p. errata.

1860. Über den Tiefgründ des stillen oceans zwischen Californien und den Sandwich-Inseln aus bis 15,600 Fuss Tiefe nach Lieut. Brooke. Monatsber. Kgl. Preuss. Akad. Wiss. Berlin. Jahre 1860, 819.

1861. Über die Tiefgründ-Verhaltnisse des oceans am Eingange der Davisstrasse und bei Island. Monatsber. Kgl. Preuss. Akad. Wiss. Berlin. Jahre 1861, 275.

1872a. Mikrogeologischen Studien als Zusammenfassung der Beobachtungen des kleinsten Lebens der Meeres-Tiefgründe aller Zonen und dessen geologischen Einfluss. Monatsber. $\mathrm{Kgl}$. Preuss. Akad. Wiss. Berlin. Jahre $1872,265$.

$1872 \mathrm{~b}$. Mikrogeologische Studien über das kleinste Leben der Meeres-Tiefgründe aller Zonen und dessen geologischen Einfluss. Abh. Kgl. Akad. Wiss. Berlin. Jahre 1872, 131.

1873. Grössere Felsproben des Polycystinen-Mergels von Barbados mit weiteren Erläuterungen. Ber. Kgl. Preuss. Akad. Wiss. Berlin. Jahre 1873, 213.

1875. Fortsetzung der mikrogeologischen Studien als Gesammt-Uebersicht der Mikroskopischen Paläontologie gleichartig analysirter Gebirgsarten der Erde, mit Specieller Rücksicht auf den PolycystinenMergel von Barbados. Abh. Kgl. Akad. Wiss. Berlin. Jahre $1875,1$.

Foreman, H.P., 1966. Two Cretaceous radiolarian genera. Micropaleontology. 12 (3), 355.

, 1968. Upper Maestrichtian radiolaria of California. Paleontol. Assoc., London, Spec. Paper Paleo. 3. 1971. Cretaceous Radiolaria, Leg 7, Deep Sea Drilling Project. In Winterer, E.L., Riedel, W.R. et al., 1971. Initial Reports of the Deep Sea Drilling Project, Volume VII. Washington (U.S. Government Printing Office). 1673. in press. Radiolaria of Leg 10 with systematics and ranges for the families Amphipyndacidae, Artostrobiidae, and Theoperidae. In Initial Reports of the Deep Sea Drilling Project, Volume X. Washington (U. S. Government Printing Office).

Frezzell, D.L. and Middoor, E.S., 1951. Paleocene Radilaria from Southeastern Missouri. Univ. Missouri, Sch. Mines Mettal. Bull., Tech Ser. 77, 1.

Goll, R.M., 1969. Classification and phylogeny of Cenozoic Trissocyclidae (Radiolaria) in the Pacific and Caribbean Basins. Pt. II. J. Paleontol. 43 (2), 322.

Haeckel, E., 1862. Die Radiolarien (Rhizopoda Radiaria). Berlin (Reimer). 572 p.

1881. Entwurf eines Radiolarien-Systems auf Grund von Studien der Challenger-Radiolarien. Jena, Z. Med. Naturwiss. 15 [New Ser. 8] (3), 418.

1887. Report on the Radiolaria collected by H.M.S. Challenger during the years 1873-76. Rept. Voyage Challenger, Zool. 18, Pt. I, II. Edinburgh. 1803 p.

Hays, J.D., 1965. Radiolaria and late Tertiary and Quaternary history of Antarctic Seas. In Biology of Antarctic Seas II. Am. Geophys. Union. Antarctic Research Ser. 5, 124.

, 1970. Stratigraphy and evolutionary trends of Radiolaria in North Pacific deep-sea sediments. Geol. Soc. Am. Mem. 126, 185.

Kling, S.A., 1970. Radiolaria, Leg 6, Deep Sea Drilling Project. In Fischer, A.G., Heezen, B.C. et al., 1970. Initial Reports of the Deep Sea Drilling Project, Volume VI. Washington (U. S. Government Printing Office). 1069.

Krasheninnikov, V.A., 1960. Nekotorye Radiolyarii Nizhnego i Srednego Eotsena Zapadnogo Predkavkazya. Min. Geol. i. Okhr. Nedr. SSSR Vses. Nauch. - Issled. Geol. Neft. Inst. (16), 271.
Lipman, R.Kh., 1952. Data on the monographic study of the radiolarians of the upper Cretaceous deposits of the Russian Platform, Trans. All-Union Geol. Sci. Res. Inst. 1960. In Stratigraphy and Fauna of the Cretaceous deposits in the Western Siberian Lowland, A.E. Glazunova, Editor-in-Chief. Vs. Nauch. - Issled. Geol. Inst., Tr., (New Ser.), 29, 124.

Moore, T.C., Jr., 1968. Deep sea sedimentation and cenozoic stratigraphy in the central equatorial Pacific. Ph.D. dissertation, Univ. Calif., San Diego. 1971. Radiolaria, Leg 8, Deep Sea Drilling Project. In Tracey, J.I., Jr., Sutton, G.H. et al., 1971. Initial Reports of the Deep Sea Drilling Project, Volume VIII. Washington (U. S. Government Printing Office). 727.

in press. Mid-Tertiary evolution of the Radiolarian Genus Calocycletta. Micropaleontology.

Müller, J., 1855. Über die im Hafen von Messina beobachteten Polycystinen. Ber. Kgl. Preuss. Akad. Wiss. Berlin. Jahre 1855. 671.

Nakaseko, K., 1963. Neogene Cyrtoidea (Radiolaria) from the Isozaki Formation in Ibaraki Prefecture, Japan. Osaka Univ. Sci. Rept. 12 (2), 165.

Nigrini, C., 1967. Radiolaria in pelagic sediments from the Indian and Atlantic Oceans. Bull. Scripps Inst. Oceanogr. 11. 1970. Radiolaria, Leg 2, Deep Sea Drilling Project. In Peterson, M.N.A., Edgar, N.T. et al., 1970. Initial Reports of the Deep Sea Drilling Project, Volume II. Washington (U. S. Government Printing Office). 401.

1971. Radiolarian zones in the Quaternary of the equatorial Pacific Ocean. In The Micropaleontology of Oceans, Funnel, B.M. and Riedel, W.R., (Eds.). Cambridge (Cambridge Univ. Press). 443.

Petrushevskaya, M.G., 1965. Peculiarities of the construction of the skeleton of Botryoid Radiolarians (order Nasellaria). Tr. Zool. Instit., Akad. Nauk SSSR 35, 79.

Riedel, W.R., 1952. Tertiary Radiolaria in Western Pacific sediments. Goteborgs Kgl. Vetensk.-och Vitterhets-Samhalles Handl. Folj. 7, B, 6 (3), 1.

1953. Mesozoic and Late Tertiary Radiolaria of Rotti. J. Paleontol. 27 (6), 805.

1957. Radiolaria: a preliminary stratigraphy. Rept. Swedish Deep-Sea Exped. 6 (3), 59.

1959. Oligocene and Lower Miocene Radiolaria in tropical Pacific sediments. Micropaleontology. 5 (3), 285 .

, 1967a. Some new families of Radiolaria. Proc. Geol. Soc. London. 1640, 148.

1967b. Subclass Radiolaria. In The Fossil Record, Harland, W.B. et al. (Eds.). London (Geol. Soc. London). 291.

1971. Systematic classification of polycystine Radiolaria. In The Micropaleontology of Oceans. Funnell, B.M. and Riedel, W.R., (Eds.). Cambridge (Cambridge Univ. Press). 649.

Riedel, W.R. and Funnell, B.M., 1964. Tertiary sediment cores and microfossils from the Pacific Ocean floor. Quart. J. Geol. Soc. London. 120, 305.

Riedel, W.R. and Sanfilippo, A., 1970. Radiolaria, Leg 4, Deep Sea Drilling Project. In Bader, R.G., Gerard, R.D. et al., 1970. Initial Reports of the Deep Sea Drilling Project, Volume IV. Washington (U. S. Government Printing Office). 503.

1971. Cenozoic Radiolaria from the western tropical Pacific, Leg 7, Deep Sea Drilling Project. In Winterer, E.L., Riedel, W.R. et al., 1971. Initial Reports of the Deep Sea Drilling Project, Volume VII. Washington (U. S. Government Printing Office). 1529. 
Rust, D., 1885. Beiträge zur Kenntniss der fossilen Radiolarien aus Gesteinen des Jura. Palaeontographica. 31 (3), 273.

Sanfilippo, A. and Riedel, W.R., 1970. Post-Eocene "closed" theoperid radiolarians. Micropaleontology. 16 (4), 446.

Sutton, H.J., 1896. Radiolaria: a new genus from Barbados. Am. Monthly Microsc. J. 71 (194), 61.
Wetzel, O., 1935. Die Mikropalaeontologie des Heiligenhafener Kieseltones (Ober-Eozän). Niedersaechs. Geol. Verhandel Jahresber. 27, 41.

Zittel, K.A., 1876. Ueber einige fossile Radiolarien aus der norddeutschen Kreidge. Z. Deut. Geol. Gesell. 28, 75. 



\section{PLATE 1}

Magnification $429 \times$

Figure $1 \quad$ Rhopalosyringium sp. 163-15(CC).

Figure 2 Rhopalosyringium sp. 163-27(CC).

Figure 3 Amphibrachium sp. 163-17(CC).

Figure 4 Lithostrobus sp. 163-15(CC).

Figure 5 Rhopalosyringium sp. 163-23(CC).

Figure 6 Dictyomitra multicostata. 163-27(CC).

Figure $7 \quad$ Theocampe apicata. 163-27(CC).

Figure $8 \quad$ Theoperid gen. and sp. indet. 163-27(CC).

Figure 9 Pseudoaulophacus superbus. 163-27(CC).

Figure 10 Amphipyndax enesseffi. 163-27(CC).

Figure 11 Amphipyndax sp. 163-27(CC).

Figure 12 Pseudoaulophacus sp. P. lenticulatus. 163-27(CC). 

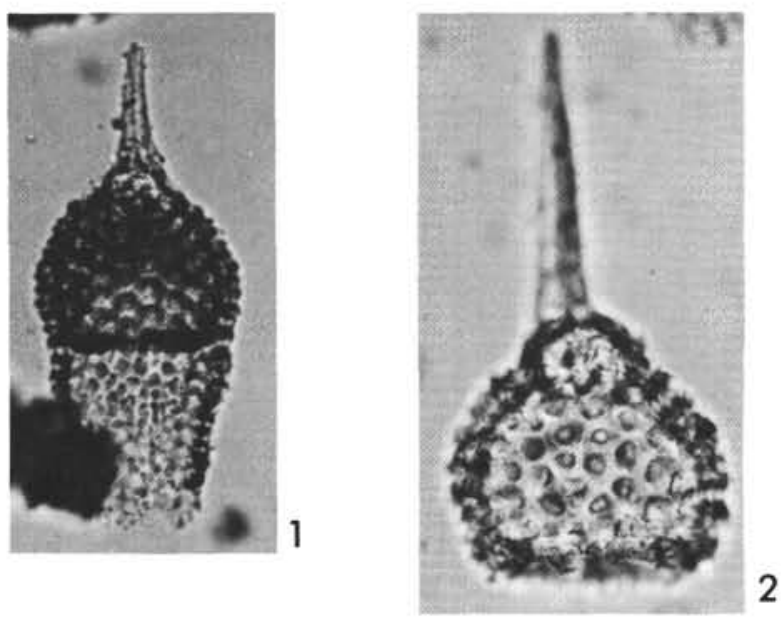

PLATE 1
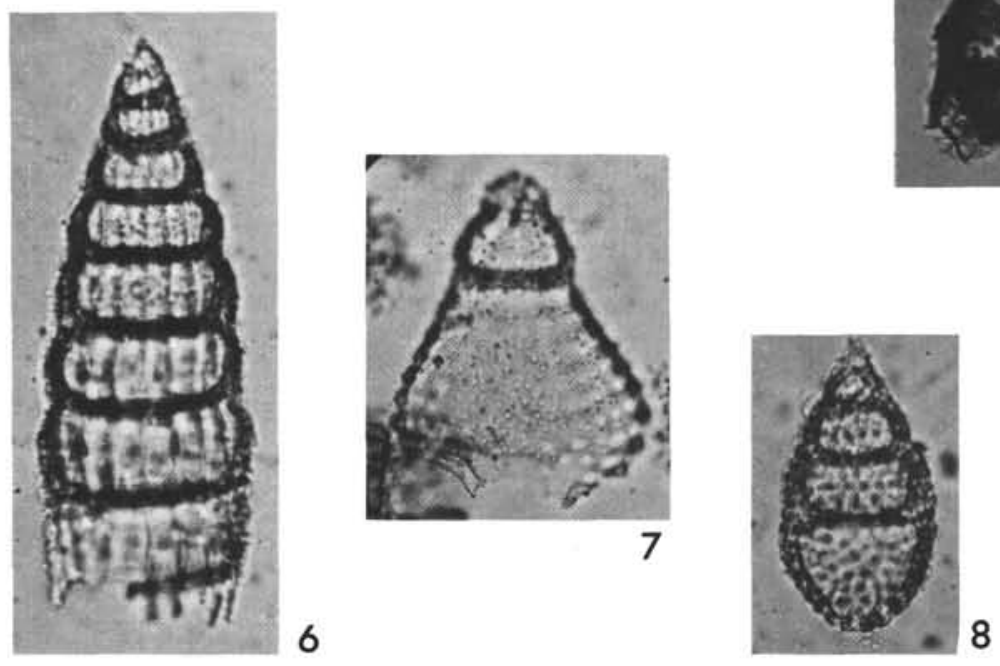
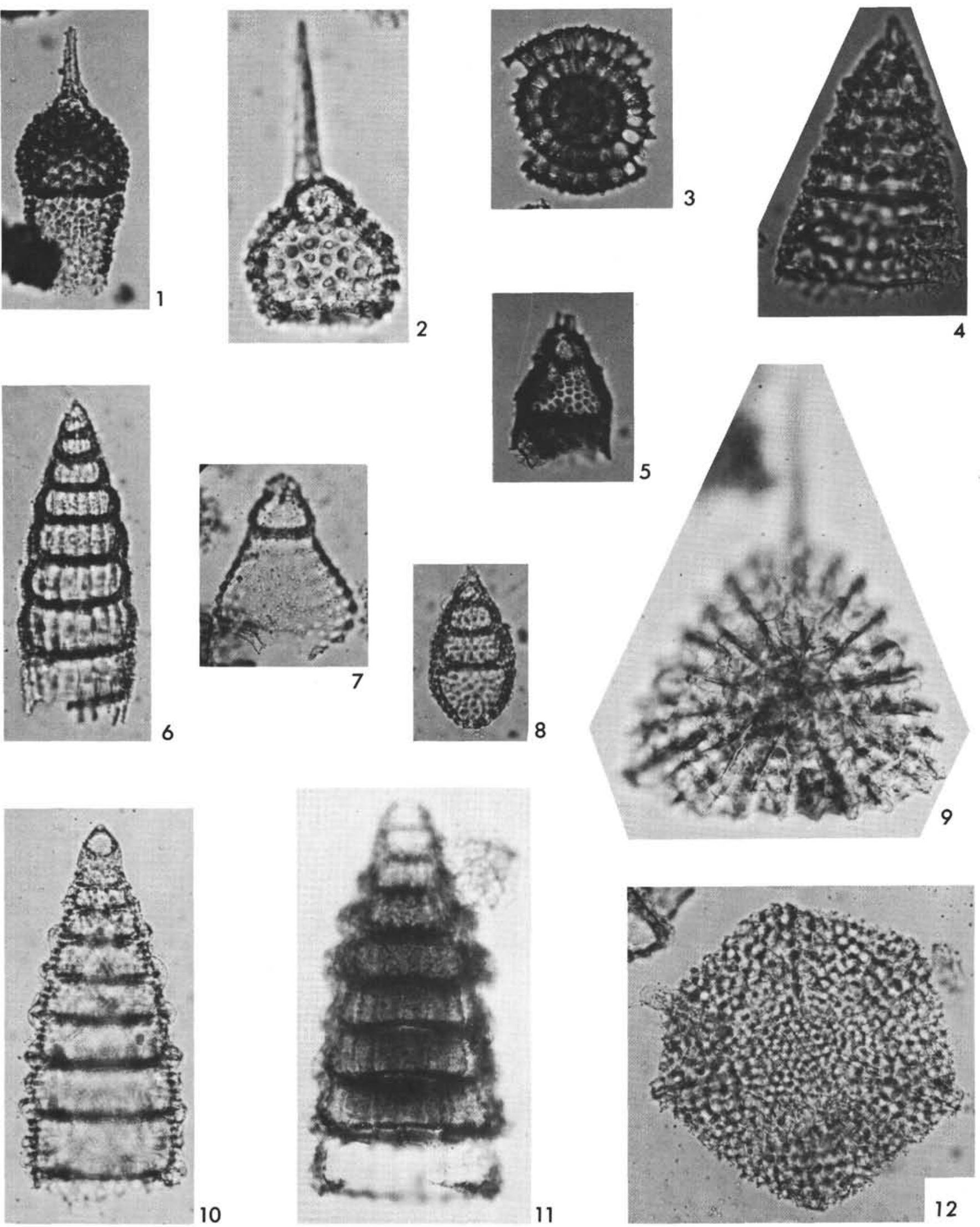
PLATE 2

Magnification $212 \times$

Figure $1 \quad$ Cyclampterium (?) milowi. 162-2-1(140-142 cm).

Figure 2 Theocorys anapographa. 162-9(CC).

Figure $3 \quad$ Lamptonium (?) fabaeforme (?) chaunothorax. 162$15-5(122-125 \mathrm{~cm})$.

Figure 4 Thyrsocyrtis tetracantha. 161A-12-1(51-54 cm).

Figure 5 Thyrsocyrtis tetracantha. 162-5-1(122-124 cm).

Figure $6 \quad$ Lophocyrtis (?) jacchia. 161A-10-1, Top.

Figure $7 \quad$ Thyrsocyrtis triacantha. 162-9(CC).

Figure $8 \quad$ Thyrsocyrtis $\mathrm{cf}$. T. triacantha. 161 A-12-1(51-54 $\mathrm{cm})$. 


\section{PLATE 2}
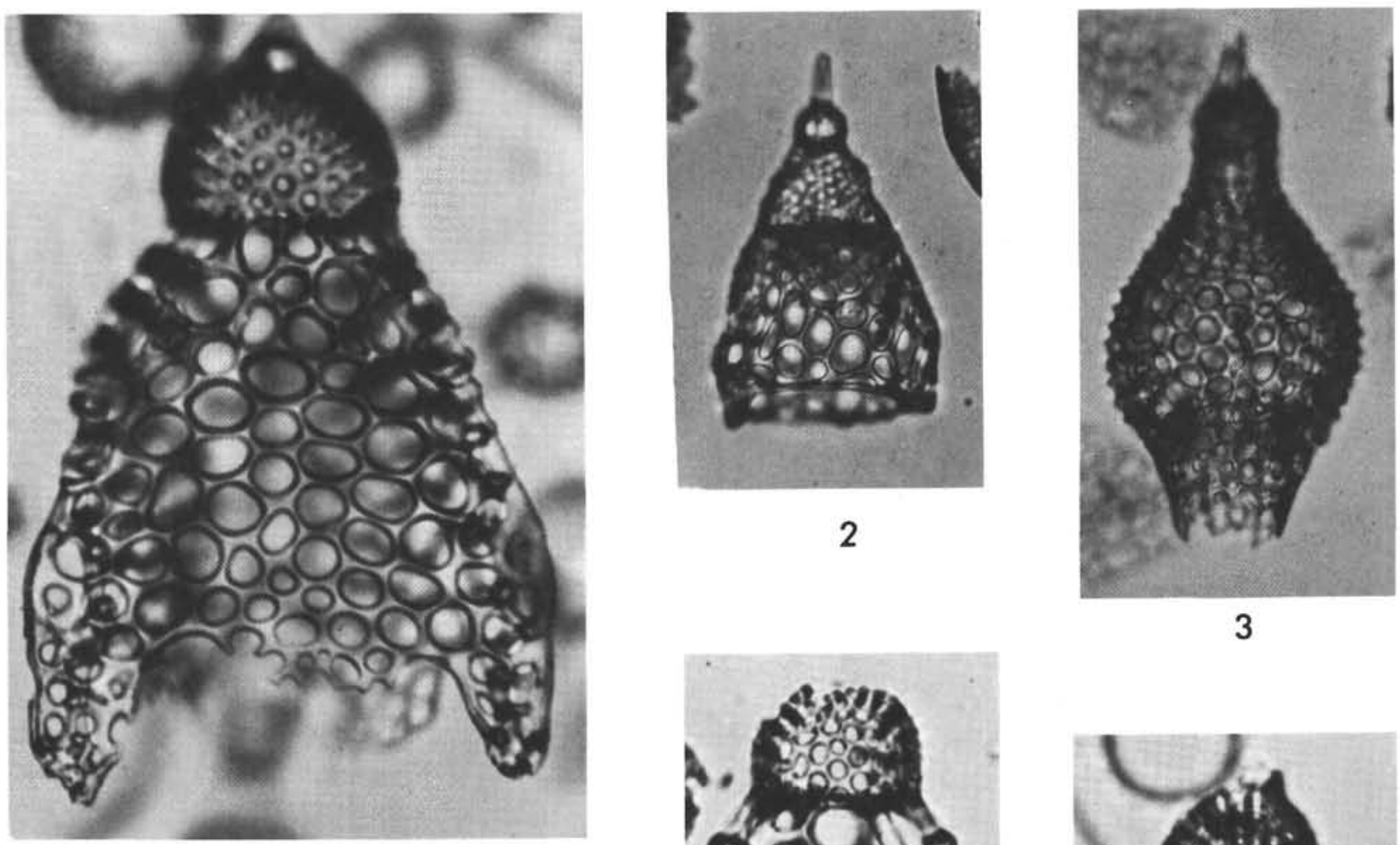

3
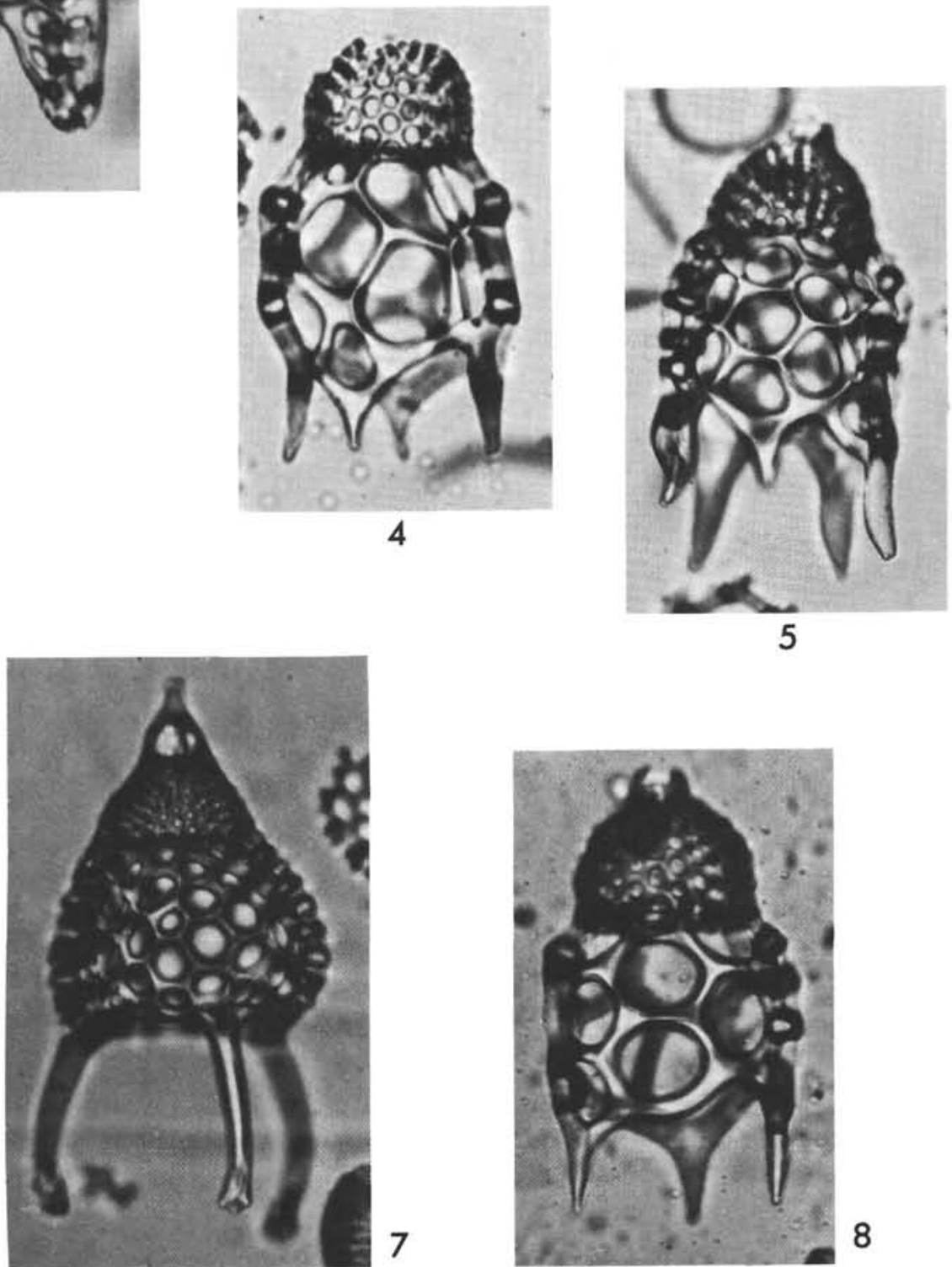
PLATE 3

Magnification $212 \times$

Figure 1 Thyrsocyrtis bromia. 161A-12-1(51-54 cm).

Figure 2 Thyrsocyrtis bromia. 162-5-3(121-124 cm).

Figure 3 Thyrsocyrtis bromia. 161A-10-2(142-144 cm).

Figure $4 \quad$ Thyrsocyrtis bromis. 163-6-3(120-122 cm).

Figure 5 Thyrsocyrtis sp. aff. T. bromia. 161A-12(123-126 $\mathrm{cm})$.

Figure 6 Thyrsocyrtis bromia. 163-6-1(120-122 cm).

Figure 7, $8 \quad$ Thyrsocyrtis sp. 163-6-3(120-122 cm). 


\section{PLATE 3}
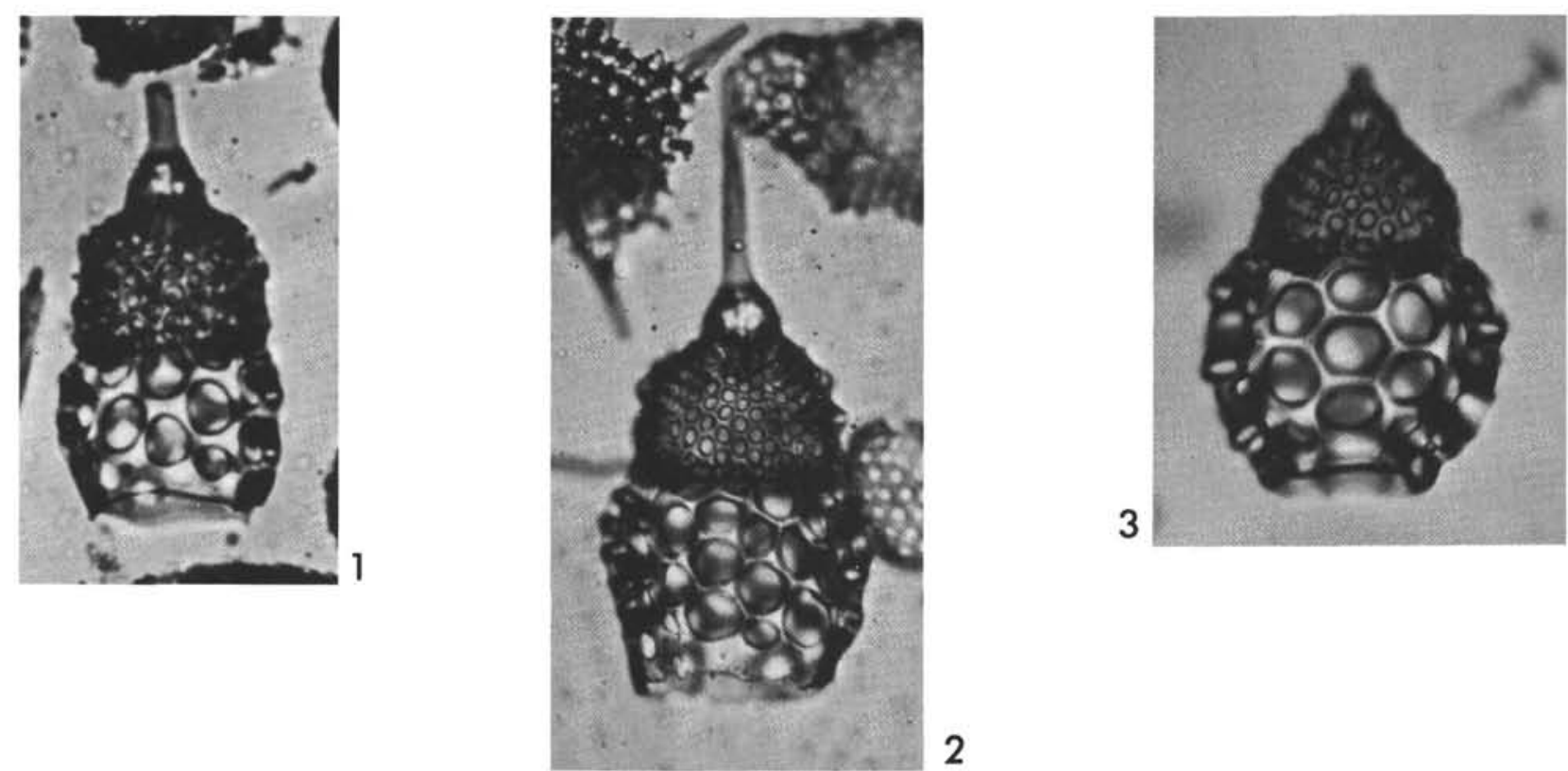

2

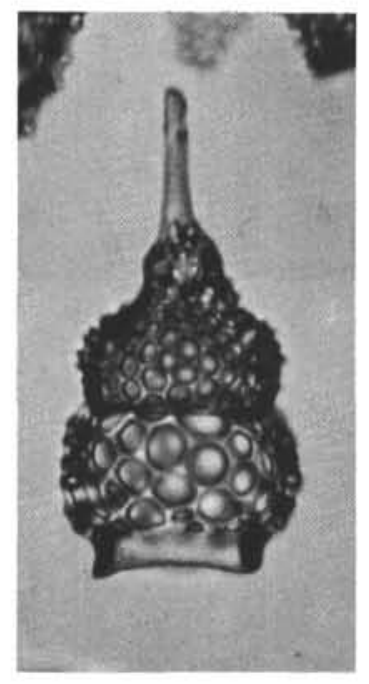

4

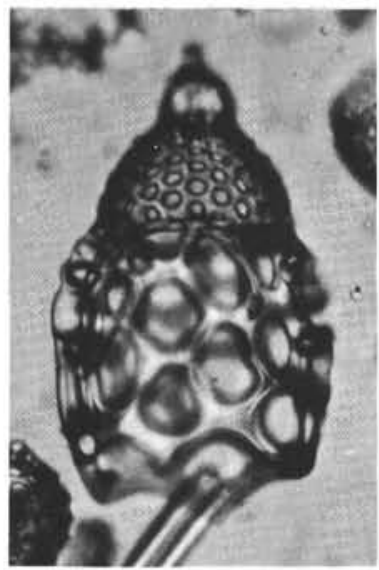

5
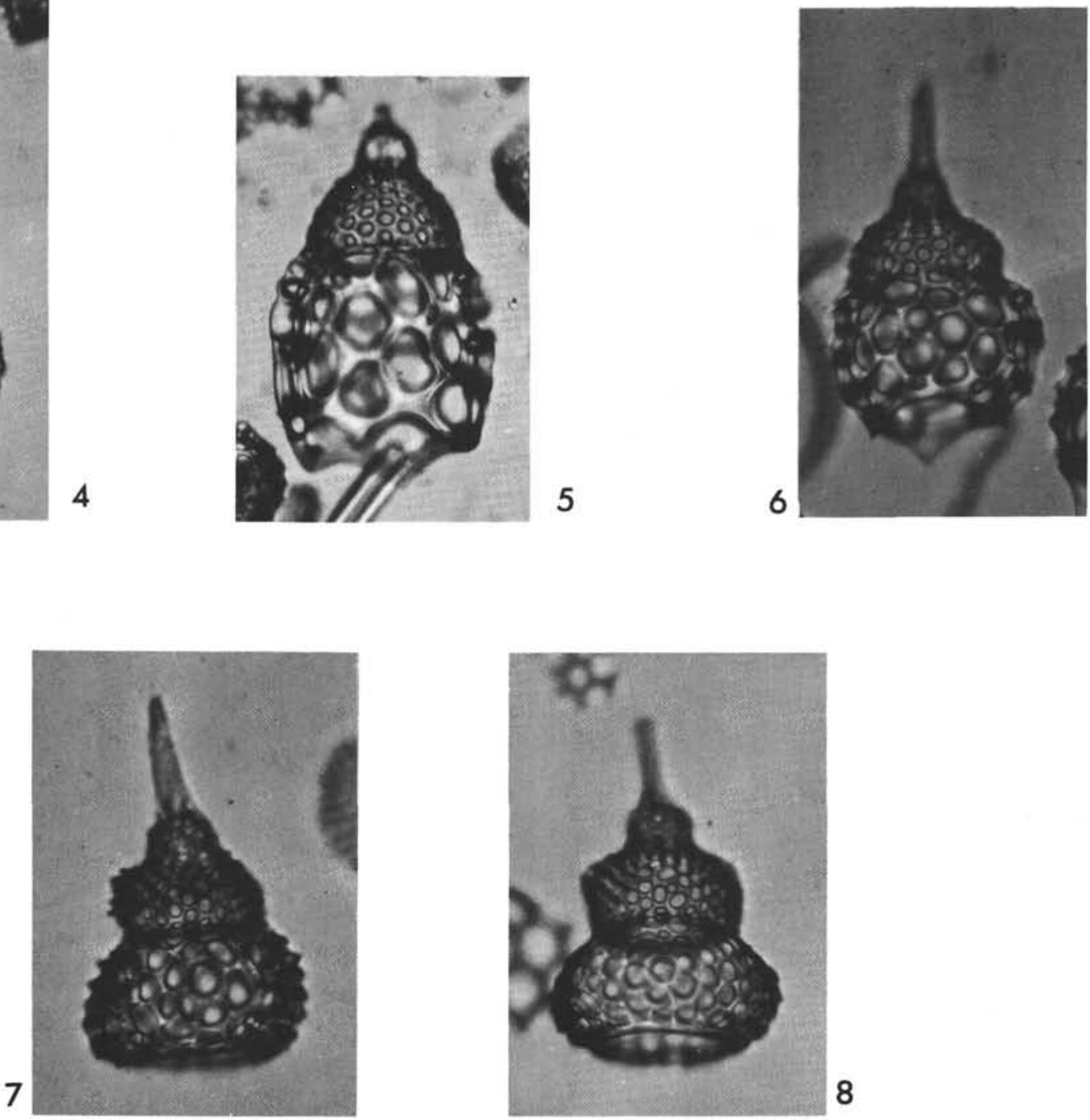
PLATE 4

Magnification $128 \times$

Figure 1 Dorcadospyris triceros. 162-3-1(124-126 cm).

Figure 2 Dorcadospyris pseudopapilio. 162-3-1(124-126 cm).

Figure 3 Dorcadospyris pseudopapilio. 161A-8-3(124-126 $\mathrm{cm})$.

Figure 4 Dorcadospyris quadripes. 161A-6-3(125-128 cm).

Figure 5 Dorcadospyris quadripes. 161A-3-1(127-129 cm).

Figure 6 Dorcadospyris circulus. 161-7-5(28-30 cm).

Figure 7 Dorcadospyris circulus. 161-11-3(114-116 cm).

Figure 8 Dorcadospyris spinosa. 161A-3-1(127-129 cm).

Figure 9 Dorcadospyris spinosa. 161A-3(CC).

Figure 10 Dorcadospyris riedeli. 161-9(CC). 
PLATE 4
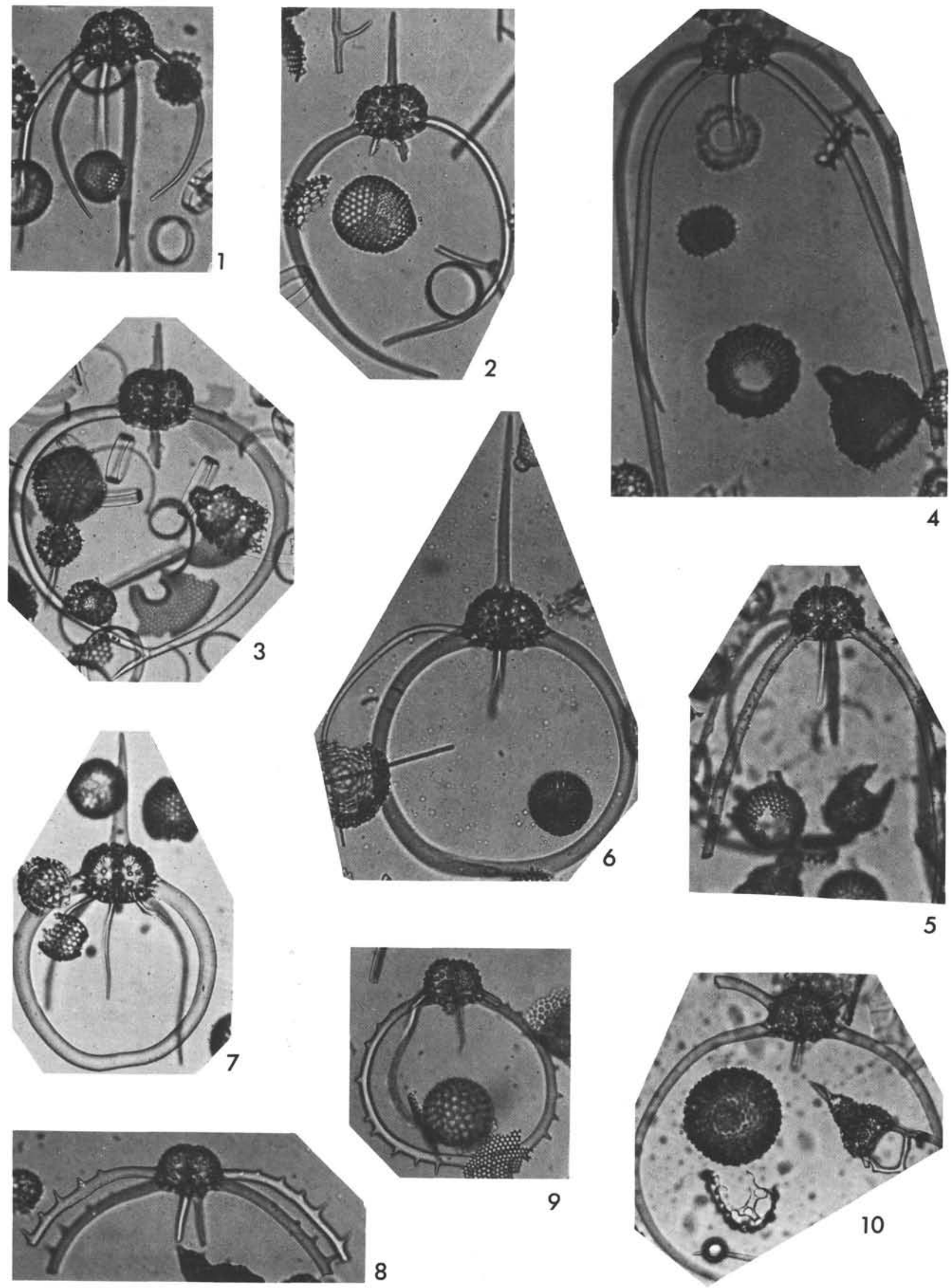
PLATE 5

Magnification $212 \times$

Figure 1 Cannartus sp. A. 161-4(CC).

Figure 2 Cannartus sp. A. 161-1-2(139-142 cm).

Figure 3 Cannartus tubarius. 161-4(CC).

Figure 4 Cannartus tubarius. 159-4-3(64-67 cm).

Figure 5 Cannartus prismaticus. 160-5-4(124-126 cm).

Figure 6 Centrobotrys gravida. 161A-7-1(102-105 cm).

Figure 7 Lithocyclia angustum. 161A-9-1(124-126 cm).

Figure $8 \quad$ Lithocyclia angustum. 161-11-3(114-116 cm).

Figure 9 Lithocyclia crux. 161A-6-1(110-112 cm).

Figure 10 Theocyrtis annosa. 161A-1-1(56-59 cm). 


\section{PLATE 5}
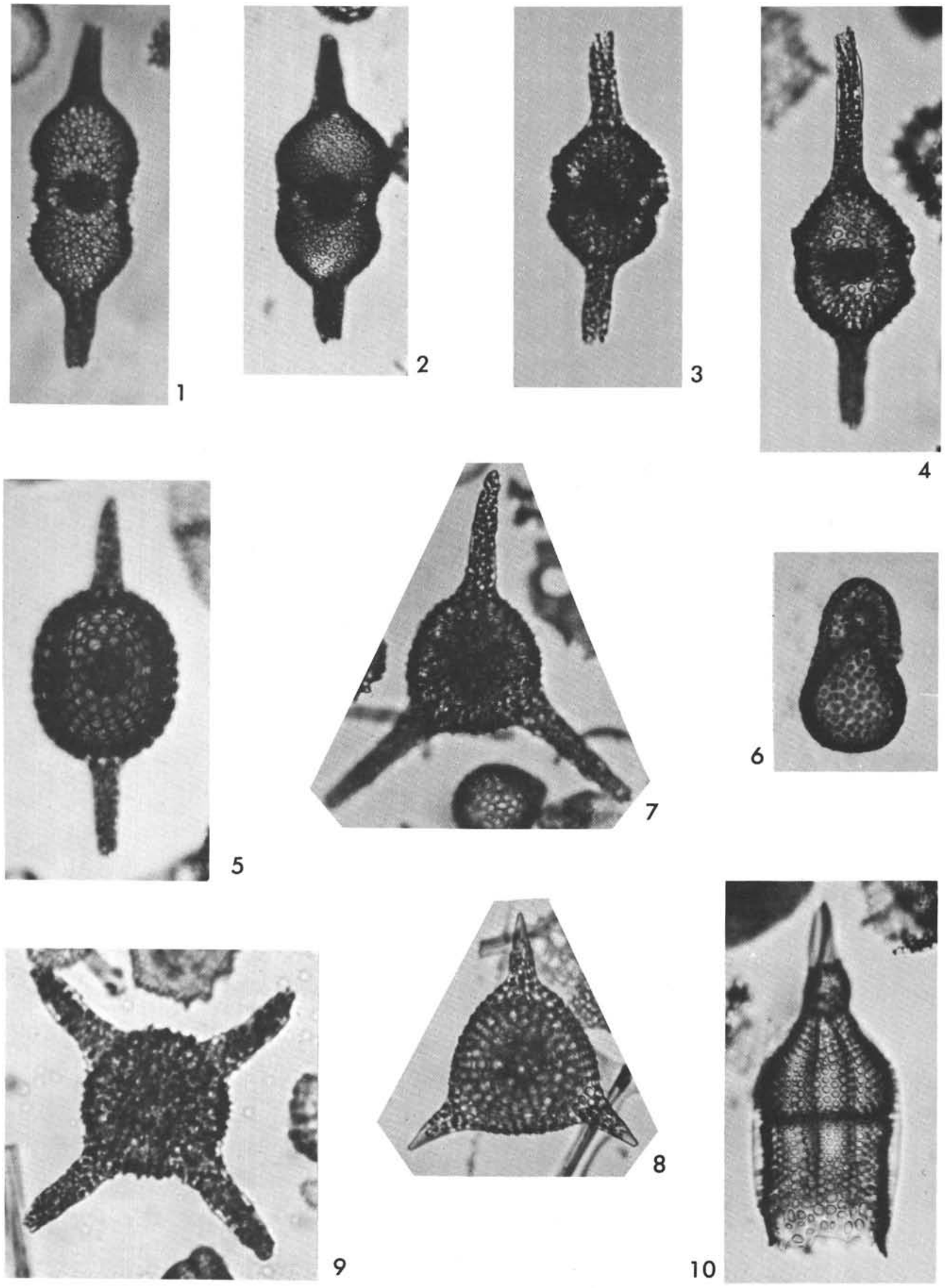


\section{PLATE 6}

Magnification, Figure 1, 212×; Figures 2-9, 128×.

Figure 1 Lychnocanoma bipes. 160-5-1(128-140 cm).

Figure 2 Dorcadospyris simplex. 160-3-5(133-136 cm).

Figure 3 Dorcadospyris simplex. 160-5-4(124-126 cm).

Figure 4 Dorcadospyris sp. aff. D. simplex. 160-5-4(124-126 $\mathrm{cm})$.

Figure 5 Dorcadospyris ateuchus. 160-6-3(124-126 cm).

Figure 6 Dorcadospyris papilio. 160-5-5(114-116 cm).

Figure 7 Dorcadospyris forcipata. 160-3-5(133-136 cm).

Figure 8 Dorcadospyris praeforcipata. 160-6-3(124-126 cm).

Figure 9 Dorcadospyris alata. 158-3(CC). 
RADIOLARIAN STRATIGRAPHY

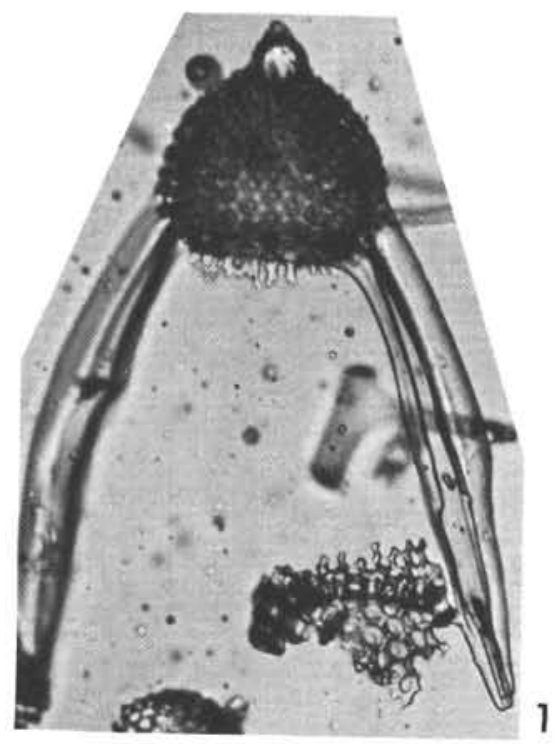

PLATE 6
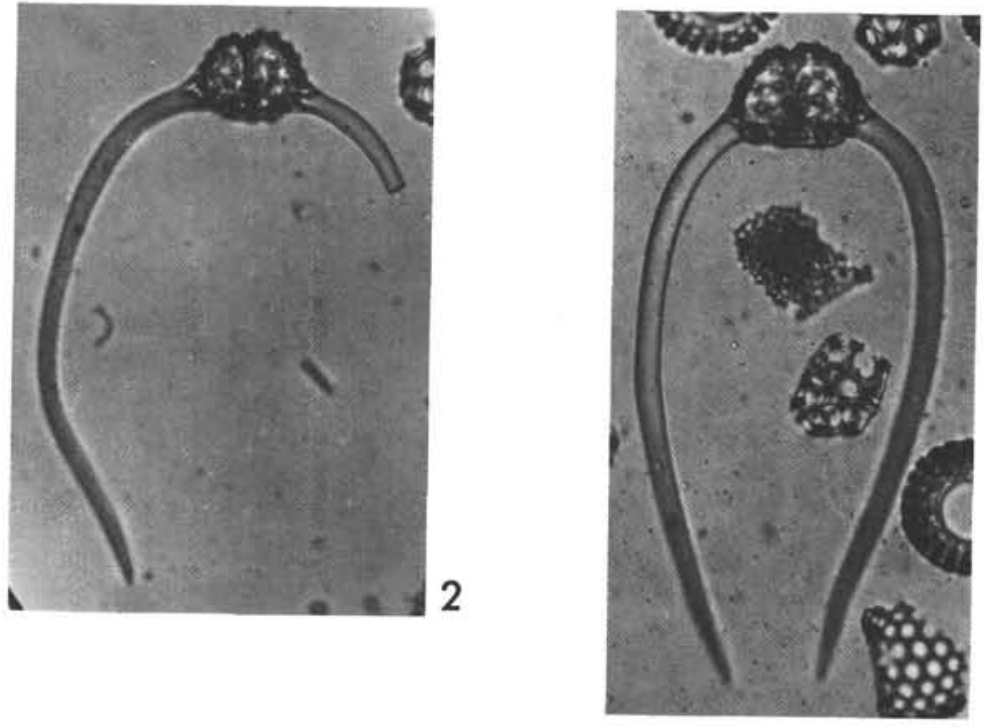

3

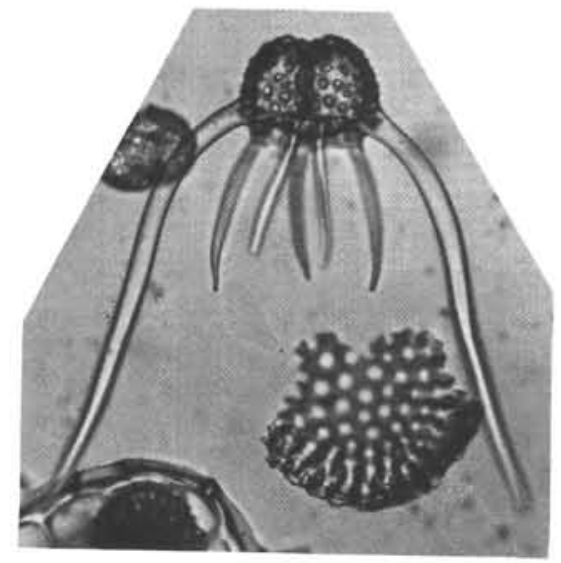

5
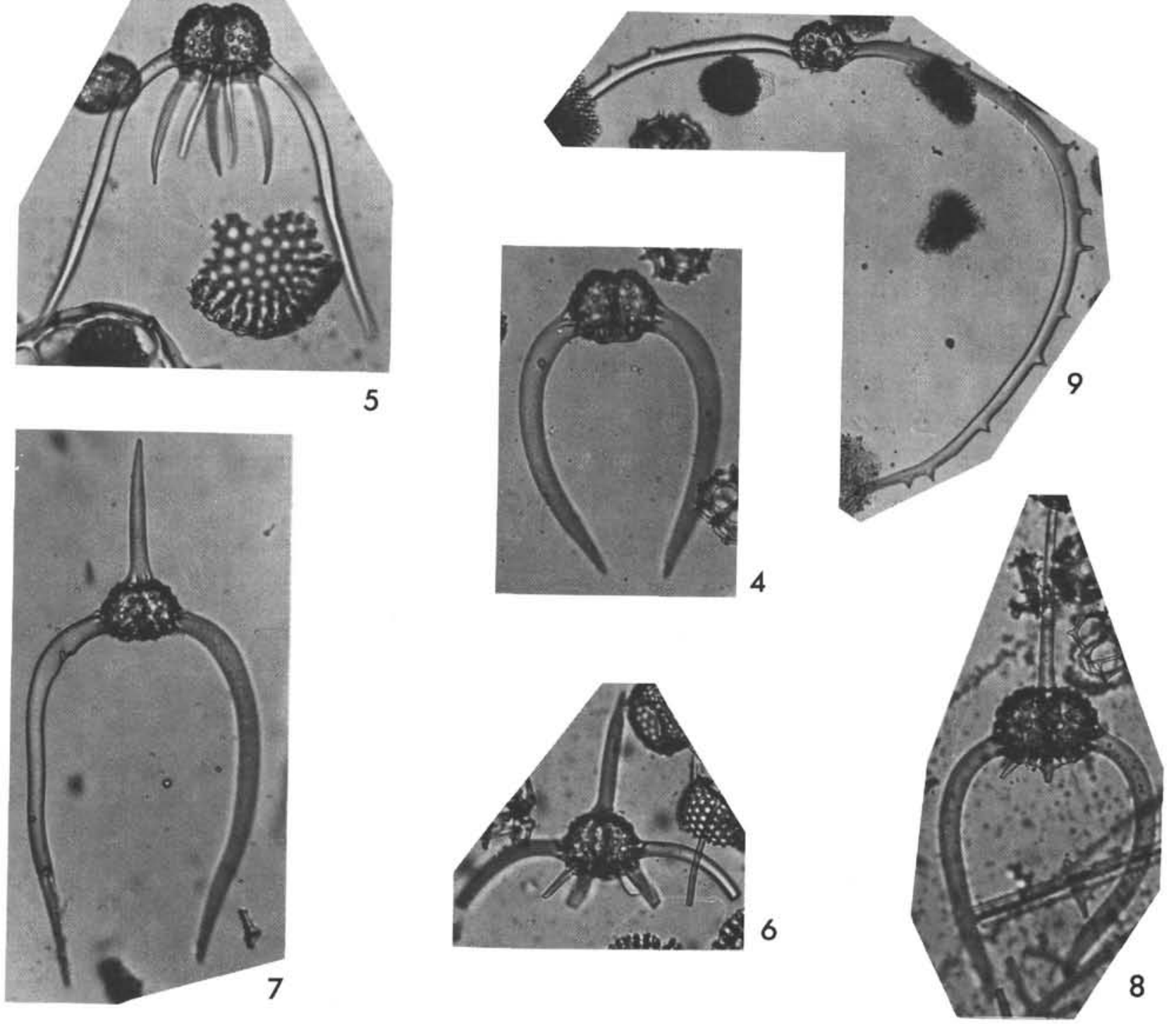


\section{PLATE 7}

Magnification $212 \times$

Figure 1 Calocycletta parva. 161A-2-3(124-126 cm).

Figure 2 Calocycletta parva. 161-11-3(114-116 cm).

Figure 3 Calocycletta $\mathrm{cf}$. C. parva. 161A-2-3(124-126 cm).

Figure 4 Calocycletta robusta. 161-3-1(123-126 cm).

Figure 5 Calocycletta serrata. 161-1-2(139-142 cm).

Figure $6 \quad$ Calocycletta virginis. 159-4-3(64-67 cm).

Figure 7 Calocycletta virginis. 161-1-2(139-142 cm),

Figure $8 \quad$ Calocycletta costata. 159-4-3(64-67 cm).

Figure $9 \quad$ Calocycletta caepa. 158-33(CC). 


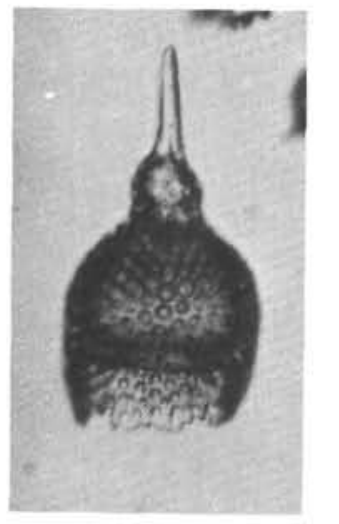

PLATE 7
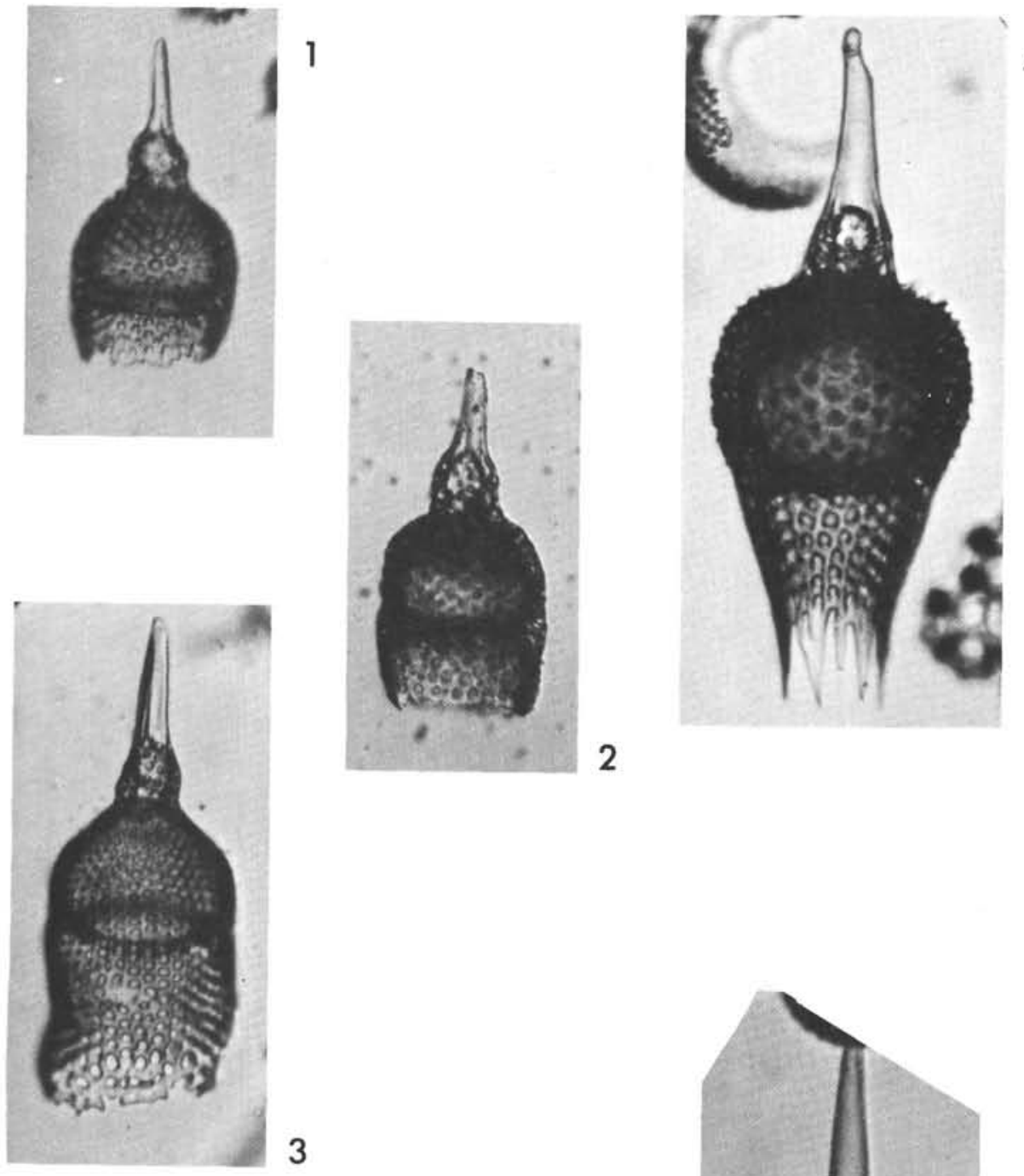

4
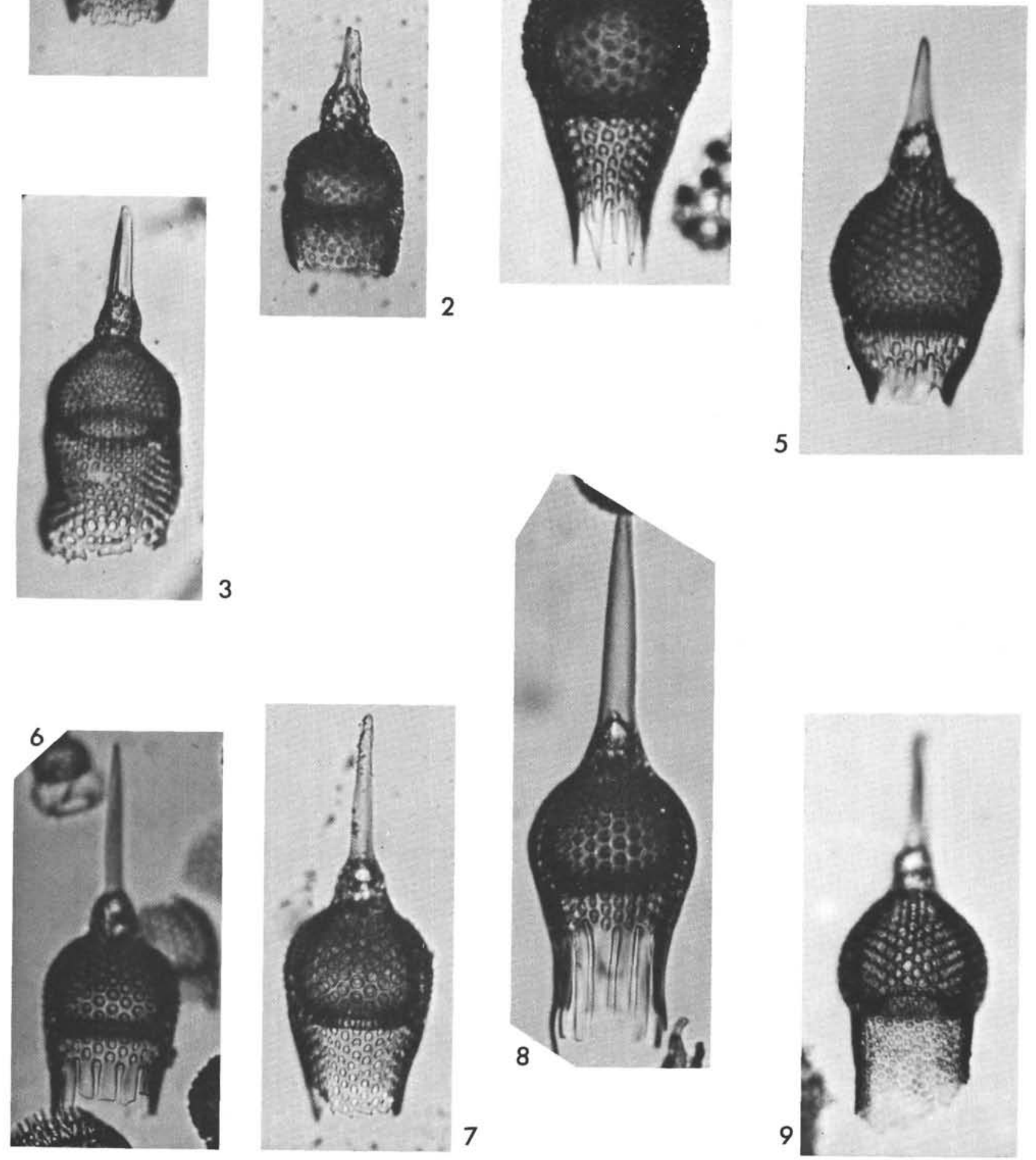
PLATE 8

Magnification $212 \times$

Figure $1 \quad$ Cannartus violina. 159-4-3(64-67 cm).

Figure 2 Cannartus mammiferus. 159-4-1(124-126 cm).

Figure 3 Cannartus mammiferus. 159-4-3(64-67 cm).

Figure 4 Cannartus laticonus. 158-34(CC).

Figure $5 \quad$ Cannartus (?) petterssoni. 158-32-3(74-76 cm).

Figure 6 Cannartus laticonus. 158-33-1(108-110 cm).

Figure 7 Ommatartus antepenultimus. 158-22-2(124-126 $\mathrm{cm})$.

Figure 8 Ommatartus antepenultimus. 158-24-2(124-127 $\mathrm{cm})$.

Figure 9 Cannartus (?) petterssoni. 158-31-1(14-16 cm).

Figure 10, 11 Cannartus (?) petterssoni. 158-24-2(124-127 cm).

Figure 12 Ommatartus hughesi. 158-22-2(124-126 cm). 
PLATE 8
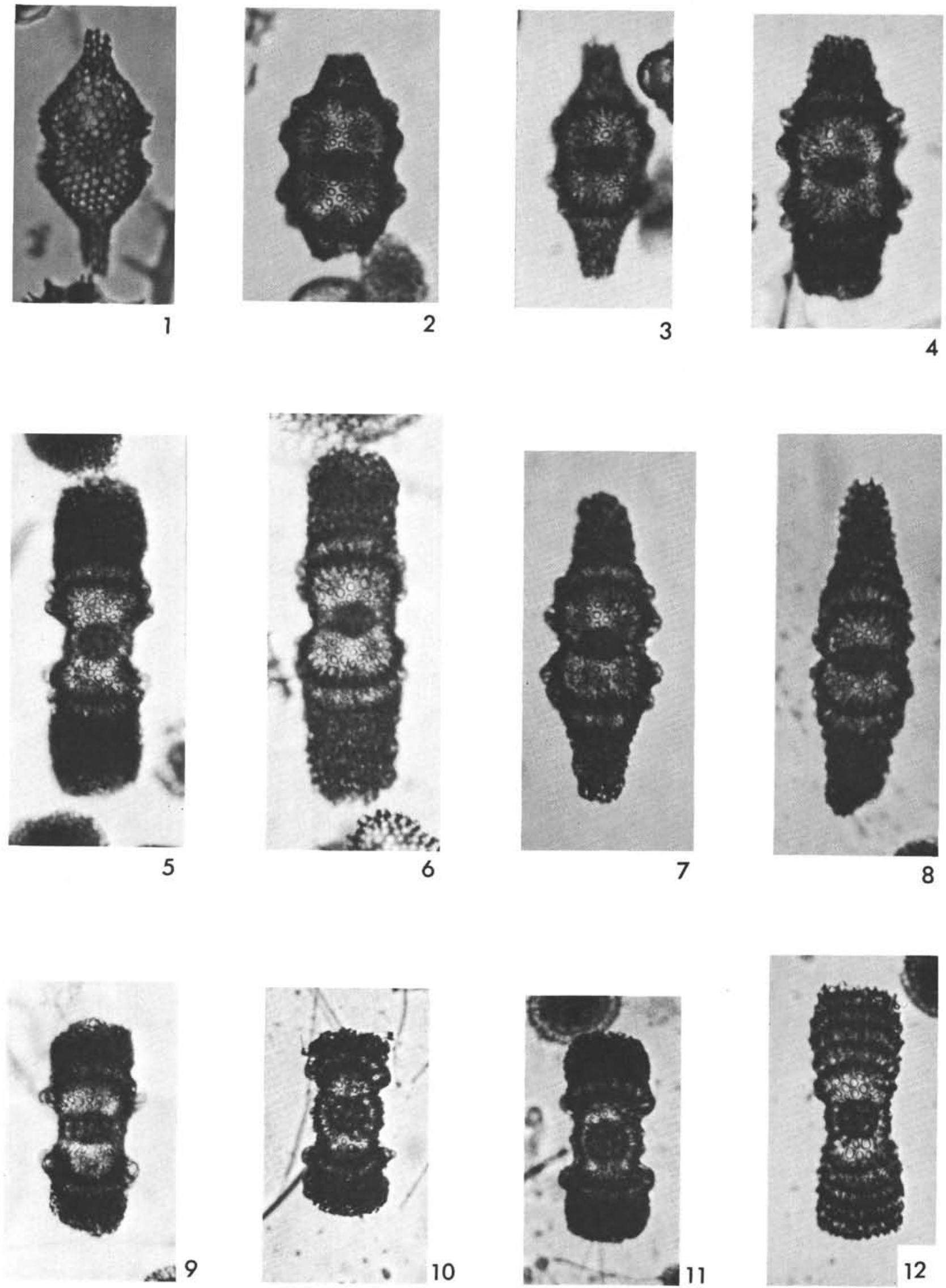


\section{PLATE 9}

Magnification $212 \times$

Figure 1 Stichocorys delmontensis. 158-16-4(74-77 cm).

Figure 2 Stichocorys peregrina. 158-10-3(124-126 cm).

Figure 3 Stichocorys peregrina. 158-13-4(73-76 cm).

Figure 4 Spongaster pentas. 158-9-1(134-136 cm).

Figure $5 \quad$ Cyrtocapsella japonica. 158-33-1(108-110 cm).

Figure $6 \quad$ Lithopera bacca. 158-9-1(134-136 cm).

Figure 7 Ommatartus penultimus. 158-15-2(69-71 cm).

Figure $8 \quad$ Ommatartus penultimus. $158-13-2(73-76 \mathrm{~cm})$.

Figure $9 \quad$ Lithopera neotera. 158-32-3(74-76 cm).

Figure $10 \quad$ Lithopera neotera. 158-25-4(105-108 cm).

Figure $11 \quad$ Lithopera renzae. 158-34-1(74-76 cm).

Figure 12 Lithopera renzae. 158-33(CC).

Figure 13 Lithopera baueri. 158-33-1(108-110 cm).

Figure $14 \quad$ Lithopera thornburgi. 158-32-3(74-76 cm). 
PLATE 9
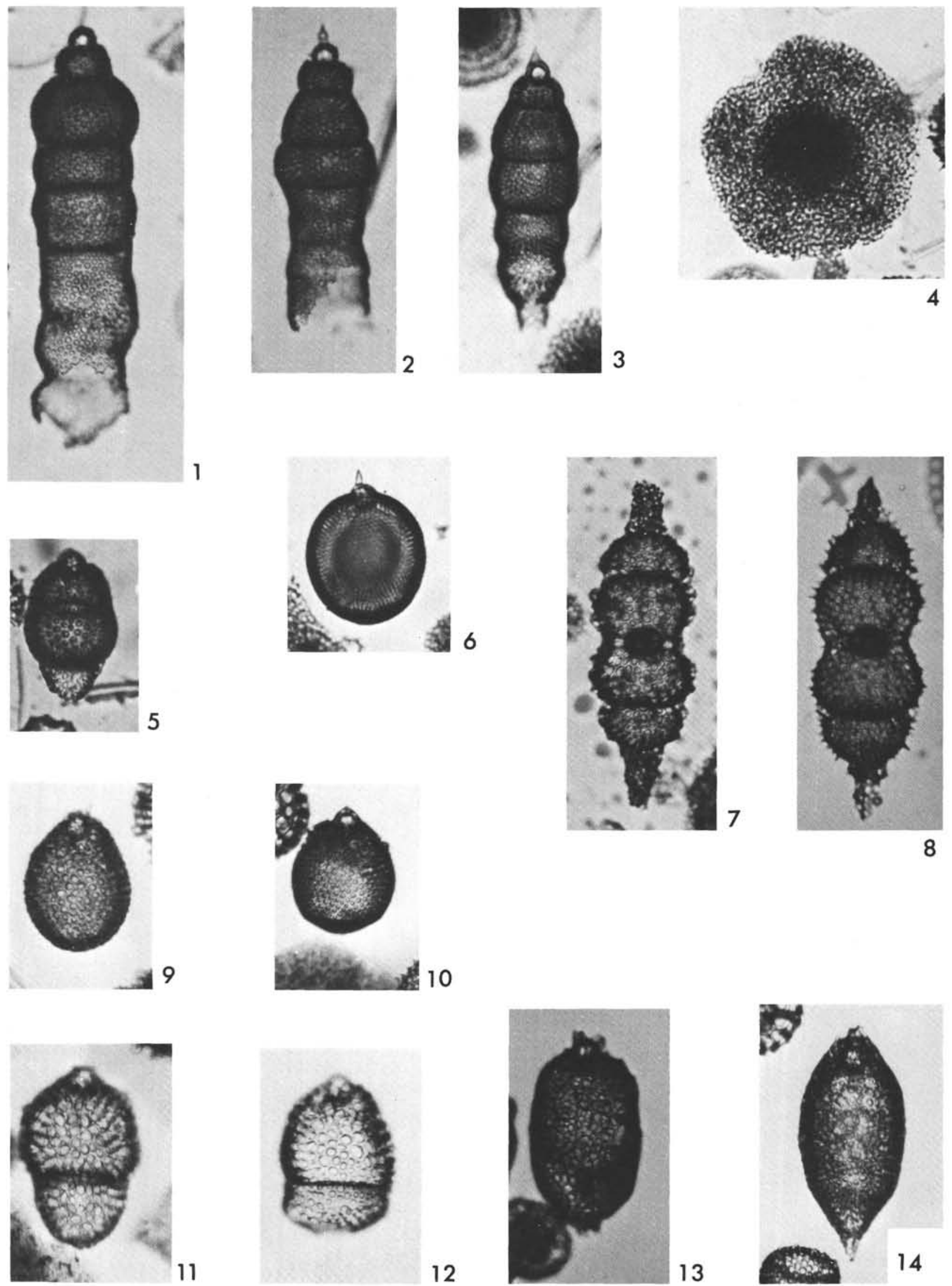
PLATE 10

Magnification $212 \times$

Figure 1 Collosphaera tuberosa. 156-1-1(134-136 cm).

Figure 2 Collosphaera tuberosa. 157A-1-5(123-125 cm).

Figure 3 Buccinosphaera invaginato TRI-HF-4, Top.

Figure 4 Spongaster tetras 156-1-1(112-114 cm).

Figure 5 Anthocyrtidium angulare. 157-8-3(126-128 cm).

Figure $6 \quad$ Stylatractus universus. 158-9-1(124-136 cm).

Figure $7 \quad$ Stylatractus universus. 157-3(CC).

Figure 8 Theocorythium trachelium trachelium. 156-1(CC).

Figure 9 Theocorythium trachelium. 157-3(CC).

Figure 10 Amphirhopalum ypsilon. 157A-2-1(142-144 cm).

Figure 11 Theocorythium vetulum. 157-8-3(126-128 cm).

Figure 12 Theocorythium vetulum. 157-7-5(125-127 cm). 
PLATE 10
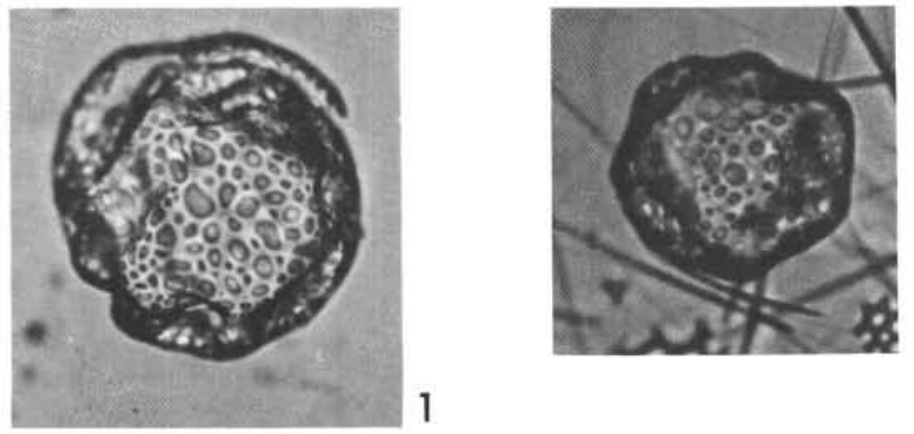

2
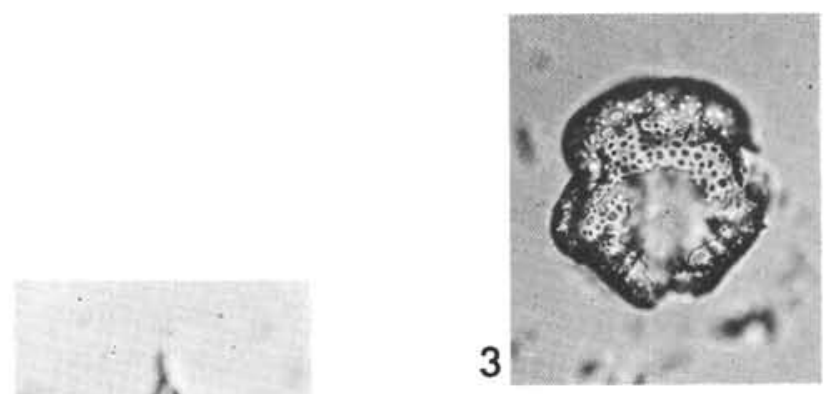

5
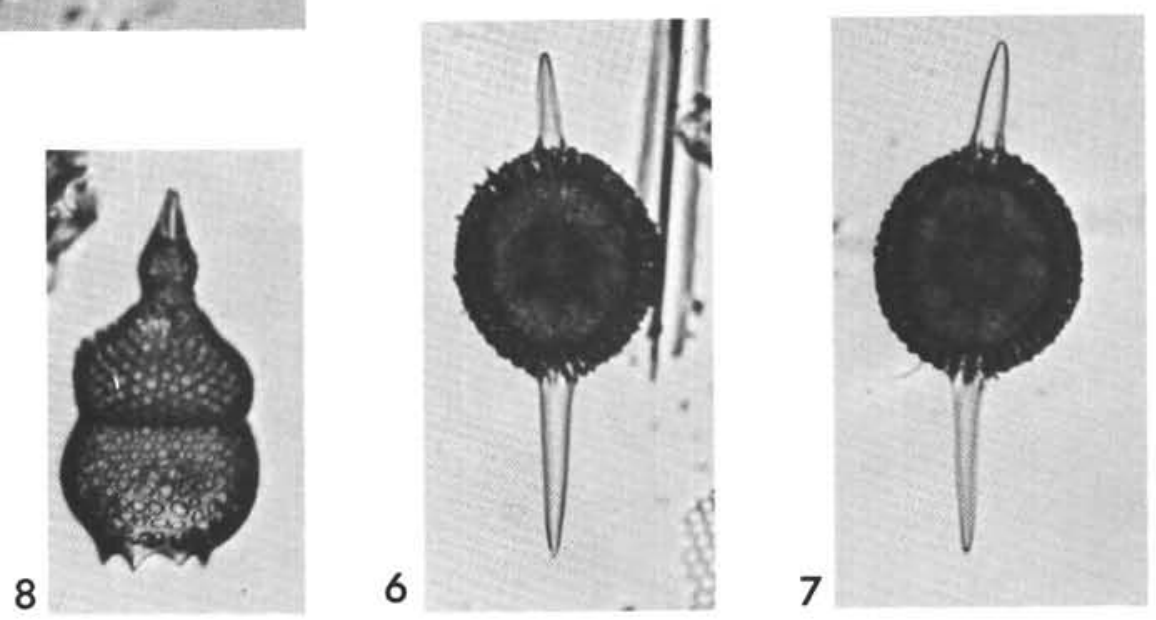

10

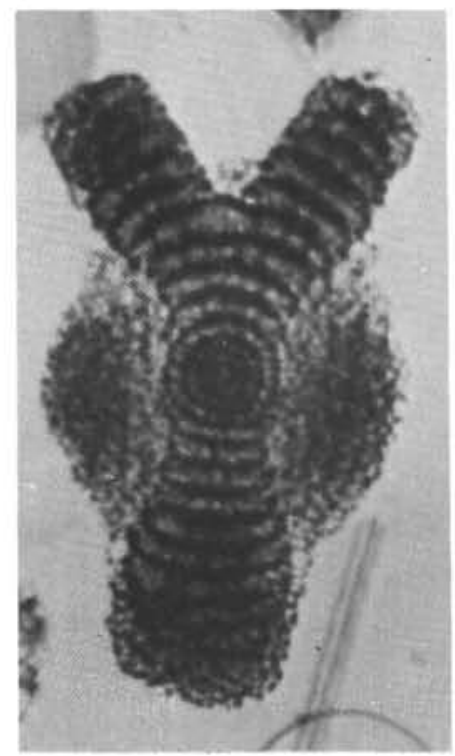

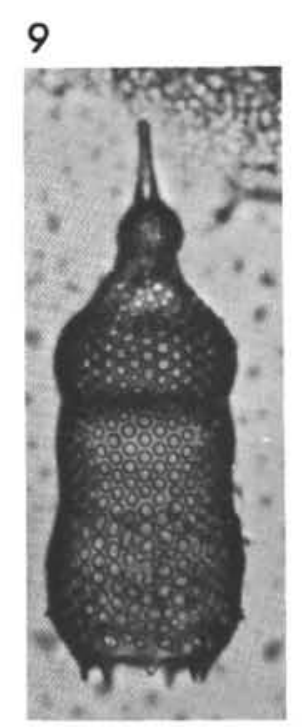

\section{2}

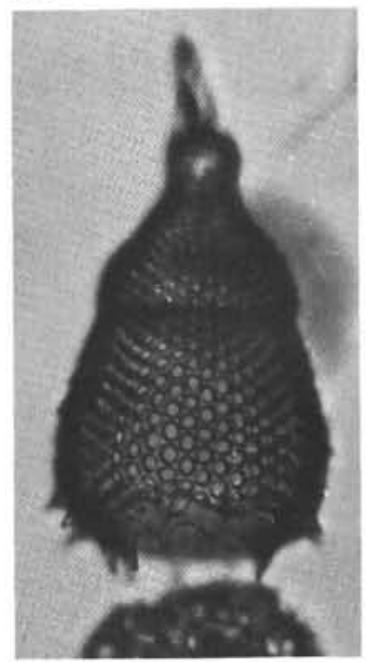

